\title{
CRUZAMENTOS DIALÉLICOS ENTRE LINHAS DE MILHO CONTRASTANTES NO USO DO NITROGÊNIO
}

\section{LEONARDO OLIVEIRA MEDICI}

Tese apresentada à Escola Superior de Agricultura "Luiz de Queiroz", Universidade de São Paulo, para obtenção do título de Doutor em Agronomia, Área de concentração: Genética e Melhoramento de Plantas.

P I R A C I C A B A

Estado de São Paulo - Brasil

Janeiro - 2003 


\section{CRUZAMENTOS DIALÉLICOS ENTRE LINHAS DE MILHO CONTRASTANTES NO USO DO NITROGÊNIO}

\section{LEONARDO OLIVEIRA MEDICI}

Engenheiro Agrônomo

Orientador: Prof. Dr. RICARDO ANTUNES DE AZEVEDO

Tese apresentada à Escola Superior de Agricultura
"Luiz de Queiroz", Universidade de São Paulo, para
obtenção do título de Doutor em Agronomia, Área de
concentração: Genética e Melhoramento de Plantas.

P I R A C I C A B A

Estado de São Paulo - Brasil

Janeiro - 2003 


\section{Dados Internacionais de Catalogação na Publicação (CIP) DIVISÃO DE BIBLIOTECA E DOCUMENTAÇÃO - ESALQ/USP}

\section{Medici, Leonardo Oliveira}

Cruzamentos dia lélic os entre linhas de milho contrastantes no uso do nitrogênio / Leonardo Oliveira Medici. - - Piracicaba, 2003.

$88 \mathrm{p}$. : il.

Tese (doutorado) - Esc ola Superior de Agric ultura Luiz de Queiroz, 2003. Bibliografia.

1. Cruza mento vegetal 2. Milho 3. Nitrogênio 4. Nutrição vegetal I. Título

CDD 633.15

"Permitida a cópia total ou parcial deste documento, desde que citada a fonte - $\mathrm{O}$ autor" 
À minha mulher Natalie e aos meus filhos Maria e Francisco, que são a alegria da minha vida, dedico. 


\section{AGRADECIMENTOS}

Ao povo brasileiro, do qual serei sempre devedor, por todo ensino gratuito recebido.

À Natalie Vidart Badia por todo apoio e incentivo e por me fazer sentir suficientemente capaz para este serviço.

Aos meus pais, Ewaldo e Neli, e irmãos, Antônio e Sebastião, por toda a torcida.

Ao Prof. Ricardo Antunes de Azevedo por toda colaboração, incentivo e oportunidades generosamente concedidas.

Ao Prof. Peter John Lea e ao Dr. Richard John Smith por toda a atenção dispensada e também aos companheiros do laboratório de Lancaster, Dia, Sophie, Tulene, Guy, Jaz, Gaz, Sue, Eugene, Mark, Mardika e Paul.

Ao Prof. Maurício Ballesteiro Pereira, pela colaboração e iniciativa de trabalhar com Genética e Fisiologia Vegetal.

Aos funcionários da ESALQ, principalmente ao Alexandre de Camargo Campos, ao José Monteiro, ao Cláudio Roberto Segatelli, e ao Márcio Araújo Silva, por toda boa vontade e empenho exemplares na execução dos experimentos, e também ao Carlos Roberto Macedônio, pelas rápidas soluções em informática.

Aos colegas de laboratório Salete, Rico, Renato, Guilherme, Patrícia, Vanderlei, Ângela, Alejandro, Andréia, José Carmezini, Georgia, Leandro e Liliane pela colaboração e pelo sempre amigável compartilhamento de conhecimentos e espaço de trabalho.

Ao Departamento de Ciências Fisiológicas da UFRRJ, especialmente à Prof. Nidia Majerowicz e ao Prof. Luís Carlos Reis, pela concessão e pelo apoio ao afastamento integral para cursar o doutorado.

À ESALQ/USP por todo apoio ao trabalho e, principalmente, pela assistência à minha família. 
Aos Professores deste programa, especialmente ao Isaías Olívio Geraldi e ao Cláudio Lopes Souza Júnior, que ensinam ao mesmo tempo Genética e Didática.

Ao Dr. Luciano Nass pela disponibilização de sementes de milho.

Aos Professores Ricardo Ferraz de Oliveira e Carlos Labate pelo empréstimo de equipamentos.

À FAPESP (Proc. 98/12461-0) pelos recursos financeiros concedidos.

À CAPES e ao Programa Institucional de Capacitação Docente e Técnica da UFRRJ pela bolsa de estudos.

Ao CNPq pela bolsa de doutorado sandwich. 


\section{SUMÁRIO}

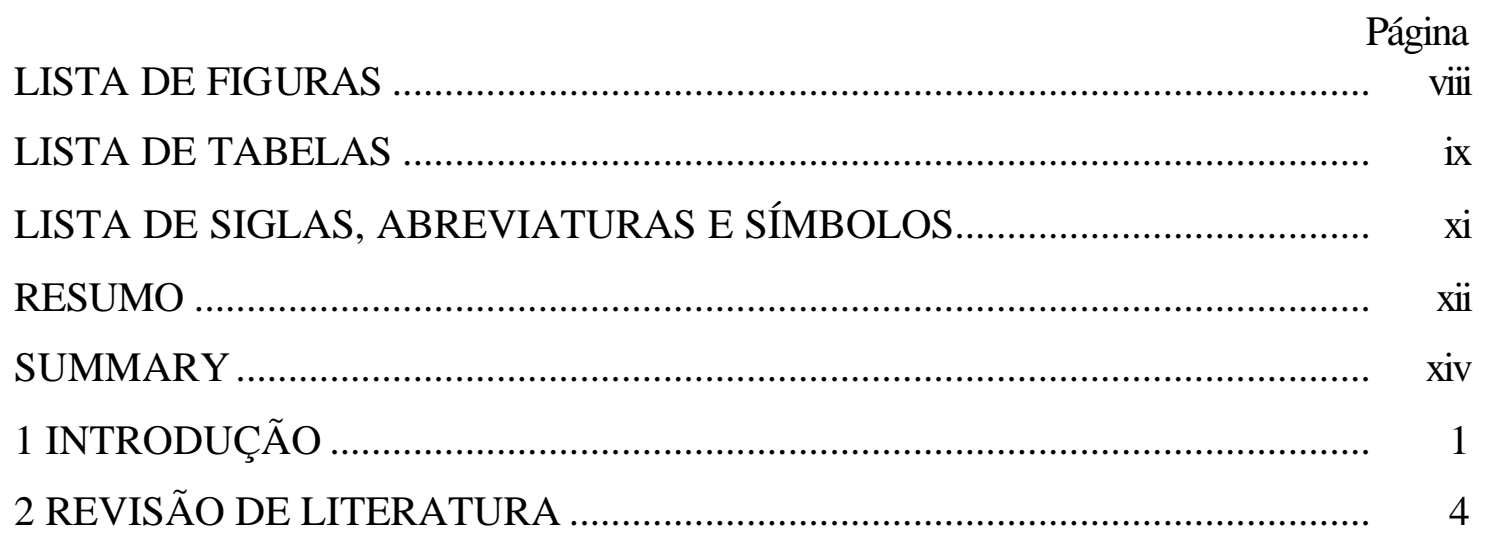

2.1 Conceitos sobre eficiência no uso do nitrogênio ................................................. 4

2.2 Seleção em ambientes com e sem deficiência de nitrogênio ............................... 7

2.3 Fisiologia e genética da eficiência no uso do nitrogênio ..................................... 9

2.4 Metabolismo da assimilação do nitrogênio ......................................................... 20

2.5 Deficiência de nitrogênio e fotoinibição ............................................................. 24

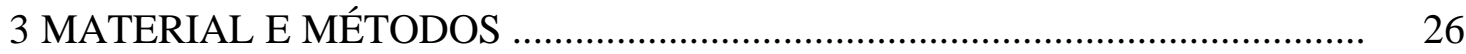

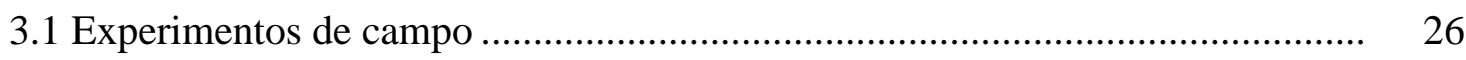

3.1.1 Experimento 1 ...................................................................................... 26

3.1.2 Experimento 2 ........................................................................... 28

3.2 Experimentos em casa de vegetação …………………………………........ 29

3.2.1 Experimento 1 ................................................................................... 29

3.2.2 Experimento 2 …......................................................................... 33

3.3 Experimento em sala de crescimento ………………................................... 34

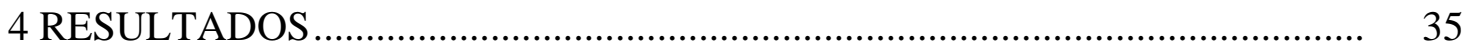

4.1 Experimentos de campo ...................................................................... 35

4.1.1 Comparação entre as linhas avaliadas nos experimentos 1 e 2 ……………... 35

4.1.2 Análise dialélica ...................................................................................... 40 
4.2 Experimentos em casa de ve getação ............................................................ 46

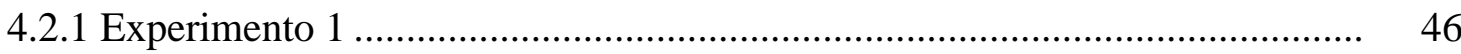

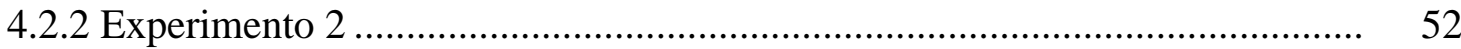

4.3 Experimento em sala de crescimento ...................................................... 55

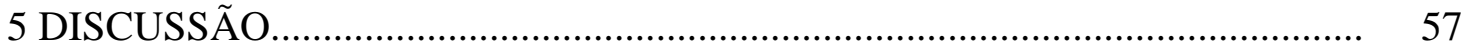

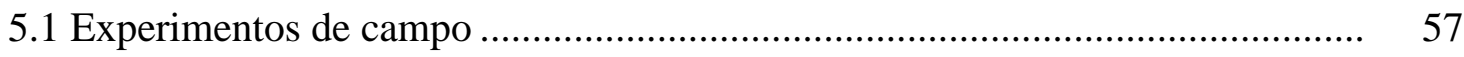

5.1.1 Comparação entre as linhas avaliadas nos experimentos 1 e 2 ..................... 57

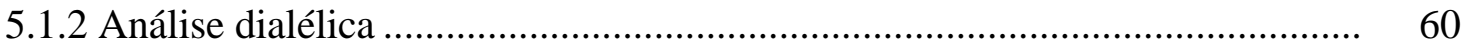

5.2 Experimentos em casa de vegetação e em sala de crescimento ........................ 66

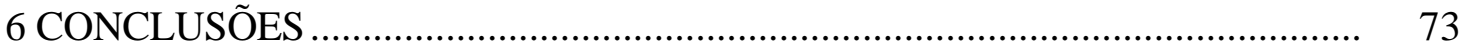

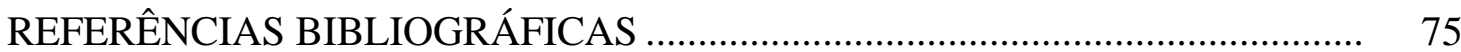




\section{LISTA DE FIGURAS}

1 Herdabilidades e congina

1 Herdabilidades e correlações genéticas de variáveis secundárias com a produtividade em 90 ensaios de milho do CIMMYT..................................... 12

2 Incrementos após 14 ciclos de seleção no híbrido intervarietal Jarvis Golden Prolific x Indian Chief.. ........................................................................... 12

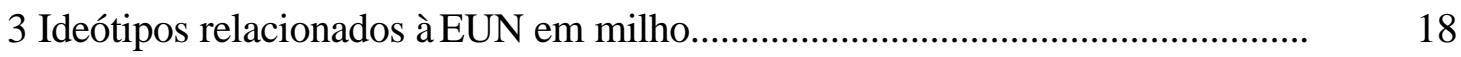

4 Parâmetros genéticos de variáveis relacionadas à EUN em milho. ..................... 19

5 Perfil isoenzimático de GR, CAT e SOD de raízes das linhas (2, 4 e 6) e seus híbridos $(24,26$ e 46) cultivados em alto e baixo suprimento de $\mathrm{N}$................... 51

6 Perfil isoenzimático de GR nas raízes das sub-amostras finas e grossas de plantas da linha 2 cultivadas com 1 e $10 \mathrm{mM}$ de $\mathrm{N}$, e também das raízes recém desenvolvidas das plantas do nível de 10 mM de N.......................................

7 Plantas de cevada cultivadas em cinco níveis de $\mathrm{N}(0,25,0,5,1,10$ e $20 \mathrm{mM})$, no dia da colheita do experimento

8 Perfil isoenzimático de GR, CAT e SOD de raízes de cevada cultivada em cinco níveis de $\mathrm{N}(0,25,0,5,1,10$ e $20 \mathrm{mM})$

9 Plantas de Arabidopsis thaliana cultivadas em cinco níveis de $\mathrm{N}(0,25,0,5,1$, 10 e $20 \mathrm{mM})$, no dia da colheita do experimento

10 Perfil isoenzimático de GR, CAT e SOD de raízes de Arabidopsis thaliana cultivada em cinco níveis de $\mathrm{N}(0,25,0,5,1,10$ e $20 \mathrm{mM})$ 


\section{LISTA DE TABELAS}

Página

1 Análise de variância: Probabilidades dos efeitos das doses de nitrogênio (N), genótipos $(\mathrm{G})$ e interação $(\mathrm{N}$ x $\mathrm{G})$ nas variáveis analisadas nos dois experimentos de campo.

2 Teste $\mathrm{F}$ para o efeito das doses de nitrogênio em cada linha $(2,3,4,5,6,10,13$ e 17) e controles BR 106 e Sintético Elite NT, e médias, sob alto e baixo N, de produtividade de grãos (g pl-1) e teor de clorofila (unidades SPAD), no experimento 1 .

3 Teste $\mathrm{F}$ para o efeito das doses de nitrogênio em cada linha $(2,3,4,5,6$ e 10$)$ e controles BR 106 e Sintético Elite NT, e médias, sob alto e baixo N, de produtividade de grãos, massa de cem grãos, prolificidade, sincronia do florescimento, teor de $\mathrm{N}$ nos grãos e $\mathrm{N}$ total no experimento 2.

4 Correlações simples entre a produtividade de grãos e as demais variáveis nas linhas e controles dos dois experimentos de campo

5 Análise de variância: Probabilidades para os efeitos da capacidade geral de combinação e da capacidade específica de combinação nos níveis alto e baixo de nitrogênio e na interação destes níveis, para as variáveis produtividade de grãos, massa de cem grãos, número de grãos, índice de colheita, número de folhas verdes, área da folha da espiga, eficiência na utilização do nitrogênio, nitrogênio total, teor de nitrogênio nos grãos, sincronia no florescimento, teor de clorofila e prolificidade .

6 Efeitos de capacidade geral de combinação nos níveis alto e baixo de nitrogênio, para as variáveis produtividade de grãos, número de grãos e teor de clorofila. 
7 Efeitos de capacidade geral de combinação na média dos níveis alto e baixo de nitrogênio, para as variáveis massa de cem grãos, índice de colheita, número de folhas verdes, área da folha da espiga, eficiência na utilização do nitrogênio, nitrogênio total, teor de nitrogênio nos grãos, sincronia no florescimento e prolificidade.

8 Efeitos de capacidade específica de combinação na média dos níveis alto e baixo de nitrogênio, para as variáveis produtividade de grãos, massa de cem grãos, número de grãos, índice de colheita, número de folhas verdes, área da folha da espiga, eficiência na utilização do nitrogênio, nitrogênio total, teor de nitrogênio nos grãos, teor de clorofila e prolificidade.

9 Correlações entre a produtividade de grãos e as demais variáveis nos 15 híbridos do Experimento 2.

10 Análise de variância: Probabilidades para os efeitos de nitrogênio $(\mathrm{N})$, genótipo (G), interação ( $\mathrm{N} \times \mathrm{G})$, heterose na média dos níveis de $\mathrm{N}$, heterose no nível baixo de $\mathrm{N}$ e heterose no nível alto de $\mathrm{N}$

11 Teste F para o efeito do nitrogênio em cada linha (2, 4 e 6) e híbrido (24, 26 e 46) de milho e médias das variáveis nos níve is alto e baixo de nitrogênio.

12 Valores das variáveis na média dos níveis alto e baixo de nitrogênio para as linhas $(2,4$, e 6$)$ e híbridos $(24,26$ e 46$)$ 


\section{LISTA DE SIGLAS, ABREVIATURAS E SÍMBOLOS}

$\mathrm{CAT}=$ catalase

CIMMYT $=$ Centro Internacional de Melhoramento de Milho e Trigo

$\mathrm{DTNB}=5,5$ 'ditiobis (2 - ácido nitrobenzóico)

DTT $=$ ditiotreitol

EDTA = ácido etileno diamino tetracético

$\mathrm{EC}=$ enzyme commission

EUN = eficiência no uso do nitrogênio

$\mathrm{GR}=$ glutationa redutase

$\mathrm{GSH}=$ glutationa reduzida

GSSG = glutationa oxidada

$\mathrm{N}=$ nitrogênio

$\mathrm{NADPH}=$ nicotinamida adenina dinucleotídeo fosfato reduzida

$\mathrm{NBT}=$ nitro blue tetrazolium

PVPP = polivinil polipirrolidona

$\mathrm{SOD}=$ superóxido dismutase

TEMED = N, N, N', N'- tetrametilenodiamina

TRIS $=$ Tris (hidroximetil) - Aminometano

$\mathrm{BCIP}=$ fosfato $5-$ bromo -4 cloro -3 indólico

PMS $=$ fenazina metassulfato

MTT $=$ metiltiazoletetrazolium

$\mathrm{DPIP}=2,6$ diclorofenol 


\title{
CRUZAMENTOS DIALÉLICOS ENTRE LINHAS DE MILHO CONTRASTANTES NO USO DO NITROGÊNIO
}

\author{
Autor: LEONARDO OLIVEIRA MEDICI \\ Orientador: Prof. Dr. RICARDO ANTUNES DE AZEVEDO
}

\section{RESUMO}

$\mathrm{O}$ melhor entendimento sobre como o milho responde ao suprimento de $\mathrm{N}$ é requerido por motivos econômicos e ambientais. Genótipos contrastantes são indispensáveis para estudos genéticos e fisiológicos e a identificação da resposta ao $\mathrm{N}$ de linhas de milho e seus híbridos foi o objetivo deste trabalho. Foram usadas sete linhas $\mathrm{S}_{5}$ e uma $\mathrm{S}_{4}$, originadas de dois híbridos comerciais. No primeiro experimento de campo, com duas doses de $\mathrm{N}$ e as linhas 2, 3, 4, 5, 6, 10 e 13, a dose alta de $\mathrm{N}$ apresentou efeito de excesso, aumentando a produtividade de grãos somente da linha 2, diminuindo a produtividade na linha 13 e aumentando o teor de clorofila em todas as linhas exceto na 3. No segundo experimento de campo, com as linhas 2, 3, 4, 5, 6, e 10, existiu severa deficiência de $\mathrm{N}$ reduzindo a produtividade de grãos nas linhas 2,3 , 5 e 10, a prolificidade nas linhas 2, 3, 4 e 5, o teor de $\mathrm{N}$ nos grãos em todas as linhas exceto a 10 , o $\mathrm{N}$ total nas linhas 2,3 , e 5 e a sincronia no florescimento nas linhas 3 e 5. Esta deficiência provocou o aumento na massa de cem grãos na linha 2. O comportamento interativo das linhas indica que estas variáveis possuem controle genético distinto em cada nível de $\mathrm{N}$. Estes resultados também indicam independência na resposta desta variáveis ao $\mathrm{N}$, pois não existiu consistência destas respostas entre as linhas. A análise dialélica, com os 15 híbridos provenientes das seis linhas do experimento anterior, indicou interação da capacidade geral de combinação (CGC) 
com os níveis de $\mathrm{N}$ para as variáveis produtividade de grãos, número de grãos por planta e teor de clorofila. Não houve associação entre as produtividades de grãos das linhas e dos seus efeitos de CGC para esta variável, nos níveis alto e baixo de $\mathrm{N}$. Existiu associação da sensibilidade da produtividade de grãos ao $\mathrm{N}$ das linhas com os seus efeitos de CGC para esta variável nos níveis alto e baixo de $\mathrm{N}$, uma vez que as linhas que sofreram os maiores efeitos das doses de $\mathrm{N}$ foram as de maior efeito de CGC, enquanto as linhas que sofreram os menores efeitos das doses de $\mathrm{N}$ apresentaram os menores efeitos de CGC. Esta associação indica que a resposta das linhas ao $\mathrm{N}$ deve ser considerada nos programas de melhoramento para EUN. As plantas do dialelo entre as linhas 2, 4 e 6, avaliadas em casa de vegetação com 32 dias após a germinação, apresentaram heterose média para absorção e utilização de $\mathrm{N}$, indicando a possibilidade de seleção precoce para estas variáveis, as quais também apresentaram significância para os efeitos não aditivos no experimento de campo. Foi detectada heterose média para a razão $F v / F m$ mas não para a fotossíntese indicando uma maior eficiência das medidas associadas à fluorescência da clorofila em relação àquelas associadas com a fixação de carbono. A deficiência de $\mathrm{N}$ reduziu o número de isoenzimas da glutationa redutase nas raízes de milho, cevada e Arabidopsis thaliana, e são discutidas possíveis explicações para este fenômeno, relacionadas à síntese de amido ou à proteção contra radicais livres. 


\title{
DIALLEL CROSSES AMONG MAIZE LINES CONTRASTING TO NITROGEN USE
}

\author{
Author: LEONARDO OLIVEIRA MEDICI \\ Adviser: Prof. RICARDO ANTUNES DE AZEVEDO
}

\section{SUMMARY}

A better understanding as to how maize responds to $\mathrm{N}$ supply is required for both economic and environmental purposes. Contrasting genotypes are indispensable for genetic and physiological studies of any trait. The investigation of the response to $\mathrm{N}$ supply for a range of maize lines, was the aim of this work. Seven $\mathrm{S}_{5}$ and one $\mathrm{S}_{4}$ lines, originating from two commercial hybrids, were studied for agronomic traits related to nitrogen use efficiency (NUE). Two field experiments with two levels of nitrogen were carried out. In the first experiment, in which the lines 2, 3, 4, 5, 6, 10, 13 and 17 were tested, the $\mathrm{N}$ supplied appeared to be in excess and only increased the grain yield in line 2, decreased the grain yield in line 13 and increased the chlorophyll content in all lines except line 3. In the second experiment, in which the lines 2, 3, 4, 5, 6 , and 10 were tested, there was a severe $\mathrm{N}$ deficiency that caused a reduction in grain yield in lines 2, 3, 5 and 10, prolificacy in lines 2, 3, 4 and 5, grain $\mathrm{N}$ content in all lines except line 10 and total plant $\mathrm{N}$ in lines 2, 3, and 5. On the other hand, a severe $\mathrm{N}$ deficiency caused an increase in hundred kernel weight in line 2 and anthesis-silking in lines 3 and 5. The interactive behaviour of these traits indicates that they have different genetic controls at each $\mathrm{N}$ level. These results also demonstrate that the response to $\mathrm{N}$ of these traits are under separate controls from each other, since they did not exhibit consistency in all the lines tested. The diallel analysis with 15 hybrids of the six lines 
from the previous experiment, indicated an interaction of the general combining ability (GCA) with the levels of $\mathrm{N}$ for the traits; grain yield, grain number per plant and chlorophyll content. There was no association between the grain yield of the lines and the effects of GCA for this variable, at either level of N. Productivity responses of grains to the $\mathrm{N}$ levels for the different lines was associated with GCA effects for this trait. The lines that suffered the largest dosage effects of $\mathrm{N}$ were the ones with the larger effect of GCA while the lines that suffered the smallest dosage effects of $\mathrm{N}$ presented the smallest effects of GCA. This association indicates that the response of the lines to $\mathrm{N}$ must to be considered in the genetics programs for improvement of NUE. The plants of the crosses between the lines 2, 4 and 6, evaluated in the glass house, 32 days after the germination, presented average heterosis for the absorption and utilization of $\mathrm{N}$. This indicates the possibility of precocious selection for these traits, which also presented significance non additive effects during the field experiment. Average heterosis was detected for $F v / F m$ but not for photosynthesis, which indicates a greater efficiency of the measurements associated to the chlorophyll fluorescence in relation to those associated with carbon fixation. The deficiency of $\mathrm{N}$ reduced the number of glutathione reductase isoforms in corn, barley and Arabidopsis thaliana roots, and possible explanations are discussed for this phenomenon, related to starch synthesis and the protection against free radicals. 


\section{INTRODUÇÃO}

A obtenção de maior eficiência no uso do nitrogênio (EUN) tem sido um objetivo buscado tanto para agricultura capitalizada, quanto para a de baixos insumos. Isto porque os desperdícios e a escassez deste elemento mineral, que é o mais exigido pelas plantas (Marschner, 1995), podem gerar problemas econômicos, ambientais, de saúde pública e de segurança alimentar.

Nitratos provenientes do escorrimento superficial e da lixiviação representam perda de capital investido e ainda contaminam a água, podendo gerar eutroficação (Mehner \& Beedorf, 1995), metahemoglobinemia e câncer (Mc Knight et al, 1999). Emissões de amônia e óxidos de nitrogênio representam outra perda econômica, com o agravante destes óxidos gerarem efeito estufa, degradação da camada de ozônio na troposfera e chuvas ácidas (Matson et al, 1998). Baixos insumos são uma realidade em 60\% da agricultura mundial (Ceccarelli, 1996), e nestas condições a seca e a deficiência de nitrogênio $(\mathrm{N})$ estão entre os maiores responsáveis pelas baixas produtividades dos cereais (Lea \& Morot-Gaudry, 2001).

Existem diversas soluções possíveis para aumentar a EUN. Uma das mais simples, é a diminuição nas doses de adubos, para níveis que sejam produtivos e seguros (Fernández et al, 1998). Leguminosas em rotações (Kumar \& Goh, 2000) ou no cultivo em aléias (Zaharah et al, 1999) fornecem $\mathrm{N}$ e ainda melhoram várias características do solo. A fixação biológica de $\mathrm{N}$ poderá ser aumentada em gramíneas. Esta fixação é feita por endófitos que colonizam o apoplasto (James \& Olivares, 1998) ou para-nódulos induzidos artificialmente (Christiansen-Weninger, 1998). A agricultura de precisão pode otimizar a fertilização (Raun \& Johnson, 1999). Outra possibilidade é o melhoramento genético, que já está gerando milhos produtivos em solos pobres em N (Santos, 1998; Machado, 1997; Lafitte \& Edmeades, 1994b). 
A seleção de genótipos com maior EUN é baseada principalmente na produtividade, mas variáveis secundárias, com elevadas herdabilidade e correlação com produtividade, podem acelerar o progresso genético (Bänziger \& Lafitte, 1997). Diversas foram estudadas ou mesmo utilizadas tais como: teor de clorofila da folha da espiga, altura da planta e velocidade de senescência (Lafitte \& Edmeades, 1994a), sincronia no florescimento (Santos et al, 1998), eficiência na absorção, na utilização e na translocação, (Moll et al, 1982), e cinéticas de absorção e atividades de enzimas da assimilação do N (Reggiani et al, 1999; Majerowicz et al, 2002). Loci de caracteres quantitativos relacionados à EUN também têem sido sugeridos para uso em seleção assistida (Agrama et al, 1999).

A validação das variáveis secundárias para a EUN em milho ainda está em curso. Foram encontradas correlações entre a atividade da nitrato redutase (NR, EC: 1.6.6.1) e a produção de grãos (Murulli \& Paulsen, 1981), e foi também observado que materiais com alta atividade da NR tendem a ser responsivos à adubação nitrogenada $\mathrm{e}$ eficientes no uso do $\mathrm{N}$ em ambientes pobres em N (Purcino et al, 1990). Por outro lado Eichelberger et al. (1989) verificaram que a seleção divergente para a atividade da NR foi eficiente, mas estas alterações não elevaram a produtividade. $O$ valor adaptativo do nível de atividade desta enzima parece ser espécie específico, uma vez que se observa ganhos em crescimento com a super-expressão em Arabidopsis mas não em diversas plantas tais como Nicotiana plumblaginifolia (Singh \& Jaiwal, 1999). A seleç

ão para altura da planta, sob $\mathrm{N}$ baixo colaborou para o aumento da biomassa sob baixo N, mas não para a produtividade (Lafitte \& Edmeades, 1994a). A prolificidade foi associada com a produtividade apenas em $\mathrm{N}$ alto por Moll et al. (1987), entretanto, correlação significativa foi encontrada para produtividade em baixo $\mathrm{N}$ (Kling et al, 1997).

A EUN é um caráter complexo, dependente de vários processos fisiológicos tais como absorção, assimilação e retranslocação do nitrogênio pela planta, e o seu melhor entendimento poderá colaborar para mitigar os problemas associados à falta e ao excesso de nitrogênio na agricultura. 
O objetivo deste trabalho foi o de avaliar características genéticas de variáveis agronômicas, fisiológicas e bioquímicas, relacionadas ao uso eficiente do nitrogênio em linhas de milho cruzadas em esquema dialélico.

Inicialmente foram realizados dois ensaios de campo na Estação Experimental Anhembi da ESALQ-USP, na tentativa de identificar materiais contrastantes para a resposta de variáveis agronômicas à aplicação de nitrogênio. Linhas contrastantes foram identificadas e cruzadas em esquemas dialélicos que foram avaliados em um ensaio de campo e um ensaio de casa de vegetação com dois níveis de disponibilidade de nitrogênio, nos quais foram avaliadas variáveis relacionadas ao uso eficiente do nitrogênio. Em função da observação do efeito da disponibilidade de nitrogênio na atividade de enzimas antioxidantes, este efeito foi estudado também em um experimento, de casa de vegetação com cevada, e em outro, em sala de crescimento com Arabidopsis. 


\section{REVISÃO DE LITERATURA}

\subsection{Conceitos sobre eficiência no uso do nitrogênio}

A eficiência no uso de um elemento nutricional pode ser entendida como uma tolerância à limitação da disponibilidade deste nutriente.

Em Fisiologia Vegetal existem basicamente duas definições relacionadas à eficiência no uso do nitrogênio: a eficiência no uso do $\mathrm{N}$ definida como a razão mg de matéria seca da planta/mg de $\mathrm{N}$ na planta, e a eficiência no uso do $\mathrm{N}$ para a fotossíntese definida como a razão $\mathrm{mg}$ de $\mathrm{CO}_{2}$ fixado/mg de $\mathrm{N}$ na planta (Larcher, 1995).

Especificamente em milho, Moll et al (1982) definiram a "eficiência no uso do N" como a massa de grãos dividida pela massa de $\mathrm{N}$ aplicado no solo (Gw/Ns), ambas expressas na mesma unidade, como por exemplo g/planta. Definiram também dois componentes primários desta eficiência, que são chamados de eficiência na absorção e eficiência na utilização. $\mathrm{O}$ primeiro é a quantidade de $\mathrm{N}$ total na planta na maturidade dividido pelo $\mathrm{N}$ aplicado no solo ( $\mathrm{Nt} / \mathrm{Ns}$ ), e o segundo é a massa de grãos dividida pelo $\mathrm{N}$ total da planta na maturidade $(\mathrm{Gw} / \mathrm{Nt})$. A eficiência no uso seria o produto da eficiência na absorção pela eficiência na utilização. Outros termos são definidos como possibilidades de expansão da expressão primária, tais como a absorção de $\mathrm{N}$ até o florescimento $(\mathrm{Nv})$, absorção de $\mathrm{N}$ durante o enchimento $(\mathrm{Na}), \mathrm{N}$ acumulado no grão $(\mathrm{Ng})$, além de expressões associando estes termos, como por exemplo os grãos produzidos por unidade de $\mathrm{N}$ no grão $(\mathrm{Gw} / \mathrm{Ng})$ ou a fração do $\mathrm{N}$ total que é translocado para o grão $(\mathrm{Ng} / \mathrm{Nt})$ e etc. Neste trabalho os autores comparam vários materiais genéticos de milho e mostram que os componentes da EUN podem ser diferentes mesmo entre híbridos com similar EUN total. 
Liang \& MacKenzie, (1994) definiram a EUN com a recuperação de ${ }^{15} \mathrm{~N}$ na planta e no grão, ou seja, a porcentagem do ${ }^{15} \mathrm{~N}$ aplicado ao solo que absorvida pela planta.

Rosielle \& Hamblin (1981) usam uma definição de material genético tolerante à um estresse como sendo aquele que apresenta a menor diferença de resposta produtiva entre os ambientes com e sem estresse. Os índices de Moll et al. (1982), como por exemplo a eficiência total ( $\mathrm{g}$ de grãos/g $\mathrm{N}$ aplicado), não levam em consideração esta diferença de resposta, e, desta forma, basta que um material seja mais produtivo que outro na média de ambas as condições para ser indicado como mais eficiente, pois se já produziu mais, o fato de dividir esta produção pela mesma quantidade de $\mathrm{N}$, aplicado em todos os materiais, não irá alterar a aparente superioridade. E esta superioridade pode não ser relacionada ao melhor uso do $\mathrm{N}$, como estaria sugerindo este índice, mas pode estar relacionada a outra qualidade. Geralmente estes índices de Moll et al. (1982) são aplicados ao comportamento médio nos diferentes níveis de $\mathrm{N}$, ou em ambos os níveis separadamente. O comportamento durante a mudança de níveis de $\mathrm{N}$ indica a diferença entre materiais especificamente quanto ao uso do $\mathrm{N}$ pois quando materiais interagem com o $\mathrm{N}$ é sinal de que genes diferentes estão sendo usados por cada um deles nos ambientes com níveis diferentes de N. Esta lógica tem sido adotada como por exemplo em Santos et al. (1988) que definiram o material tolerante como o que teve menor perda de produção quando da passagem de um ambiente fértil para um pobre em N. Fischer et al (1983) descreveram um índice de seleção que também considera a queda na produção devida à deficiência de N. Este índice, chamado "Low N index", é utilizado para seleção simultânea em ambientes com e sem estresse, evitando assim a obtenção de materiais adaptados para condições específicas. A fórmula usada é:

Low $N$ index $=\mathrm{Y}_{\mathrm{a}}(-\mathrm{N}) / \mathrm{Y}_{\mathrm{a}}(+\mathrm{N}) \times \mathrm{Y}_{\mathrm{x}}(-\mathrm{N}) / \mathrm{Y}_{\mathrm{x}}(+\mathrm{N})$

Onde:

$\mathrm{Y}_{\mathrm{a}}(-\mathrm{N})$ é a produção do genótipo "a" sob baixo $\mathrm{N}$;

$\mathrm{Y}_{\mathrm{a}}(+\mathrm{N})$ é a produção do genótipo "a" sob alto $\mathrm{N}$;

$\mathrm{Y}_{\mathrm{x}}(-\mathrm{N})$ é a produção média de todos os genótipos sob baixo $\mathrm{N}$ e 
$\mathrm{Y}_{\mathrm{x}}(-\mathrm{N})$ é a produção média de todos os genótipos sob alto $\mathrm{N}$.

Um valor alto deste índice indica relativa tolerância à deficiência de $\mathrm{N}$, e valor reduzido indica relativa sensibilidade.

Siddiqi \& Glass (1981) sugeriram uma abordagem diferente para o conceito de eficiência ao qual chamaram de "índice de eficiência". Este índice é calculado com a divisão da biomassa pela concentração do nutriente na biomassa. Segundo os autores este novo conceito é mais adequado do que quando se divide a biomassa pela quantidade absoluta de nutriente na biomassa, por dois motivos: a produção de biomassa recebe um peso maior pois a fórmula acaba ficando como biomassa elevada ao quadrado, dividida pela quantidade de nutriente ( $\mathrm{g}$ biomassa ${ }^{2} / \mathrm{g}$ nutriente) e ainda os processos fisiológicos devem se basear na concentração de nutriente ao invés da quantidade absoluta. Desta forma uma planta que produza pouco e acumule nutriente menos ainda, vai ser considerada eficiente nos termos de eficiência tradicional (g biomassa/g nutriente) e uma que tenha muita biomassa mas muito nutriente também seria considerada ineficiente. Com a abordagem de índice de eficiência, a primeira planta seria considerada inferior àquela que cresceu mais.

Fox (1978) sugeriu uma abordagem para classificar genótipos, quanto a resposta ao nutriente, que considera a produtividade e a diferença de produtividade entre os ambientes com disponibilidades diferentes do nutriente. Os genótipos são posicionados em gráfico no qual o eixo "x" é a produção na dose alta e o eixo "y" é a produção na dose baixa. Neste gráfico, quatro quadrantes são definidos, por retas perpendiculares aos eixos, posicionadas nas médias de produção de cada eixo. Os materiais genéticos são classificados em função do quadrante que ocupam. "Eficiente responsivo" produz acima da média nos dois níveis do nutriente. "Ineficiente responsivo" produz abaixo da média no nível baixo, mas responde ao acréscimo de nutriente, posicionando-se acima da média no nível alto. "Eficiente não responsivo" fica acima da média no nível baixo, mas não responde ao acréscimo ficando abaixo da média no nível alto. "Ineficiente não responsivo" está abaixo da média em ambos os níveis. 
Outro conceito é o "índice de nutrição de nitrogênio" que é a razão entre a concentração medida na planta e a concentração "crítica", a qual é a concentração em plantas em condições não limitantes. $O$ índice de nutrição de nitrogênio maior que 1 indica consumo de luxo, enquanto os valores menores do que 1, indicam deficiência (Belanger \& Gastal, 2000).

Greenwood et al. (1986) usaram uma representação quantitativa da redução no crescimento causada pelo estresse de deficiência de N. Esta representação foi chamada "nitrogen stress $\left(\mathrm{S}_{\mathrm{N}}\right)$ ". Por exemplo, se a taxa de crescimento de um cereal, sob deficiência de $\mathrm{N}$, é de $7 \mathrm{~g}$ de biomassa $\mathrm{m}^{-2} \mathrm{dia}^{-1}$ e a taxa de crescimento sem esta limitação nutricional é de $10 \mathrm{~g}$ de biomassa $\mathrm{m}^{-2} \mathrm{dia}^{-1}$, então o $\mathrm{S}_{\mathrm{N}}$ seria de $30 \%$.

Clark \& Duncan (1991) ressaltam que os conceitos e aproximações de eficiência em relação ao $\mathrm{N}$ são variados e em muitos casos confusos. Isto pode ser devido ao vasto número de definições de eficiência ao $\mathrm{N}$ e a falta de consenso sobre quais variáveis são importantes para o produto final, geralmente produção de grãos. A genética dos fatores relacionados à eficiência no uso do $\mathrm{N}$ precisam ser esclarecidas para manipular ou selecionar germoplasma para condições específicas de disponibilidade de $\mathrm{N}$.

\subsection{Seleção em ambientes com e sem deficiência de nitrogênio}

Uma primeira impressão que se pode ter, é que o melhor local de seleção é o próprio local de destino da cultura. Esta impressão encontra confirmação no trabalho de Murruli \& Paulsem (1981), que selecionaram milho em solos com alta e baixa dose de $\mathrm{N}$ e mostraram a superioridade da seleção específica, uma vez que o material selecionado na dose baixa foi o mais produtivo no cultivo em solo pobre, enquanto ocorreu o contrário no cultivo em solo bem adubado, ou seja, o material selecionado na dose alta é que foi superior. O trabalho de Agrama (1999) também confirma a existência desta especificidade, ao encontrar regiões cromossômicas diferentes associadas às produtividades em solos com e sem estresse de $\mathrm{N}$. 
Uma outra resposta é encontrada em Moll et al. (1982), que mostraram que a seleção em solo deficiente gerou milhos melhores somente para solos férteis. Isto porque a deficiência permitiu descriminar os mais prolíficos.

Por outro lado ainda, existem trabalhos mostrando que é possível aumentar a produtividade em solos pobres em $\mathrm{N}$ sem prejudicar a produtividade em solos férteis. A população Across 8339 BN vem demonstrando isto após seleção para produtividade tanto no ambiente com deficiência de $\mathrm{N}$ quanto no solo sem esta limitação (Lafitte \& Edmeades, 1994a). Este trabalho se aproxima da definição de Rosielle \& Hamblin (1981) para a definição da situação teórica mais favorável para melhorista, que é quando a tolerância e a produtividade são positivamente correlacionadas, e isto deve ocorrer quando a variância genética é alta no ambiente estressado, e também é alta e positiva a correlação genética entre os ambientes estressado e não estressado. Outros trabalhos também indicam a possibilidade de associação entre tolerância e produtividade. Um exemplo é o dos híbridos modernos dos EUA, que superam os antigos tanto em $\mathrm{N}$ baixo quanto em $\mathrm{N}$ alto (Duvick, 1984). Outro exemplo são as variedades locais brasileiras, que estiveram muito tempo submetidas à solos pobres, e são menos produtivas, mesmo em solo pobre, do que os materiais melhorados para solos férteis (Machado et al., 1998). Lafitte et al. (1997) também mostraram que variedades locais tropicais foram menos produtivas, em solos pobres em $\mathrm{N}$, do que materiais melhorados. Fontes para tolerância à solos pobres em $\mathrm{N}$ não têem sido especificamente localizadas e, ao que parece, materiais de alta produtividade podem ser melhorados para este fim. A população que deu origem ao Across, por exemplo, vinha sendo selecionada em solos com alto nível de N (Lafitte \& Edmeades, 1994a). A população Sintético Elite NT, que vem sendo melhorada com êxito para produtividade em solos pobres em N, também passou por seleção em solo fértil antes de sofrer seleção sob deficiência de N (Santos et al., 1998). Outro exemplo ainda é o das variedades Sol da Manhã Nitroflint e BR 106, melhoradas respectivamente em solo com e sem deficiência de $\mathrm{N}$ e que apresentam produtividades semelhantes, mesmo em solos pobres (Machado et al., 1998). Considerando estas evidências, pode-se inferir 
que a tolerância à deficiência de $\mathrm{N}$ e a produtividade podem ser convergentes em milho, mesmo que existam genes específicos para cada uma destas características.

\subsection{Fisiologia e genética da eficiência no uso do nitrogênio}

Os trabalhos que serão abaixo expostos trazem de forma isolada ou combinada duas preocupações: entender a EUN e utilizar os seus indicadores no melhoramento.

Dois híbridos canadenses são usados como um modelo para estudos de EUN, o Pride 5, lançado em 1959, e o Pioneer 3902, lançado em 1989. Dwyer et al. (1995) observaram que Pride 5 reduziu a fotossíntese antes que Pioneer 3902 que ficou verde mais tempo durante o enchimento. Ma \& Dwyer (1998) comparando este par de híbridos encontrou que Pioneer 3902 absorveu 20\% mais N, produziu 24\% mais matéria seca durante o enchimento e teve $24 \%$ mais matéria seca total e produção de grãos, mas teve menor teor de $\mathrm{N}$ no grão que o Pride 5, este que retranslocou mais $\mathrm{N}$, sugerindo que este componente da eficiência, ou seja a eficiência na translocação, não seria importante para a EUN. A retranslocação é importante, entretanto, para cereais de grãos pequenos. Os dados sugerem que manutenção de folhas verdes por mais tempo para a fotossíntese durante o enchimento e a habilidade de absorver $\mathrm{N}$ durante $\mathrm{o}$ enchimento seriam características de milhos híbridos com maior EUN. É interessante ressaltar que neste trabalho não houve interação híbridos x N para produção de grãos, e isto pode indicar que embora o milho recente seja mais produtivo e tenha alguns componentes da EUN superiores ao antigo, as EUN de ambos consideradas em conjunto devem ser semelhantes, pois quando se adicionou $\mathrm{N}$ as suas produtividades aumentaram em proporções semelhantes.

McCullough et al (1994b), trabalhando com este par de híbridos na fase de crescimento vegetativo, observaram que o Pride apresentou taxa de emergência de folhas menor que do P3902 sob baixo N, e o P3902 teve fotossíntese de 4 a 27\% maior, com as maiores diferenças ocorrendo em baixo $\mathrm{N}$ e foi coletivamente mais tolerante à deficiência de $\mathrm{N}$ durante o crescimento vegetativo. Segundo McCullough et al. (1994a), a taxa de absorção de N por unidade de área foliar no Pioneer 3902 foi maior no máximo estresse de $\mathrm{N}$ experimentado, mas com alto $\mathrm{N}$ o Pride teve taxa 
maior. Absorção de N por unidade de massa de raiz foi maior no Pioneer 3902 sob médio e baixo estresse. P3902 manteve maior fotossíntese por unidade de $\mathrm{N}$ foliar independente do suprimento de $\mathrm{N}$. $\mathrm{O}$ Pride sob $\mathrm{N}$ baixo teve maior partição de $\mathrm{N}$ e matéria seca para as folhas. A alta EUN do P3902 sob baixo N é associada com maior absorção de $\mathrm{N}$ e alto teor de $\mathrm{N}$ por unidade de folha indicando que o novo material investe prioritariamente em fotossíntese ao invés de produção de área foliar.

Uhart \& Andrade (1995) demonstraram que em milho, limitando-se artificialmente a fonte (através do sombreamento após a floração para reduzir a fotossíntese durante o enchimento), a remobilização de $\mathrm{N}$ reduzido da folha e do caule aumentou e também a de carboidratos não estruturais do caule. Por outro lado, limitando-se o dreno (através de sombreamento antes da floração, para reduzir o número de flores femininas), houve acúmulo maior de carboidrato não estrutural no caule e menos $\mathrm{N}$ reduzido foi remobilizado das folhas e do caule. Ou seja, a redução na fonte gera maior remobilização, enquanto que redução no dreno gera menor remobilização. As plantas com a capacidade de dreno limitada tiveram grande absorção de $\mathrm{N}$ após a antese e maior $\mathrm{N}$ no grão do que as plantas com a fonte limitada. Quando a razão fonte/dreno diminuiu, o fluxo de $\mathrm{N}$ em relação ao de carbono para o grão diminuiu, sugerindo que o $\mathrm{N}$ se torna mais limitante para a produção de grãos quando a fonte fica limitada. Ou seja, com redução na capacidade de fonte, vai faltar mais $\mathrm{N}$ do que $\mathrm{C}$ para o grão.

A prolificidade, ou número de espigas por planta, é uma variável freqüentemente considerada nos trabalhos sobre EUN. Moll et al. (1987) executaram seleção para prolificidade e EUN como definida por Moll et al. (1982), e esta conduziu a aumento da eficiência e da produtividade, (pois aumentou a responsividade ao $\mathrm{N}$ aplicado) em ambientes com alto nível de $\mathrm{N}$, mas não em $\mathrm{N}$ baixo. A seleção para prolificidade em ambientes pobres em $\mathrm{N}$ e para produtividade em solos ricos foi tão efetiva quanto a seleção para uso eficiente do $\mathrm{N}$ médio entre os ambientes. As seleções somente para produtividade em um ambiente ou para a média nos ambientes foram menos efetivas que as seleções para prolificidade em solo pobre ou eficiência média no uso do $\mathrm{N}$. Teor de $\mathrm{N}$ não foi importante para identificar materiais mais produtivos. 
Eficiência na absorção e na utilização contribuíram igualmente na predição da produtividade dos híbridos.

Bänziger \& Lafitte (1997) analisaram 90 ensaios do CIMMYT (Centro Internacional de Melhoramento de Milho e Trigo) sem aplicação de $\mathrm{N}$, quanto às correlações entre caracteres secundários e a produtividade, as herdabilidades no sentido amplo destes caracteres, e foi previsto o progresso genético para cada um e para as combinações deles. As características foram produtividade, sincronia no florescimento (intervalo entre o florescimento masculino e feminino), prolificidade, concentração de clorofila foliar, e a senescência, medida como o número de folhas verdes, abaixo da espiga, 2 e 5 semanas após o florescimento. Na Figura 1 consta um resumo destes resultados. A seleção direta para produtividade foi superior às seleções por simples características secundárias em muitos experimentos. Quando todas as características foram combinadas no índice Smith-Hazel, o qual confere pesos aos caracteres de acordo com as covariâncias genotípicas e fenotípicas deles com a produtividade, a seleção, foi 14\% superior à seleção para produtividade apenas. Dentre os parâmetros, o número de espigas por planta e senescência foliar discriminaram os materiais mais produtivos. Sincronia no florescimento e teor de clorofila conferiram informação sobre a variação ambiental dentro dos experimentos. Foi concluído que no melhoramento para solos pobres em $\mathrm{N}$, onde a herdabilidade para a produtividade é baixa, é recomendável usar parâmetros secundários na seleção. 


\begin{tabular}{|l|l|l|}
\hline Parâmetro & Herdabilidade & Correlação Genética \\
\hline Produtividade & 0,46 & - \\
\hline IFMF & 0,52 & $-0,47$ \\
\hline Clorofila & 0,35 & 0,24 \\
\hline Senescência & 0,60 & 0,42 \\
\hline Prolificidade & 0,44 & 0,78 \\
\hline
\end{tabular}

Figura 1 - Herdabilidades e correlações genéticas de variáveis secundárias com a produtividade em 90 ensaios de milho do CIMMYT. Fonte Bänziger \& Lafitte (1997).

Moll et al. (1994) realizaram o cruzamento entre as variedades Jarvis Golden Prolific e Indian Chief com posterior seleção recorrente recíproca e de famílias de irmãos completos. Os incrementos após 14 ciclos de seleção no híbrido intervarietal estão na Figura 2.

\begin{tabular}{|l|l|l|}
\hline Característica & $\begin{array}{l}\text { Seleção recorrente de } \\
\text { irmãos completos }\end{array}$ & $\begin{array}{l}\text { Seleção recorrente } \\
\text { recíproca }\end{array}$ \\
\hline Massa de grãos & $23 \%$ & $27 \%$ \\
\hline Acúmulo de matéria seca & $12 \%$ & $21 \%$ \\
\hline Absorção de N & $4 \%$ & $10 \%$ \\
\hline
\end{tabular}

Figura 2 - Incrementos após 14 ciclos de seleção no híbrido intervarietal Jarvis Golden Prolific x Indian Chief. Fonte Moll et al. (1994).

Após a seleção de irmãos completos a partição de $\mathrm{N}$ e $\mathrm{C}$ para os grãos foi elevada, entretanto a produção de fotoassimilados não foi suficiente para suprir as demandas dos grãos, parte aérea e raiz. Já a seleção recorrente recíproca resultou em grande aumento na produção de fotoassilmilados que foram suficientes para elevar a produção dos grãos e para manter a absorção de $\mathrm{N}$ pelas raízes. Heterose foi identificada para absorção de $\mathrm{N}$, peso de grãos e matéria seca total. Os autores indicam 
a hipótese de que a seleção para aumento na produção resultante de eficiente aquisição de $\mathrm{N}$ somente é suportada por incremento na produção de fotoassimilados.

No CIMMYT, vem sendo desenvolvido um programa seleção recorrente de irmãos completos, para alta produção em baixo $\mathrm{N}$, com manutenção do potencial produtivo em solos férteis. Esta população que vem sendo melhorada é denominada Across $8328 \mathrm{NB}$, e foi originada da população de milho tropical de terras baixas, denominada 28 Amarillo Dentado. As famílias superiores foram identificadas com um índice de características incluindo alta produtividade sob alto $\left(200 \mathrm{~kg} \mathrm{~N} \mathrm{ha}^{-1}\right)$ e baixo $\mathrm{N}$ (nenhuma aplicação) e alta concentração de clorofila na folha da espiga, senescência lenta e altura, medidos em solo com deficiência de N. Uma tentativa foi feita para manter altura de planta e tempo para florescer sob $\mathrm{N}$ alto inalterado. Lafitte \& Edmeades (1994b) analisaram as mudanças resultantes desse programa. Os ciclos 0, 1, 2 e 3 foram avaliados em dois níveis de $\mathrm{N}\left(0\right.$ e $\left.200 \mathrm{~kg} \mathrm{~N} \mathrm{ha}^{-1}\right)$ em 4 estações. $\mathrm{O}$ aumento linear por ciclo em produção sob baixo $\mathrm{N}$ foi de $2,8 \%\left(75 \mathrm{~kg} \mathrm{ha}^{-1}\right)$, e sob alto $\mathrm{N}$ foi de 2,3\% (137 $\left.\mathrm{kg} \mathrm{ha}^{-1}\right)$, indicando que a melhora na performance sob baixo $\mathrm{N}$ é compatível com a performance sob alto N. O aumento na produção, na média dos dois níveis de $\mathrm{N}$, foi associado com número de grãos por espiga (1,6\%), altura da planta $(4,4 \%)$, dias para a antese $(0,4 \%)$, biomassa de toda parte aérea no florescimento $(3,5 \%)$ e na maturidade $(1,9 \%)$, e perda de $\mathrm{N}$ das partes vegetativas para os grãos durante o enchimento $(4,8 \%)$. Na média dos níveis de $\mathrm{N}$ existiu um decréscimo no número de flores formadas por espiga $(-1,5 \%)$, mas aumento no número de flores que formarão grãos $(3,1 \%)$. A taxa de senescência foliar diminuiu com a seleção. Os ciclos de seleção diferiram significativamente no $\mathrm{N}$ total absorvido e acúmulo de biomassa no tempo, mas nenhuma tendência consistente foi observada para essas características. A seleção para performance sob baixo $\mathrm{N}$ em germoplasma elite de milho parece melhorar a eficiência com que o $\mathrm{N}$ é utilizado para produzir biomassa e grãos. A sincronia no florescimento foi elevada pela seleção. A seleção para performance sob baixo N, usando a aproximação ideotípica da combinação de características morfológicas secundárias, resultou em melhoramento para ambos os níveis de $\mathrm{N}$. Seleção foi acompanhada para aumento na biomassa, mas sem o correspondente 
aumento na absorção de N. É possível que exista maior variação genética, nesta população, para a eficiência na utilização do que eficiência na absorção. A seleção afetou o acúmulo de biomassa e a remobilização de N. As trocas observadas com a seleção nesta população conferiram vantagens tanto nos ambientes normais quanto limitados por $\mathrm{N}$, contudo o critério usado pode não ser o melhor ou a única aproximação para chegar àquele fim, e os resultados poderiam ter sido bastante diferentes se a seleção fosse somente para produção sob baixo N. Os critérios utilizados enfatizaram o aumento de biomassa (altura e área foliar sob baixo $\mathrm{N}$ e atraso na senescência). Os autores acreditam que o aumento na partição desta biomassa para a produção de grãos deve ter sido somente parcialmente completada.

Lafitte \& Edmeades (1994c) buscaram identificar possíveis causas do aumento na variação da produtividade com a seleção para tolerância à baixo teor de $\mathrm{N}$ em quatro ciclos de seleção. Across $8328 \mathrm{BN}$ foi plantado em 12 ambientes irrigados com variação em $\mathrm{N}$ e radiação. Algumas características foram específicas para cada ambiente, por exemplo, em solo fértil existiu uma positiva correlação entre acumulação de $\mathrm{N}$ antes do florescimento, mas em solo pobre em $\mathrm{N}$ esta associação não existiu. Existiu também variação nas correlações influenciada pelas estações. $\mathrm{O}$ teor de $\mathrm{N}$ na flor e no grão maduro, sob $\mathrm{N}$ baixo, mostraram positiva correlação $(0,97, \mathrm{P}<$ 0,03) em uma estação, enquanto que na subsequente, foi de - 0,98 . $\mathrm{O}$ ciclo $\mathrm{C}_{1}$ mostrou grande variação entre os ambientes e esta variação parece estar relacionada com um super investimento em biomassa vegetativa antes do florescimento, sem concomitante aumento no tamanho do dreno após o florescimento. Em $\mathrm{C}_{3}$ o número de grãos por planta aumentou, mas a produtividade aparentemente foi limitada pela capacidade da fonte nos últimos estádios do enchimento dos grãos. $\mathrm{C}_{3}$ também produziu $25 \%$ mais raízes, que o $\mathrm{C}_{0}$, em solo rico em $\mathrm{N}$, enquanto que a biomassa da parte aérea aumentou apenas 9\%. Mudanças na partição de biomassa para a raiz parecem ser importantes para a adaptação à baixo $\mathrm{N}$. Os resultados indicam que a diferença sazonal e a magnitude do suprimento de $\mathrm{N}$ são importantes para a determinação do valor adaptativo das características avaliadas. Seleção para tolerância à baixos teores de N, aparentemente, perturba mais a relação fonte - dreno do que a seleção para solos sem 
limitação de $\mathrm{N}$. A seleção enfatizando o acúmulo de $\mathrm{N}$ antes do florescimento pode ser ineficiente para solos onde o $\mathrm{N}$ é menos perdido por lixiviação ou volatilização e assim pode ser assimilado durante o enchimento. No processo de seleção com ruas simples para cada família de irmãos completos, este potencial pode não ter sido observado pois as famílias precocemente vigorosas acabaram retirando o $\mathrm{N}$ das demais. Este efeito pode ter contribuído para o grande aumento na biomassa da raiz com apenas 3 ciclos de seleção. Embora os autores tenham alertado para a competição por $\mathrm{N}$ entre as famílias durante a seleção, Bänziger et al. (1995) fizeram um experimento com vários tamanhos de bordadura e concluíram que embora a competição entre progênies adjacentes sem bordaduras tenha sido significante, o efeito foi pequeno para alterar a classificação dos materiais. Menos de $10 \%$ das diferenças entre as progênies foram devidas à competição. A comparação das variações residuais entre parcelas com diferentes tamanhos indica que a variação espacial da fertilidade do solo contribui mais que a competição para os erros do acaso. A competição pode ser mais importante quando se trabalha com linhas muito vigorosas ou muito adensadas. Experimentos com parcelas grandes aumentam o gasto de semente e isso pode não aumentar a precisão experimental pois a variação de fertilidade do solo e textura pode ser encontrada com uma expansão da área experimental.

Lafitte \& Edmeades (1994a) avaliaram a significância adaptativa e a herdabilidade de variáveis secundárias, que sejam de fácil mensuração para uso em programas de melhoramento, para solos pobres em $\mathrm{N}$, através de seleção divergente. Foram formadas, a partir do ciclo 0 de Across 8328, 14 cultivares experimentais das melhores e piores famílias para cada variável ou conjunto de varáveis: produção em alto $\mathrm{N}$, produção em baixo $\mathrm{N}$, produção média entre os níveis de $\mathrm{N}$, concentração de clorofila da folha da espiga em baixo $\mathrm{N}$, área da folha da espiga em baixo $\mathrm{N}$, taxa de senescência em baixo $\mathrm{N}$, e combinação das variáveis. Após 2 ciclos de seleção sob solos pobres em $\mathrm{N}$, usando o índice baseado neste conjunto de variáveis, foram formadas novamente 14 variedades experimentais como no ciclo 0 e mais 2 variedades baseadas na altura sob baixo N. As herdabilidades foram maiores no baixo N. Plantas mais produtivas sob baixo $\mathrm{N}$ foram as mais altas, com maior índice de área foliar $\mathrm{e}$ 
com maior partição de $\mathrm{C}$ e $\mathrm{N}$ para as espigas como denotado pela elevada sincronia no florescimento, ou seja, o reduzido intervalo entre os florescimentos masculino e feminino. A seleção divergente confirmou estas associações e revelou que o aumento na partição aumentou o número de grãos por espiga, o índice de colheita, o índice de colheita de $\mathrm{N}$ (g de $\mathrm{N}$ nos grãos/g de $\mathrm{N}$ na parte aérea) e a eficiência de utilização do $\mathrm{N}$ para produção de grãos (g de grãos/g de $\mathrm{N}$ na parte aérea). A seleção para produtividade sob baixo $\mathrm{N}$ somente, foi tão eficiente quanto a seleção usando variáveis do ideótipo para alta produtividade sob baixo N. O progresso no melhoramento só foi obtido quando a produtividade foi incluída nos parâmetros de seleção. A vantagem dos parâmetros secundários foi menos evidente do que no caso do melhoramento para seca, no qual a inclusão do IFMF melhorou significativamente o progresso em relação à seleção só para produtividade sob seca. A seleção pelo ideótipo foi, porém, a única que levou ao aumento na produção de biomassa sob baixo $\mathrm{N}$ sem concomitante atraso no florescimento. Ênfase na maior altura e área foliar sob baixo $\mathrm{N}$ e atraso na senescência (neste trabalho não houve diferença entre as taxas de senescência dos materiais selecionados divergentemente e foi presumido que a maior demanda devido à maior quantidade de drenos pode justificar esta semelhança) podem indicar melhora na captura de $\mathrm{N}$ e carbono mas não indicam muito sobre o uso deste para formar os drenos, enquanto que a sincronia no florescimento pode ser um indicador desta capacidade. Os autores indicaram seleção sob baixo $\mathrm{N}$, pois nesta condição a herdabilidade dos parâmetros desejáveis foi maior, mesmo considerando a maior variabilidade ambiental desta condição. Solos pobres em N e uniformes, portanto, são um grande recurso em estudos deste tipo. As seleções para produtividade em cada um dos ambientes conduziu a performances não negativamente associadas, indicando que a seleção sob baixo $\mathrm{N}$ pode não ser prejudicial para a produtividade sob alto $\mathrm{N}$.

O Centro Nacional de Pesquisa em Milho e Sorgo possui um programa iniciado em 1987 que resultou no Sintético Elite NT, que é oriundo de um dialélico das dez melhores linhagens deste centro. A terceira recombinação das plantas provenientes deste dialélico foi feita simultaneamente em solo fértil e pobre em $\mathrm{N}$, e as $10 \%$ melhores famílias foram recombinadas duas vezes em solo fértil e posteriormente em 
solo pobre em $\mathrm{N}$ na densidade de cem mil plantas/ha. Nesta última recombinação foram polinizadas, manualmente, plantas que apresentavam sincronia no florescimento (Santos et al., 1998). Estes autores avaliaram famílias de meios irmãos de Sintético Elite as quais apresentaram uma produção $27 \%$ menor em solo pobre em N, quando comparada com a produção em solo fértil. A testemunha intercalar BR 106, selecionada para solos férteis, apresentou queda na produção de $65 \%$ no solo pobre, e no solo fértil, produziu menos que o Sintético Elite. Os resultados indicaram a existência de variabilidade para a continuidade do programa em solos pobres, e que a seleção para sincronia no florescimento pode aumentar a eficiência em programas de melhoramento. Esta sincronia indica elevada força do dreno, ou seja, maior capacidade de translocação de biomassa para os grãos.

Um outro material eficiente no uso do $\mathrm{N}$, recentemente lançado, é a variedade Sol da Manhã Nitroflint. Machado (1997) avaliou variedades locais brasileiras e esta variedade melhorada para eficiência no uso do Nitrogênio, que é originada do ESALQ VF7 que sofreu 3 ciclos de seleção massal, 1 ciclo de seleção entre e dentro de famílias de meios irmãos, 1 ciclo de seleção de famílias de irmãos germanos e 1 ciclo de seleção de famílias endogâmicas $S_{1}$. É uma população de grãos duros e semi duros de endosperma alaranjado com segregação para branco e predomínio dos germoplasma Cateto, Eto e Duros do Caribe, formada a partir de 36 populações da América Central e do Sul. A variedade Nitroflint se mostrou produtiva em ambientes com e sem limitação para $\mathrm{N}$ e se destacou em conteúdo de nitrogênio nos grãos e na planta toda, peso do sabugo e a relação peso de espiga e matéria seca. Os componentes da eficiência $\left(\mathrm{P}_{\mathrm{g}} / \mathrm{N}_{\mathrm{s}}\right)$ e de absorção $\left(\mathrm{N}_{\mathrm{tp}} / \mathrm{N}_{\mathrm{s}}\right)$ foram eficientes para caracterizar as variedades no ambiente com nível baixo de $\mathrm{N}$, enquanto que os componentes de utilização $\left(\mathrm{P}_{\mathrm{g}} / \mathrm{N}_{\mathrm{tp}}\right)$ e de translocação foram eficientes para caracterizar as variedades nos níveis alto e baixo de $\mathrm{N}$.

Muitos autores procuram caracterizar o que seria a planta ideal para um determinado objetivo, a qual se denomina "ideótipo". Na Figura 3 estão alguns ideótipos relacionados à EUN, que foram recomendados, utilizados ou são baseados em associações com produtividade. 


\begin{tabular}{|c|c|c|}
\hline Ideótipo & Vantagem almejada ou obtida & Referência. \\
\hline $\begin{array}{l}\text { Absorção intensa e prolongada de } \mathrm{N} \text {, com } \\
\text { elevada translocação }\end{array}$ & Alto teor de proteína no grão & $\begin{array}{l}\text { Pollmer } \\
(1979)\end{array}$ \\
\hline $\begin{array}{l}\text { Absorção de } \mathrm{N} \text { durante o enchimento dos } \\
\text { grãos e manutenção de folhas verdes mais } \\
\text { tempo para fotossíntese }\end{array}$ & n maior EUN & $\begin{array}{lll}\text { Ma } & \& & \text { Dwyer } \\
(1998) & \end{array}$ \\
\hline $\begin{array}{l}\text { Maior absorção, alto teor de } \mathrm{N} \text { foliar e } \\
\text { maior fotossíntese por unidade de } \mathrm{N} \text { foliar }\end{array}$ & Alta & $\begin{array}{l}\text { McCculloug et al. } \\
(1994 a)\end{array}$ \\
\hline Eficiência na utilização do $\mathrm{N}$ & \begin{tabular}{llll|}
$\begin{array}{l}\text { Produtividade em } \\
\text { deficiência de } \mathrm{N}\end{array}$ & & \\
\end{tabular} & Moll et al. (1982) \\
\hline Eficiência & $\begin{array}{l}\text { Produtividade em solos com alto } \\
\text { nível de } \mathrm{N}\end{array}$ & Moll et al. (1982) \\
\hline $\begin{array}{l}\text { Elevada sincronia no florescimento em solo } \\
\text { com deficiência de } \mathrm{N}\end{array}$ & $\begin{array}{l}\text { Produtividade em solos com e } \\
\text { sem deficiência de } \mathrm{N}\end{array}$ & Santos et al. (1998) \\
\hline $\begin{array}{l}\text { Prolificidade sob baixo } \mathrm{N} \text { ou eficiência } \\
\text { média nos ambientes de alta e baixa } \\
\text { disponibilidade de } \mathrm{N}\end{array}$ & $\begin{array}{l}\text { Produtividade somente sob alta } \\
\text { disponibilidade de } \mathrm{N}\end{array}$ & Moll et al. (1987) \\
\hline Produtividade em solo com deficiência de $\mathrm{N}$ & $\begin{array}{l}\text { Produtividade em solos com e } \\
\text { sem deficiência de } \mathrm{N}\end{array}$ & $\begin{array}{l}\text { Lafitte \& } \\
\text { Edmeades (1994a) }\end{array}$ \\
\hline $\begin{array}{l}\text { Altura, sincronia no florescimento, número } \\
\text { de grãos por espiga, índices de colheita e de } \\
\text { colheita de } \mathrm{N} \text { e eficiência na utilização do } \mathrm{N} \\
\text { para produção de grãos }\end{array}$ & $\begin{array}{llll}\begin{array}{l}\text { Produtividade em } \\
\text { deficiência de } \mathrm{N}\end{array} & & & \\
\text { solo } & \text { com }\end{array}$ & $\begin{array}{l}\text { Lafitte \& } \\
\text { Edmeades (1994a) }\end{array}$ \\
\hline $\begin{array}{l}\text { Produtividade sob baixo e alto } \mathrm{N} \text {, alto teor } \\
\text { de clorofila, maior altura e menor } \\
\text { senescência sob baixo } \mathrm{N}\end{array}$ & $\begin{array}{l}\text { Produtividade em solos pobres } \\
\text { sem prejuízo da produtividade em } \\
\text { solos férteis para } \mathrm{N}\end{array}$ & $\begin{array}{l}\text { Lafitte \& } \\
\text { Edmeades (1994b) }\end{array}$ \\
\hline Absorção de $\mathrm{N}$ antes da floração & $\begin{array}{l}\text { Produtividade em solos com alto } \\
\text { teor de } \mathrm{N}\end{array}$ & $\begin{array}{l}\text { Lafitte \& } \\
\text { Edmeades (1994c) }\end{array}$ \\
\hline azão raiz parte aérea & $\begin{array}{l}\text { Produtividade em solos com e } \\
\text { sem deficiência de } \mathrm{N}\end{array}$ & $\begin{array}{l}\text { Lafitte \& } \\
\text { Edmeades (1994c) }\end{array}$ \\
\hline $\begin{array}{l}\text { Seleção somente para produtividade em } \\
\text { solos pobres em N }\end{array}$ & \begin{tabular}{llll|}
$\begin{array}{l}\text { Produtividade em } \\
\text { deficiência de } \mathrm{N}\end{array}$ & & \\
\end{tabular} & $\begin{array}{l}\text { Bänziger et al. } \\
(1997)\end{array}$ \\
\hline $\begin{array}{l}\text { Índice Smith-Hazel para sincronia } \\
\text { florescimento, prolificidade, teor } \\
\text { clorofila e senescência lenta }\end{array}$ & 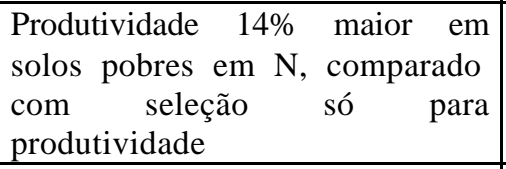 & $\begin{array}{l}\text { Bänziger } \\
(1997)\end{array}$ \\
\hline Elevado teor de $\mathrm{N}$ no grão e na planta toda & $\begin{array}{l}\text { Produtividade em solos com e } \\
\text { sem deficiência de } \mathrm{N}\end{array}$ & Machado (1997) \\
\hline $\begin{array}{l}\text { Absorção de } \mathrm{N} \text {, partição de } \mathrm{C} \text { e } \mathrm{N} \text { para os } \\
\text { grãos e elevado teor de } \mathrm{N} \text { nos grãos em } \\
\text { solos pobres em } \mathrm{N}\end{array}$ & \begin{tabular}{llll|}
$\begin{array}{l}\text { Produtividade em } \\
\text { deficiência de } \mathrm{N}\end{array}$ & & & \\
solo & com
\end{tabular} & Lafitte et al. (1997) \\
\hline Aumento na produção de fotoassimilados & $\begin{array}{l}\text { Elevação na produtividade devida } \\
\text { ao aumento na absorção de } \mathrm{N}\end{array}$ & Moll et al. (1994) \\
\hline $\begin{array}{l}\text { Acúmulo foliar de nitrato, atividade de } \\
\text { enzimas de assimilação de } \mathrm{N}\end{array}$ & \begin{tabular}{llll|}
$\begin{array}{l}\text { Produtividade em solo com } \\
\text { deficiência de } \mathrm{N}\end{array}$ & & \\
\end{tabular} & Hirel et al. (2001) \\
\hline $\begin{array}{l}\text { Capacidade do sistema radicular de explorar } \\
\text { maior volume de solo }\end{array}$ & $\begin{array}{l}\begin{array}{l}\text { Produtividade em solo com } \\
\text { deficiência de } \mathrm{N}\end{array}\end{array}$ & $\begin{array}{lll}\text { Gastal \& Lemaire } \\
(2002)\end{array}$ \\
\hline
\end{tabular}

Figura 3 - Ideótipos relacionados à EUN em milho. 
Observando estes ideótipos, encontramos algumas coincidências, tais como as características dos milhos Sintético Elite (Santos et al, 1998) e Across 8328 NB (Lafitte \& Edmeades, 1994 a). Estes materiais tem elevada sincronia no florescimento sob baixo $\mathrm{N}$, ou índice de colheita elevado. A sincronia no florescimento inclusive é um indicador de maior translocação de biomassa para os grãos. O Nitroflint possui alto teor de $\mathrm{N}$ nos grãos e isto também foi associado a estabilidade produtiva de variedades locais no trabalho de Lafitte et al., (1997). Algumas diferenças são também notadas, tais como por exemplo: a eficiente absorção de $\mathrm{N}$ é indicada como importante para solos pobres em N por Lafitte et al. (1997), mas Moll et al. (1992), já indicam esta eficiência como sendo importante para produtividade em solos ricos em N. Outra diferença se observa na prolificidade, que foi indicada para solos apenas férteis por Moll et al (1987), mas aparece como uma das características mais importantes no índice de seleção para solos pobres, no trabalho de Bänziger et al. (1997).

Para que características secundárias sejam utilizadas em melhoramento, é importante conhecer informações genéticas a respeito destas variáveis. Com relação à EUN algumas informações genéticas constam na Figura 4.

\begin{tabular}{|l|l|l|}
\hline Variável relacionada à EUN & Informação genética & Referência \\
\hline $\begin{array}{l}\text { Absorção até o florescimento, } \\
\text { após o florescimento e total, e } \\
\text { translocação de N }\end{array}$ & $\begin{array}{l}\text { CGC e CEC significativas. Importância relativa dos } \\
\text { fatores pode variar nos genótipos e ambientes }\end{array}$ & $\begin{array}{l}\text { Pollmer et } \\
\text { al. (1979) }\end{array}$ \\
\hline $\begin{array}{l}\text { Altura da planta e da espiga e } \\
\text { peso de cem sementes sob } \\
\text { níveis alto e baixo de N }\end{array}$ & $\begin{array}{l}\text { Herança aditiva (existiu correlação entre as performances } \\
\text { das linhas e de seus híbridos) }\end{array}$ & $\begin{array}{l}\text { Lafitte \& } \\
\text { Edmeades } \\
(1995)\end{array}$ \\
\hline $\begin{array}{l}\text { Produtividade em níveis alto e } \\
\text { baixo de N }\end{array}$ & $\begin{array}{l}\text { Herança não aditiva (não existiu correlação entre a a } \\
\text { performance das linhas e a de seus híbridos) }\end{array}$ & $\begin{array}{l}\text { Lafte } \\
\text { Edmeades } \\
(1995)\end{array}$ \\
\hline $\begin{array}{l}\text { Produtividade, teor de clorofila, } \\
\text { área roliar e } \\
\text { senescência foliar }\end{array}$ & Herdabilidade maior sob baixo teor de N no solo & $\begin{array}{l}\text { Lafitte } \\
\text { Edmeades } \\
(1994 a)\end{array}$ \\
\hline $\begin{array}{l}\text { Absorção de N, peso de grãos e } \\
\text { matéria seca total }\end{array}$ & Heterose & $\begin{array}{l}\text { Moll et al. } \\
(1994)\end{array}$ \\
\hline $\begin{array}{l}\text { Aumento do teor de N nos } \\
\text { grãos e da produtividade }\end{array}$ & $\begin{array}{l}\text { Xenia. Polinização de milho de reduzida EUN, com pólen } \\
\text { de milho de alta EUN, resultou em aumento da força do } \\
\text { dreno e absorção de N do solo, aumentando a EUN }\end{array}$ & $\begin{array}{l}\text { Tsai et al. } \\
(1991 b)\end{array}$ \\
\hline
\end{tabular}

Figura 4 - Parâmetros genéticos de variáveis relacionadas à EUN em milho. 


\subsection{Metabolismo da assimilação do nitrogênio}

A assimilação do nitrogênio pelas plantas compreende a transformação do nitrogênio mineral em nitrogênio orgânico.

Normalmente a forma predominante nos solos e o nitrato que é absorvido pelas plantas e reduzido a amônio, com a atuação seqüencial das enzimas nitrato redutase (NR) e nitrito redutase (Nir). O amônio proveniente da redução do nitrato é assimilado pelo ciclo glutamina sintetase/glutamato sintase (GS/GOGAT). A GS sintetiza glutamina a partir de amônio e glutamato, e a GOGAT transfere o grupo amida da glutamina para o 2- oxoglutarato formando dois glutamatos. Depois que o nitrogênio entrou na biosfera como glutamina e glutamato todas as demais biomoléculas nitrogenadas serão derivadas destes dois aminoácidos. A via GS/GOGAT também incorpora o amônio proveniente da absorção do solo, da fotorrespiração e catabolismos de aminoácidos e fenilpropanóides. Como o nitrito e o amônio podem ser tóxicos para as plantas, todo o processo, desde a redução do nitrato até a formação de glutamina, ocorre no mesmo local, podendo ser nas raízes ou na parte aérea (Lea \& MorotGaudry, 2001).

A despeito de muitos estudos bioquímicos e da disponibilidade de cDNA e anticorpos para todas as enzimas da assimilação do $\mathrm{N}$ em plantas, a questão de quais enzimas são limitantes e restringem a efetividade do esforço para aumentar a eficiência no uso do $\mathrm{N}$ ainda não é resolvida (Temple et al., 1998).

A GS é uma das mais velhas e funcionais em todas as formas de vida, e a evolução dos procariontes para as plantas superiores deve ter refinado as funções desta enzima, para fornecer $\mathrm{N}$ reduzido para todo o metabolismo (Cren \& Hirel, 1999). Segundo estes autores, o estudo da diversidade dos modos de expressão da GS é um dos mais promissores para o entendimento da assimilação do amônio e, mais genericamente, para o melhoramento da EUN. Existem dois tipos de GS em plantas, a cloroplástica e a citoplásmica, denominadas respectivamente GS2 e GS1. A GS2 é codificada por um gene por genoma haplóide, o qual codifica um peptídeo com massa molecular de 43 a $45 \mathrm{kDa}$, dependendo da espécie, que se combina em um octâmero para formar a enzima ativa. No N-terminal existe o peptídeo sinal que direciona para o 
cloroplasto. A GS2 pode ser regulada por nitrato e luz (Cren \& Hirel, 1999). Fiitocromo e o criptocromo participam da expressão dependente de luz, que deve envolver ainda o sistema ferridoxina/tioredoxina (Choi et al, 1999).

Estudos em raiz de milho detectaram uma família de 5 genes codificando para a GS1, com expressões tecido específicas. O GS1-2 é expresso em tecido vascular, os GS1-1 e GS1-5 no córtex e os GS1-3 e GS1-4 são expressos em todos os tecidos. Além desta expressão tecido específica, os genes GS1-1 e GS1-5 são ativados por amônio enquanto que GS1-3 e GS1-4 são inibidos por este cátion. Ainda em milho foi identificada uma GS1 nos pedicelos dos grãos que é distinta das encontradas em folhas e raízes, sugerindo que em órgãos de acúmulo a assimilação de amônio possui regulação dependente do tecido e do desenvolvimento (Cren \& Hirel, 1999). A GS 1 é um octâmero formado por subunidades de massa molecular entre 39 e 45 kDa (Cren \& Hirel, 1999).

Em plantas $\mathrm{C} 3$ as formas citoplásmicas estão localizadas principalmente nas raízes, mas em plantas C4 a parte aérea pode conter quantidades equivalentes de GS1 e GS2. O milho foi enquadrado por Mc Nally et al. (1983) no grupo de plantas que contém $30 \%$ ou mais de GS2 na parte aérea.

O papel fisiológico das isoformas de GS não é completamente esclarecido. Tem sido proposto que a GS2 assimila o amônio proveniente da redução do nitrato e reassimila o amônio da fotorrespiração, enquanto que a GS1 participa principalmente da assimilação nas raízes e também na remobilização de nitrogênio, como ocorre por exemplo na senescência. Inclusive a ocorrência da GS 1 em floema reforça este envolvimento (Lan et al, 1996). A forma citoplásmica pode também participar da produção de prolina durante estresse de seca (Brugiére et al., 1999).

Antes de 1974 acreditava-se que o amônio era assimilado em plantas superiores pela glutamato desidrogenase $(\mathrm{GDH})$, mas hoje está bem estabelecido que esta função é exercida pelo ciclo GS/GOGAT. A GDH catalisa a aminação reversível do 2oxoglutarato e é um hexâmero de subunidades de 42-45 kDa e é localizada em mitocôndria (forma NADH dependente) e cloroplasto (forma NADPH dependente). O papel atualmente creditado a GDH é o de desaminar o glutamato, principalmente sob 
estresses, embora sua participação na assimilação ainda seja proposta (Lea \& Miflin, 1974; Bechtold et al, 1998). A atividade da GDH aumenta durante a senescência (Smart, 1994) e pode ser regulada por fitohormônios, estresses de temperatura, água, metais pesados, herbicidas e também por deficiência de nitrogênio. Osuji et al (1998) demonstraram que a isomerização de 28 formas de GDH mitocondrial em milho pode ser modulada pela deficiência nutricional de $\mathrm{N}, \mathrm{P}$ e $\mathrm{K}$, sugerindo que os padrões de isomerização podem servir como ferramentas bioquímicas para o diagnóstico do estado nutricional.

A atividade da NR é modulada por uma séria de fatores tais como o nitrato (Redinbaugh \& Campbell,1993), luz, inclusive o tempo de exposição (Nicholas et al, 1976), idade fisiológica da folha (Harper \& Hagman, 1972), proteína 14-3-3, glutamina, carboidratos e hormônios (Lea \& Morot-Gaudry, 2001). Esta enzima possui uma regulação multifatorial atuando em diferentes níveis, incluindo transcrição, tradução, modificações pós traducionais reversíveis e degradação (Lea \& MorotGaudry, 2001). A atividade desta enzima tem sido proposta como um critério auxiliar para a seleção de germoplasma eficiente no uso do Nitrogênio e de maior produtividade. Feil et al. (1993) encontraram correlação positiva e significativa entre a atividade da NR em plântulas e a produção de grãos em milho. Eichelberger et al. (1989) entretanto, estudando vários ciclos de seleção divergente para alta e para baixa atividades da NR, concluíram que, embora tenha havido eficiência nas seleções, a seleção para a alta atividade de nitrato redutase não proporcionou aumento na produtividade.

Purcino et al. (1990), comparando genótipos antigos e modernos de milho, observaram que materiais com alta atividade da NR tendem a ser responsivos à adubação nitrogenada e eficientes no uso do $\mathrm{N}$ em ambientes com baixo teor deste nutriente, enquanto que materiais que só produzem bem quando adubados (ineficientes - responsivos) tendem a ter baixa atividade da NR.

Machado (1997) verificou que as atividades da NR e GS não foram eficientes para discriminar variedades de polinização aberta quanto a EUN, mas encontrou que esta capacidade discriminatória foi possível em famílias endogâmicas S1, e que, 
portanto, podem ser usadas como parâmetros bioquímicos em programas de seleção genética.

Estudos com super expressão de NR indicam que o papel funcional desta enzima é espécie específico, e que mais estudos são necessários para determinar sua importância em cereais. Em Nicotiana plumbaginifolia a super expressão constitutiva resultou em menor teor de nitrato, mas não houve incremento no $\mathrm{N}$ total ou na biomassa. Contrariamente, em Arabidopsis thaliana a super expressão da NR elevou em 200\% o teor de proteína. A manipulação das enzimas da assimilação do $\mathrm{N}$ e do transporte de aminoácidos podem aumentar a EUN e ainda melhorar a qualidade nutricional das plantas (Singh \& Jaiwal, 1999).

Reggiani et al. (1999) estudaram linhagens de milho de origens diferentes e encontraram variação para os parâmetros da cinética de absorção do nitrato e para as atividades da GS e Fd-GOGAT, identificando inclusive linhas com alta razão Vmax/Km e altas atividades enzimáticas, que serão cruzadas em esquema dialélico.

Estudos preliminares indicam que as manipulações de GS e asparagina sintetase podem aumentar a EUN. Tabaco com super expressão de GS1 em células do mesófilo (normalmente em tabaco esta isoforma só ocorre no floema) cresceu mais do que o tipo selvagem. A co-supressão das formas cloroplástica e citoplásmica, ao contrário, acarretou redução no crescimento. Tabaco transformado para alta expressão da asparagina sintetase apresentou aumento de cem vezes no teor de asparagina livre nas folhas (Lam et al., 1995).

Álamo transformado para super expressão de GS1 apresentou maior teor de proteína e clorofila. Além disto, em dois meses de crescimento, as plantas transformadas apresentaram altura 76\% maior que as plantas controle. Após seis meses as transformadas foram $21,3 \%$ maiores que as não transformadas, sugerindo que a EUN pode ser melhorada em árvores com manipulação genética (Gallardo et al, 1999).

Milhos de diversas eras nos EUA foram estudados, com cultivo sob $\mathrm{N}$ alto e baixo, para verificar se o aumento linear na produção destes híbridos, pode ser explicado por diferenças em atividades de enzimas da assimilação do $\mathrm{N}$ e do carbono. 
O resultado mostrou que da década de 1930 até a de 1970, o melhoramento para aumento da produtividade elevou indiretamente a atividade da fosfoenolpiruvato carboxilase e o estado de ativação da NR e da sacarose fosfato sintase. Dos anos 80 até os 90 esta tendência não se observou, indicando que nestas duas últimas décadas o aumento de produtividade não pode ser explicado por adicional redução do nitrato, assimilação primária do carbono e metabolismo da sacarose. A GS2 não foi correlacionada com as eras nem com os níveis de N, mas a GS1 apresentou valores maiores nas plantas supridas com menos N, e ainda nestas plantas a GS1 apresentou correlação negativa com a atividade da NR, indicando seu papel na remobilização. A atividade da $\mathrm{GH}$ declinou após a década de 70 , no nível baixo de $\mathrm{N}$ e no nível alto a GDH se correlacionou negativamente com a GS2 (Purcino et al., 1998).

\subsection{Deficiência de nitrogênio e fotoinibição}

Fotoinibição é a redução da eficiência fotossintética devido ao excesso de luz ao qual um organismo fotossintetizante está exposto. É um fenômeno comum a todos os organismos que oxidam a água para fazer fotossíntese. Esta enorme capacidade de oxidação gera também espécies tóxicas de $\mathrm{O}_{2}$, tais como oxigênio singlet, peróxidos e superóxidos que são os principais agentes danosos da fotoinibição.

Diversos mecanismos existem para a fotoproteção e podem ser divididos em três estratégias que são a evitar o dano, suprimir os radicais livres e espécies reativas de oxigênio e reparar os danos ocorridos (Niyogi, 1999).

As enzimas superóxido dismutase (SOD), catalase (CAT), glutationa redutase (GR) e ascorbato peroxidase (Asc-Px) estão envolvidas no processo de fotoproteção e também na proteção do metabolismo contra espécies tóxicas de oxigênio geradas em outras vias metabólicas, tais como a respiração escura.

Del Longo et al. (1993) comparou cultivares de milho tolerante e sensível à seca durante a exposição ao estresse hiperosmótico e hiperoxigênico, e demonstrou que a cultivar de milho tolerante à seca manteve alta atividade de SOD, CAT, GR e Asc-Px enquanto que a cultivar sensível mostrou declínio nestas atividades. A tolerante apresentou também menores razões SOD/CAT, SOD/Asc-Px e SOD/ GR do 
que a sensível, que apresentou danos que indicaram maior peroxidação de lipídeos, destruição de clorofila e carotenóides e redução no nível de grupos sulfidrilas em proteínas.

Tem sido demonstrado que a deficiência de nitrogênio pode aumentar a sensibilidade à fotoinibição. Lu \& Zhang (2000) encontraram resultados indicando que a maior sensibilidade à fotoinibição, de milho deficiente em $\mathrm{N}$, está associada com aumento do acúmulo de centros de reação do PSII (fotossistema II) inativados, diminuição da capacidade de supressão não fotoquímica e aumento da fração do estado reduzido do aceptor primário de elétrons do PSII, o sítio $Q_{\mathrm{A}}$.

Do exposto, deduz-se que existe variação em milho para as atividades de enzimas antioxidantes e que esta variação pode estar relacionada com tolerância ao estresse. Uma vez que estas enzimas participam da fotoproteção e que a fotoinibição é relacionada com disponibilidade de $\mathrm{N}$, é razoável estudar o comportamento destas enzimas em milhos contrastantes na EUN e estressados por deficiência de N. 


\section{MATERIAL E MÉTODOS}

\subsection{Experimentos de campo}

\subsubsection{Experimento 1}

Foram usadas uma linha $\mathrm{S}_{4}$ e sete linhas $\mathrm{S}_{5}$ de milho (Zea mays L.), desenvolvidas na Universidade Federal Rural do Rio de Janeiro e dois controles. Estas linhas foram selecionadas em um experimento prévio como sendo contrastantes para variáveis relacionadas à EUN, tais como teor de clorofila, sincronia no florescimento e prolificidade. Os dois controles foram obtidos da Embrapa Milho e Sorgo. Um controle foi a cultivar BR 106 e a outra foi a população Sintético Elite NT, a qual vem sendo selecionada para alta produtividade em solos pobres em N (Santos et al., 1998). A linha $S_{4}$, numerada como 13 , e as linhas $S_{5}$, numeradas como 2, 3, 4, 10 e 17, foram originadas do híbrido comercial AG 311 da empresa de sementes Agroceres, enquanto as linhas S, numeradas como 5 e 6 , foram originadas do híbrido comercial AG 302 da mesma empresa.

O experimento foi conduzido na Estação Experimental Anhembi da Escola Superior de Agricultura "Luiz de Queiroz" - Universidade de São Paulo (ESALQ/USP), Piracicaba, SP. Foi escolhido um local com elevada produtividade de milho em anos anteriores. O solo é um Latossolo Amarelo do qual a análise dos primeiros $20 \mathrm{~cm}$ de profundidade indicou: $\mathrm{pH}-5,5$; matéria orgânica - $29 \mathrm{~g} \mathrm{dm}^{-3}$; $\mathrm{P}$ $58 \mathrm{mg} \mathrm{dm}{ }^{-3} ; \mathrm{K}-6,1 \mathrm{mmol}_{\mathrm{c}+} \mathrm{dm}^{-3} ; \mathrm{Ca}-36 \mathrm{mmol}_{\mathrm{c}+} \mathrm{dm}^{-3} ; \mathrm{Mg}^{-2} 2 \mathrm{mmol}_{\mathrm{c}+} \mathrm{dm}^{-3} ; \mathrm{Al}-0$ mmol $_{\mathrm{c}+} \mathrm{dm}^{-3} ; \mathrm{H}+\mathrm{AL}-28 \mathrm{mmol}_{\mathrm{c}+} \mathrm{dm}^{-3}$.

O experimento foi plantado no dia 24 de janeiro de 2000 com os tratamentos fatoriais das oito linhas mais os dois controles combinados com dois níveis de $\mathrm{N}$ (10 e $110 \mathrm{~kg} \mathrm{~N} \mathrm{ha}{ }^{-1}$ na forma de uréia), com 4 repetições em um ensaio em blocos ao acaso. 
As parcelas consistiam de uma linha de $2 \mathrm{~m}$ de comprimento, com espaçamento de 1 $\mathrm{m}$ entre linhas e de 0,2 m entre plantas. Dentro das linhas utilizou-se uma bordadura de 1,2 m entre as parcelas. Utilizou-se irrigação sempre que necessário.

A sincronia no florescimento foi o número de dias entre a ocorrência de emergência das anteras em $50 \%$ das plantas e a ocorrência de emergência dos estilos em $50 \%$ das plantas na parcela. A prolificidade foi a razão entre o número total de espigas e o número de plantas da parcela. A massa de cem grãos foi medida em uma amostra em cada parcela. O número de grãos por planta foi calculado com base na massa de cem grãos. O número de folhas verdes abaixo da espiga mais alta, que será denominado como "número de folhas verdes", foi contado em quatro plantas por parcela, 21 dias após o florescimento masculino da parcela. O teor de clorofila foi determinado com o equipamento portátil SPAD 502 (Minolta, Ramsay, New Jersey, EUA), usando duas medidas em cada folha da espiga de 10 plantas por parcela, 14 dias após o florescimento masculino médio do experimento. Partes aéreas completas de quatro plantas por parcela foram colhidas na maturidade. Estas plantas foram secadas a $60{ }^{\circ} \mathrm{C}$ por 72 horas e usadas para análise do teor de $\mathrm{N}$ nos grãos e no resto da planta, usando o método Kieldal, no laboratório de análises de solos e plantas da ESALQ/USP. O N total por planta foi calculado com a soma entre as quantidades de $\mathrm{N}$ nos grãos e no resto da planta. A eficiência na utilização de $\mathrm{N}$, definida por Moll et al. (1982) como a produção de grãos por unidade de $\mathrm{N}$ em toda a parte aérea, foi calculada como a massa (g) de grãos das quatro plantas dividida pelo total de $\mathrm{N}$ (g) da mesma amostra. Esta eficiência indica a habilidade da planta de produzir grãos usando a quantidade de $\mathrm{N}$ acumulada nos tecidos da parte aérea. Estas quatro plantas também foram usadas para calcular o índice de colheita como a razão entre a massa de grãos e a massa de toda a parte aérea seca.

A análise de variância foi feita usando o teste F. Para as variáveis que apresentaram significância para a interação genótipo $\mathrm{x}$ nitrogênio, foi feito teste $\mathrm{F}$, com um grau de liberdade, para testar o efeito das doses de $\mathrm{N}$ em cada genótipo. Também nestas variáveis foi feito teste de médias em cada nível de $\mathrm{N}$, usando o teste de Tukey ao nível de $5 \%$ de probabilidade. A variável número de folhas verdes foi transformada 
para a raiz do valor acrescido de 0,5 e a sincronia no florescimento foi transformada para a raiz do valor acrescido de 7,5. Foi calculada a correlação simples entre a produtividade de grãos e as demais variáveis, em cada nível de $\mathrm{N}$, usando os dados das parcelas das linhas e dos controles.

\subsubsection{Experimento 2}

Foram utilizadas as linhas numeradas como 2, 3, 4, 5, 6 e 10 e os dois controles descritos no experimento 1. Foram utilizados também os 15 híbridos simples originados dos cruzamentos dialélicos entre estas linhas. O experimento foi conduzido na Estação Experimental Anhembi da Escola Superior de Agricultura "Luiz de Queiroz" - Universidade de São Paulo (ESALQ/USP), Piracicaba, SP. Foi escolhido um local com produtividades prévias de milho inferiores às do local utilizado no experimento 1. O solo é um Latossolo Amarelo do qual a análise dos primeiros $20 \mathrm{~cm}$ de profundidade indicaram: $\mathrm{pH}-4,4$; matéria orgânica - $26 \mathrm{~g} \mathrm{dm}^{-3} ; \mathrm{P}-63 \mathrm{mg} \mathrm{dm}{ }^{-3} ; \mathrm{S}$ $\left(\mathrm{SO}_{4}\right)-21 \mathrm{mg} \mathrm{dm}{ }^{-3} ; \mathrm{K}-5,5$ mmolc dm ${ }^{-3} ; \mathrm{Ca}-14$ mmolc dm${ }^{-3} ; \mathrm{Mg}-7$ mmolc dm ${ }^{-3} ; \mathrm{Al}$ -6 mmolc $\mathrm{dm}^{-3}$.

O plantio foi realizado no dia 25 de fevereiro de 2001 e utilizou-se irrigação sempre que necessário.

O terreno foi dividido em 6 blocos e em cada um deles foi plantado separadamente uma repetição do fatorial das seis linhas combinadas com duas doses de $\mathrm{N}$ (10 e $130 \mathrm{~kg} \mathrm{~N} \mathrm{ha}^{-1}$ na forma de uréia) e uma repetição do fatorial dos 15 híbridos mais os dois controles combinados com as mesmas duas doses de N. As parcelas consistiram de uma linha de $5 \mathrm{~m}$ de comprimento, com um espaçamento entre linhas de 0,9 m e 0,2 m entre as plantas. Dentro das ruas existiu uma bordadura de 1,6 m entre as parcelas. Entre as repetições de linhas e híbridos, em cada bloco, foram utilizadas três linhas de bordadura. Foram analisadas as mesmas variáveis do experimento 1 e mais a área foliar da folha da espiga mais alta, que foi estimada em quatro plantas por parcela, pela multiplicação do comprimento pela largura e pelo fator 0,75, como descrito no trabalho de Giauffret et al. (1997). O número de folhas verdes 
foi medido 14 dias após o florescimento masculino de cada parcela e o teor de clorofila foi medido 25 dias após o florescimento masculino médio do experimento.

Os dados das linhas e dos controles foram submetidos à mesma análise estatística do experimento 1, com diferença apenas na transformação da variável sincronia no florescimento, que foi feita para raiz do valor acrescido de 4,5.

Os resultados obtidos com os híbridos foram utilizados para a análise dialélica pelo método 4, modelo 1, de Griffing (1956). As interações das capacidades de combinação com os níveis de nitrogênio foram calculadas pelo método citado por Vencovsky e Barriga (1992). A importância relativa entre as capacidades geral e específica foi calculada seguindo a expressão proposta por Baker (1978). Com os híbridos também foram calculadas, em cada nível de $\mathrm{N}$, a correlação simples entre a produtividade de grãos e as demais variáveis e a correlação residual, na qual foram retirados os efeitos genotípicos e dos blocos. Além das mesmas transformações feitas para as linhas, nos híbridos transformou-se também a variável $\mathrm{N}$ total para raiz do valor.

\subsection{Experimentos em casa de vegetação}

\subsubsection{Experimento 1}

As três linhas denominadas 2, 4 e 6, descritas no experimento 1 de campo, e seus três híbridos 24, 26 e 46 foram cultivadas, em hidroponia em areia em potes de 1,2 L de capacidade. Utilizou-se solução de Hoagland modificada e foi cultivada uma planta por pote. Os nitratos de cálcio e de potássio da solução original foram suprimidos. O cálcio e o potássio foram supridos por quantidades equivalentes às originais com cloreto de cálcio e sulfato de potássio. Foram utilizados os níveis de 1 e $10 \mathrm{mM}$ de nitrogênio na forma de nitrato de amônio. Previamente foi determinado o volume de solução que deve ser aplicado sobre a areia para que toda a solução nela contida seja substituída por nova. Este volume foi determinado aplicando-se água destilada sobre o pote com areia contendo solução nutritiva, enquanto se monitorava a condutividade elétrica da solução percolada. O volume necessário para renovação foi 
considerado equivalente ao volume de água para retirar toda a solução, que foi de 1,2 L. A cada 4 dias a solução foi renovada. O suprimento de água foi efetuado com corda de polipropileno com uma ponta conectada na areia e outra em um pote de água, para que, por capilaridade, ocorresse a substituição da água evapotranspirada. O plantio foi feito no dia 17 de janeiro de 2001 e após três dias ocorreu a emergência das plântulas. A casa de vegetação é localizada no campus da ESALQ-USP e as médias das temperaturas mínimas e máximas foram 23 e $33{ }^{\circ} \mathrm{C}$, respectivamente. $\mathrm{O}$ ensaio foi em blocos ao acaso com quatro repetições. Aos 25 dias após a emergência das plântulas, foram estimadas a fotossíntese líquida com o equipamento LI 6400 (LI-COR, Inc. Lincoln, Nebraska, USA), a eficiência máxima do fotossistema II com o equipamento PAM-2000 (Walz, Alemanha) e o teor de clorofila com o equipamento SPAD 502 (Minolta, Ramsay, New Jersey, EUA). Aos 32 dias após a emergência, foi feita a contagem das as folhas verdes com lígula visível e das folhas senescentes, para determinação da porcentagem de folhas senescentes, e as plantas foram colhidas para determinação do peso da matéria seca e amostras de raízes foram armazenadas a - 70 ${ }^{\circ} \mathrm{C}$ para as seguintes análises bioquímicas: quantificação espectrofotométrica das atividades das enzimas catalase (CAT, EC 1.11.1.6) e glutationa redutase (GR EC 1.6.4.2); separação de isoformas por eletroforese em gel de poliacrilamida não desnaturante das enzimas CAT, GR e superóxido dismutase (SOD, EC 1.15.1.1). As atividades enzimáticas foram determinadas em três blocos, as demais variáveis quantitativas foram determinadas nos quatro blocos e os géis foram repetidos em pelo menos dois blocos.

A motivação teórica para o estudo de enzimas antioxidantes foi, inicialmente, baseada na revisão de literatura sobre fotoinibição, portanto as folhas seriam o material principal da investigação. Contudo, nas análises prévias verificou-se, nas raízes, grande efeito do nitrogênio na atividade da GR e, portanto, optou-se por seguir o trabalho apenas nas raízes.

As raízes foram maceradas em almofariz, em presença de nitrogênio líquido, até a formação de uma farinha homogênea. Esta farinha foi vertida com nitrogênio líquido para tubo de centrífuga e, em seguida, foi adicionada solução preparada 
conforme Bechtold et al. (1998) (com exceção do EDTA que foi suprimido). Esta solução foi $100 \mathrm{mM}$ de TRIS-HCl, pH 7,8, $1 \mathrm{mM}$ de DTT, 10\% (v/v) de glicerol e $0,2 \%(\mathrm{p} / \mathrm{v})$ de PVPP. $\mathrm{O}$ extrato foi centrifugado à $4^{\circ} \mathrm{C}$ e $15000 \mathrm{~g}$ por 32 minutos. $\mathrm{O}$ sobrenadante foi coletado e armazenado a $-70^{\circ} \mathrm{C}$ para análises posteriores. A concentração de proteína foi determinada espectrofotometricamente a $595 \mathrm{~nm}$ como descrito por Bradford (1976).

A atividade da CAT foi determinada segundo o método de Kraus et al. (1995), com algumas modificações. $\mathrm{O}$ ensaio enzimático foi feito em um $\mathrm{mL}$ de uma solução $100 \mathrm{mM}$ de fosfato de potássio, $\mathrm{pH}$ 7,5 e 0,25 \% (v/v) de $\mathrm{H}_{2} \mathrm{O}_{2}$ comercial (30 \%). O início da reação é obtido com a adição de $25 \mu \mathrm{L}$ de extrato vegetal em cubeta de quartzo diretamente no espectrofotômetro, ajustado para $240 \mathrm{~nm}$ (pico de absorção do $\mathrm{H}_{2} \mathrm{O}_{2}$ ). A reação foi monitorada por 1 minuto com leituras em intervalos de 1 segundo. A atividade da enzima foi determinada seguindo-se a queda na absorbância a $240 \mathrm{~nm}$. Os resultados foram expressos em $\mu \mathrm{mol} \mathrm{H}_{2} \mathrm{O}_{2} /$ minuto/mg de proteína.

A atividade de GR foi determinada como descrito por Smith et al. (1988), com algumas modificações. A atividade enzimática foi determinada colorimetricamente a $30^{\circ} \mathrm{C}$ em um $\mathrm{mL}$ de uma solução $100 \mathrm{mM}$ de fosfato de potássio, $\mathrm{pH} 7,5,1 \mathrm{mM}$ de DTNB, 1 mM de GSSG e 0,1 mM de NADPH. A reação foi iniciada com a adição de $50 \mu \mathrm{l}$ de extrato vegetal. O tempo de amostragem foi de 1 minuto com dosagens feitas em intervalos de 1 segundo. A taxa de redução da glutationa oxidada foi seguida por monitoramento das alterações na absorbância a $412 \mathrm{~nm}$. Os valores de atividade foram expressos em $\mu \mathrm{mol}$ de GSSG reduzido/minuto/mg de proteína.

Os extratos vegetais tiveram suas proteínas separadas por eletroforese em gel não desnaturante de poliacrilamida com $9 \%$ de acrilamida. A solução tampão de eletrodo foi $250 \mathrm{mM}$ de TRIS, $\mathrm{pH}$ 8,3, e 1,92 $\mathrm{M}$ de glicina. Foi utilizada corrente constante de 15mA por gel. Para a eletroforese da GR foi aplicado $23 \mu \mathrm{g}$ de proteina por canaleta e a revelação foi feita de acordo com o método citado em Lee \& Lee (2000). Após a eletroforese o gel é lavado com água e incubado no escuro por 30 minutos à $30{ }^{\circ} \mathrm{C}$ em $50 \mathrm{~mL}$ de uma solução $250 \mathrm{mM}$ de TRIS, pH 7,5, 3,4 mM de glutationa oxidada e 0,5 mM de NADPH, contendo $10 \mathrm{mg}$ de MTT e $10 \mathrm{mg}$ de DPIP. 
Para a confirmar que as bandas eram de GR, foram feitos géis controle sem GSSG. Para a eletroforese da CAT foi utilizado $50 \mu \mathrm{g}$ de proteína por canaleta e como padrão foi aplicado uma unidade de catalase de fígado bovino. A revelação foi feita de acordo com o método citado em Azevedo et al. (1998). Após a eletroforese e 3 lavagens de 15 minutos com água, o gel é incubado por 10 minutos em solução 0,003 \% (p/v) de $\mathrm{H}_{2} \mathrm{O}_{2}$, à temperatura ambiente e com agitação suave e constante. $\mathrm{O}$ gel é então lavado rapidamente em água e colocado por 10 minutos em uma solução $1 \%$ (p/v) de $\mathrm{FeCl}_{3}$ e $1 \%(\mathrm{p} / \mathrm{v})$ de $\mathrm{K}_{2} \mathrm{Fe}\left(\mathrm{CN}_{6}\right)$ também sob agitação. Em seguida, a solução é retirada e o gel lavado com água. Para a eletroforese da SOD foi utilizada $23 \mu \mathrm{g}$ de proteína por canaleta e como padrão foram aplicadas 2 unidades de SOD de fígado bovino. A revelação foi feita de acordo com o método citado em Azevedo et al. (1998). Após a eletroforese, o gel é lavado rapidamente em água destilada e incubado no escuro em uma mistura com $30 \mathrm{~mL}$ de solução A e $70 \mathrm{~mL}$ de solução $\mathrm{B}$, preparadas com menos de uma hora de antecedência e mantidas o escuro. A solução A é 0,005 \% (p/v) de riboflavina e a solução B é $100 \mathrm{mM}$ de fosfato de potássio, $\mathrm{pH} 7,8,0,02 \%(\mathrm{p} / \mathrm{v})$ de NBT, $0,02 \%(\mathrm{p} / \mathrm{v})$ de EDTA e 0,003 \% (v/v) de TEMED. O gel permanece 30 minutos na solução de incubação, sob agitação e no escuro. Após esse período a solução é retirada, o gel é imerso em água destilada e levado à luz. Nestas condições ocorre a fotorredução do NBT no gel, propiciando a formação de uma coloração púrpura e as bandas correspondentes à atividade de SOD permanecem translúcidas devido a inibição da fotorredução realizada pela enzima, promovendo uma revelação negativa, assim como para CAT.

Entre novembro e dezembro de 2002 foram cultivadas novamente plantas da linha 2 nas mesmas condições deste experimento 1 e foram coletadas sub-amostras das raízes em cada nível de $\mathrm{N}$ para análise de eletroforese em gel não desnaturante para a GR. Para estas sub-amostras as raízes foram separadas entre as mais velhas e as mais novas. As mais velhas foram consideradas as desenvolvidas abaixo da terceira fileira de raízes de cima para baixo no caule e as mais novas foram as desenvolvidas na terceira e acima desta com exceção da fileira mais alta que foi colhida como mais uma amostra de raízes recém desenvolvidas apenas no nível alto de N. As sub-amostras 
novas e velhas foram coletadas da mesma forma como no experimento 1, ou seja, coletando-se a parte distal das raízes com cerca de $15 \mathrm{~cm}$ de comprimento. No experimento 1 as amostras continham raízes de ambos os tipos consideradas novas e velhas. $\mathrm{Na}$ sub-amostra de raízes recém desenvolvidas, que mediam entre 3 e 5 centímetros de comprimento, o corte para a coleta foi feito a 1 centímetro do caule. As raízes mais velhas podem ser consideradas em sua maioria como finas de acordo com o critério de McCully (1999), pois apresentavam diâmetro menor que 0,8 mm. As raízes mais novas são considerada grossas, e as recém desenvolvidas também podem ser assim consideradas.

\subsubsection{Experimento 2}

Plantas de cevada (Hordeum vulgare var. Maris Mink) foram cultivadas em hidroponia em areia em potes de $1 \mathrm{~L}$, com 4 plantas por vaso. Foram usadas soluções de $0,25,0,5,1,10$ e $20 \mathrm{mM}$ de $\mathrm{N}$ na forma de nitrato de amônio com a mesma composição para os demais nutrientes das soluções utilizadas no experimento 1. A solução foi renovada a cada 4 dias com a adição de 1 L de solução. A água foi suprida com o mesmo esquema utilizado no experimento 1. A casa de vegetação utilizada é localizada no Field Station da Lancaster University, Inglaterra e as médias das temperaturas mínima e máxima foram 12 e $31{ }^{\circ} \mathrm{C}$, respectivamente. As sementes foram colocadas para germinar em papel toalha 5 dias antes do plantio que ocorreu no dia 4 de julho de 2002. Foram conduzidos cinco blocos e aos 27 dias após o plantio coletouse raízes de um deles para a análise de isoformas das enzimas CAT, GR e SOD seguindo os protocolos do experimento 1, com a diferença de que nesta análise da GR utilizou-se um padrão de GR de S. cerevisiae, aplicando-se 0,0025 unidade por canaleta. As amostras utilizadas nestas análises de eletroforese foram concentradas com filtros de centrífuga VIVASPIN (Sartorius Ltd. Inglaterra), principalmente as provenientes dos tratamentos com menores níveis de nitrogênio. As quantidades de proteína aplicadas nos géis foram 29, 16, e $190 \mu \mathrm{g}$ por canaleta, respectivamente, para GR, SOD e CAT. Para a revelação da CAT usou-se uma modificação para aumentar a intensidade das bandas que foi o repouso do gel por 10 minutos, após a retirada da 
solução de peróxido de hidrogênio e antes da lavagem que precede a adição da solução reveladora.

\subsection{Experimento em sala de crescimento}

Plantas de Arabidopsis thaliana (ecótipo Columbia) foram cultivadas em hidroponia em areia em potes de $20 \mathrm{~mL}$ com 20 plantas por pote. A sala de crescimento teve a temperatura mantida em $25{ }^{\circ} \mathrm{C}$ e foi fornecida iluminação artificial, com lâmpadas fluorescentes, para que, no nível das folhas existisse uma irradiância, na faixa fotossinteticamente ativa, de cerca de $90 \mu \mathrm{mol}$ de fótons $\mathrm{m}^{-2} \mathrm{~s}^{-1}$, com 14 horas de fotoperíodo. Foram usadas as mesmas 5 soluções do experimento 2 de casa de vegetação, renovadas semanalmente com adição de $20 \mathrm{~mL}$ de solução. Diariamente foi colocada água no prato de apoio de cada vaso para manter a umidade da areia por capilaridade. O plantio das sementes foi feito no dia 15 de agosto de 2002. Foram cultivados 10 potes de cada nível de $\mathrm{N}$ e aos 26 dias após o plantio coletou-se as raízes de todos os potes, para compor uma única amostra de cada nível de $\mathrm{N}$, com as quais foram efetuadas as mesmas análises do experimento 2 de casa de vegetação. As amostras utilizadas nestas análises de eletroforese foram concentradas com filtros de centrífuga VIVASPIN (Sartorius Ltd. Inglaterra), principalmente as provenientes dos tratamentos com menores níveis de nitrogênio. As quantidades de proteína aplicadas nos géis foram 64, 9, e $64 \mu \mathrm{g}$ por canaleta, respectivamente, para GR, SOD e CAT. 


\section{RESULTADOS}

\subsection{Experime ntos de campo}

\subsubsection{Comparação entre as linhas avaliadas nos experimentos 1 e 2}

No experimento 1 houve efeito das doses de $\mathrm{N}$ apenas nas variáveis teor de clorofila, teor de $\mathrm{N}$ nos grãos, $\mathrm{N}$ total e eficiência na utilização do $\mathrm{N}$. O efeito dos genótipos, por outro lado, foi significativo para todas as variáveis exceto a prolificidade, enquanto que a interação genótipos $x$ doses de $N\left(\begin{array}{lllll}G & x & N\end{array}\right)$ foi significativa para produtividade de grãos e teor de clorofila (Tabela 1). O efeito do $\mathrm{N}$, na produtividade de grãos, foi significativo apenas nas linhas 2 e 13. A linha 2 respondeu positivamente, enquanto a linha 13 apresentou redução na produtividade no

maior nível de $\mathrm{N}$. No nível baixo de $\mathrm{N}$, a maior produtividade de grãos (após os controles) foi obtida pelas linhas 6,10 e 13 (Tabela 2). Para o teor de clorofila somente a linha 3 não respondeu ao $\mathrm{N}$ aplicado e as linhas 2 e 4 apresentaram respectivamente os valores maior e menor, no nível alto de $\mathrm{N}$ (Tabela 2).

No experimento 2 foram obtidos efeitos significativos das doses de $\mathrm{N}$ para todas as variáveis, exceto a massa de cem grãos, e efeitos significativos dos genótipos para todas as variáveis. Interação $\mathrm{G} \times \mathrm{N}$ significativa foi detectada para produtividade de grãos, massa de cem grãos, prolificidade, sincronia no florescimento, teor de $\mathrm{N}$ nos grãos e $\mathrm{N}$ total (Tabela 1).

A produtividade de grãos do experimento 2 foi menor do que a do experimento 1, com uma redução de cerca de $50 \%$ para as plantas controle. Todos os genótipos, exceto as linhas 4 e 6, responderam significativamente à maior dose de $\mathrm{N}$. As maiores produtividades de grãos, após os controles, foram obtidas pelas linhas 6 e 10 no nível baixo de N (Tabela 3). No nível baixo de N, a população Sintético Elite NT apresentou 
maior produtividade de grãos do que a variedade BR 106 (Tabela 3). No experimento 2, a linha 2 foi a única que apresentou massa de cem grãos no nível baixo de $\mathrm{N}$ maior que no nível alto (Tabela 3). A prolificidade foi elevada significativamente pela maior dose de $\mathrm{N}$ em todas as linhas testadas no experimento 2, exceto nas linhas 6 e 10. Valores de prolificidade próximos de um, no nível baixo de $\mathrm{N}$, foram obtidos pelas linhas 6 e 10 e pelos dois materiais controle, Sintético Elite NT e BR 106 (Tabela 3).

A dose alta de $\mathrm{N}$, no experimento 2, causou aumento significativo na sincronia no florescimento nas linhas 3 e 5 . Aumento este que se caracteriza por uma menor quantidade de dias entre os florescimentos masculino e feminino. Elevada sincronia no florescimento foi detectada, sob baixo $\mathrm{N}$, nas linhas 4, 6, e 10 e ms materiais controle. A linha 6 apresentou protoginia no nível alto de $N$, no qual a linha 2 teve uma incomum falta de sincronia, que não foi afetada pelas doses de $\mathrm{N}$ (Tabela 3). A linha 10 foi a única do experimento 2 sem efeito significante das doses de $\mathrm{N}$ no teor de $\mathrm{N}$ dos grãos, enquanto que, para o total de $\mathrm{N}$ as linhas 2, 3 e 5 foram afetadas, exibindo menor valor no nível baixo de $\mathrm{N}$ (Tabela 3).

As correlações indicaram que a prolificidade, a sincronia no florescimento e o teor de $\mathrm{N}$ nos grãos foram mais associados com a produtividade nas condições do experimento 2 do que nas do experimento 1 (Tabela 4 ). 
Tabela 1. Análise de variância: Probabilidades dos efeitos das doses de nitrogênio $(\mathrm{N})$, genótipos (G) e interação ( $\mathrm{N}$ x $\mathrm{G})$ nas variáveis analisadas nos dois experimentos de campo.

\begin{tabular}{|c|c|c|c|c|c|c|}
\hline \multirow[b]{2}{*}{ Variável } & \multicolumn{2}{|c|}{ Experimento } & \multirow{2}{*}{$\frac{1}{\mathrm{Nx} G}$} & \multicolumn{2}{|c|}{ Experimento } & \multirow{2}{*}{$\frac{2}{N \times G}$} \\
\hline & $\mathrm{N}$ & $\mathrm{G}$ & & $\mathrm{N}$ & $\mathrm{G}$ & \\
\hline Produtividade de grãos & NS & $* *$ & $*$ & $* *$ & $* *$ & $*$ \\
\hline Número de grãos $\mathrm{pl}^{-1}$ & NS & $* *$ & NS & $* *$ & $* *$ & NS \\
\hline Massa de cem grãos & $\mathrm{NS}$ & $* *$ & NS & NS & $* *$ & $*$ \\
\hline Prolificidade & NS & NS & NS & $* *$ & $* *$ & $*$ \\
\hline Índice de colheita & NS & $*$ & NS & $*$ & $* *$ & NS \\
\hline Sincronia no florescimento & NS & $* *$ & NS & $* *$ & $* *$ & $*$ \\
\hline Número de folhas verdes $\mathrm{pl}^{-1}$ & NS & $* *$ & NS & $* *$ & $* *$ & NS \\
\hline Teor de clorofila & $* *$ & $* *$ & $*$ & $* *$ & $* *$ & NS \\
\hline Teor de $\mathrm{N}$ nos grãos & $* *$ & $* *$ & NS & $* *$ & $* *$ & $* *$ \\
\hline Total de $\mathrm{N} \mathrm{pl}^{-1}$ & $* *$ & $* *$ & NS & $* *$ & $* *$ & $* *$ \\
\hline Eficiência na utilização do $\mathrm{N}$ & $* *$ & $* *$ & NS & $* *$ & $* *$ & NS \\
\hline
\end{tabular}

$*$,** - Significante aos níveis de 5 e $1 \%$, respectivamente.

NS - Não significativo. 
Tabela 2. Teste $\mathrm{F}$ para o efeito das doses de nitrogênio $(\mathrm{N})$ em cada linha $(2,3,4,5,6$, 10, 13 e 17) e controles BR 106 (BR) e Sintético Elite NT (SE), e médias, sob alto e baixo $\mathrm{N}$, de produtividade de grãos (PG) (g pl-1) e teor de clorofila (TC) (unidades SPAD), no experimento 1.

\begin{tabular}{|c|c|c|c|c|c|c|c|c|c|c|}
\hline Variável & 2 & 3 & 4 & 5 & 6 & 10 & 13 & 17 & $\mathrm{BR}$ & SE \\
\hline \multicolumn{11}{|l|}{ PG } \\
\hline F & $* *$ & NS & NS & NS & NS & NS & $* *$ & NS & NS & NS \\
\hline Alto $\mathrm{N}$ & $53,5 \mathrm{~b}$ & $27,5 \mathrm{c}$ & $27,0 \mathrm{c}$ & $27,4 \mathrm{c}$ & $54,8 \mathrm{~b}$ & $37,9 \mathrm{bc}$ & $34,7 \mathrm{bc}$ & $22,5 \mathrm{c}$ & $97,7 \mathrm{a}$ & $97,5 \mathrm{a}$ \\
\hline Baixo N & 31,1 bcde & $27,7 \mathrm{cde}$ & $19,1 \mathrm{de}$ & $12,4 \mathrm{e}$ & $52,5 \mathrm{~b}$ & $42,1 \mathrm{bcd}$ & $50,9 \mathrm{bc}$ & $15,6 \mathrm{e}$ & $99,5 \mathrm{a}$ & $97,5 \mathrm{a}$ \\
\hline \multicolumn{11}{|l|}{$\mathrm{TC}$} \\
\hline $\mathrm{F}$ & $* *$ & NS & $*$ & $* *$ & $*$ & $*$ & $*$ & $*$ & NS & NS \\
\hline Alto $\mathrm{N}$ & $59,8 \mathrm{a}$ & $49,5 \mathrm{~cd}$ & $40,8 \mathrm{e}$ & $51,2 \mathrm{~cd}$ & $57,3 \mathrm{ab}$ & $48,4 \mathrm{~d}$ & $50,4 \mathrm{~cd}$ & $50,8 \mathrm{~cd}$ & $53,7 \mathrm{bc}$ & $54,0 \mathrm{bc}$ \\
\hline Baixo N & $46,3 \mathrm{a}$ & $48,0 \mathrm{a}$ & $35,6 \mathrm{~b}$ & $44,6 \mathrm{ab}$ & $52,8 \mathrm{a}$ & $44,2 \mathrm{ab}$ & $45,7 \mathrm{a}$ & $45,4 \mathrm{a}$ & $49,6 \mathrm{a}$ & $50,2 \mathrm{a}$ \\
\hline
\end{tabular}

*, ** - Significante aos níveis de 5 e $1 \%$, respectivamente.

NS - Não significativo.

Valores seguidos da mesma letra, dentro da mesma linha, não diferem significativamente pelo teste de Tukey ao nível de $5 \%$ de probabilidade. 
Tabela 3. Teste $\mathrm{F}$ para o efeito das doses de nitrogênio $(\mathrm{N})$ em cada linha $(2,3,4,5,6$ e 10) e controles BR 106 (BR) e Sintético Elite NT (SE), e médias, sob alto e baixo $\mathrm{N}$, de produtividade de grãos, massa de cem grãos, prolificidade, sincronia do florescimento, teor de $\mathrm{N}$ nos grãos e $\mathrm{N}$ total no experimento 2.

\begin{tabular}{|c|c|c|c|c|c|c|c|c|}
\hline Variável & 2 & 3 & 4 & 5 & 6 & 10 & $\mathrm{BR}$ & SE \\
\hline \multicolumn{9}{|c|}{ Produtividade de grãos $\left(\mathrm{g} \mathrm{pl}^{-1}\right)$} \\
\hline $\mathrm{F}$ & $* *$ & $* *$ & NS & $*$ & NS & $*$ & $* *$ & $* *$ \\
\hline Alto $\mathrm{N}$ & $17,1 \mathrm{~cd}$ & $14,9 \mathrm{~d}$ & $15,9 \mathrm{~cd}$ & $15,4 d$ & $27,9 b$ & $25,8 b c$ & $51,6 \mathrm{a}$ & $54,3 \mathrm{a}$ \\
\hline Baixo N & $8,1 \mathrm{e}$ & $6,47 \mathrm{e}$ & 10,33de & $7,8 \mathrm{e}$ & $23,2 b c$ & $17,68 \mathrm{~cd}$ & $31,4 b$ & $43,3 \mathrm{a}$ \\
\hline \multicolumn{9}{|c|}{ Massa de cem grãos (g) } \\
\hline $\mathrm{F}$ & $* *$ & NS & NS & NS & NS & NS & $\mathrm{NS}$ & NS \\
\hline Alto $\mathrm{N}$ & $16,9 \mathrm{abc}$ & $13,2 \mathrm{~d}$ & $14,5 \mathrm{bcd}$ & $14,9 \mathrm{bcd}$ & $13,7 \mathrm{~cd}$ & $18,8 \mathrm{a}$ & $18,9 \mathrm{a}$ & $17,6 \mathrm{ab}$ \\
\hline Baixo $\mathrm{N}$ & $20,4 \mathrm{a}$ & $11,3 \mathrm{~d}$ & $13,6 \mathrm{~cd}$ & $14,9 \mathrm{bcd}$ & $13,2 \mathrm{~cd}$ & $16,8 \mathrm{abc}$ & $18,3 \mathrm{ab}$ & $16,6 \mathrm{bc}$ \\
\hline \multicolumn{9}{|c|}{ Prolificidade (espigas $\mathrm{pl}^{-1}$ ) } \\
\hline $\mathrm{F}$ & $* *$ & $* *$ & $*$ & $* *$ & NS & NS & $*$ & $*$ \\
\hline Alto $\mathrm{N}$ & $1,08 \mathrm{ab}$ & $1,02 \mathrm{ab}$ & 1,08ab & $0,95 b$ & $1,05 \mathrm{ab}$ & $1,05 \mathrm{ab}$ & $1,21 \mathrm{ab}$ & $1,23 \mathrm{a}$ \\
\hline Baixo N & $0,65 \mathrm{c}$ & $0,72 \mathrm{bc}$ & $0,88 \mathrm{abc}$ & $0,63 \mathrm{c}$ & $1,02 \mathrm{a}$ & $1,01 \mathrm{ab}$ & $0,97 \mathrm{ab}$ & $1,01 \mathrm{ab}$ \\
\hline \multicolumn{9}{|c|}{ Sincronia no florescimento (dias) } \\
\hline $\mathrm{F}$ & NS & $*$ & $\mathrm{NS}$ & $* *$ & NS & NS & $*$ & NS \\
\hline Alto $\mathrm{N}$ & $4,8 \mathrm{a}$ & $1,3 \mathrm{~cd}$ & $0,8 \mathrm{~cd}$ & $2,8 b$ & $-0,4 \mathrm{e}$ & $1,8 \mathrm{bc}$ & $0,5 \mathrm{de}$ & $0,3 \mathrm{e}$ \\
\hline Baixo N & $4,4 \mathrm{ab}$ & $2,7 \mathrm{bc}$ & $1,1 \mathrm{c}$ & $5,9 \mathrm{a}$ & $0,5 \mathrm{c}$ & $2,5 \mathrm{bc}$ & $2,1 \mathrm{bc}$ & $0,3 \mathrm{c}$ \\
\hline \multicolumn{9}{|c|}{ Teor de $\mathrm{N}$ nos grãos $\left(\mathrm{g} \mathrm{Kg}^{-1}\right)$} \\
\hline $\mathrm{F}$ & $*$ & $* *$ & $* *$ & $* *$ & $* *$ & NS & $* *$ & $* *$ \\
\hline Alto N & $17,5 \mathrm{~d}$ & $20,3 a$ & $20,0 \mathrm{ab}$ & $18,8 \mathrm{bc}$ & $17,3 \mathrm{~d}$ & $17,8 \mathrm{~d}$ & $17,2 \mathrm{~d}$ & $16,8 \mathrm{~d}$ \\
\hline Baixo & $16,2 \mathrm{bcd}$ & $18,7 \mathrm{a}$ & $18,4 \mathrm{a}$ & $16,7 \mathrm{abc}$ & $15,1 \mathrm{~cd}$ & $17,4 \mathrm{ab}$ & 14,2 de & $12,9 \mathrm{e}$ \\
\hline \multicolumn{9}{|l|}{$\mathrm{N}$ total $\left(\mathrm{g} \mathrm{pl}^{-1}\right)$} \\
\hline $\mathrm{F}$ & $* *$ & $*$ & NS & $*$ & NS & NS & $* *$ & $* *$ \\
\hline Alto N & $1,47 \mathrm{~b}$ & $0,98 b$ & $1,01 \mathrm{~b}$ & $0,99 \mathrm{~b}$ & $1,46 b$ & $1,15 b$ & $2,57 \mathrm{a}$ & $2,19 \mathrm{a}$ \\
\hline Baixo N & $1,04 \mathrm{abc}$ & $0,57 \mathrm{~d}$ & $0,75 \mathrm{bcd}$ & $0,66 \mathrm{~cd}$ & $1,14 \mathrm{ab}$ & $0,96 a b c d$ & $\mathrm{~d} 1,41 \mathrm{a}$ & $1,42 \mathrm{a}$ \\
\hline
\end{tabular}

*,** - Significante aos níveis de 5 e $1 \%$, respectivamente.

NS - Não significativo.

Valores seguidos da mesma letra, dentro da mesma linha, não diferem significativamente pelo teste de Tukey ao nível de $5 \%$ de probabilidade. 
Tabela 4. Correlações simples entre a produtividade de grãos e as demais variáveis nas linhas e controles dos dois experimentos de campo.

\begin{tabular}{|c|c|c|c|c|}
\hline \multirow{2}{*}{ Variável } & \multicolumn{2}{|l|}{ Experimento } & Experimento & \multirow{2}{*}{$\frac{2}{\mathrm{~N} \text { baixo }}$} \\
\hline & $\mathrm{N}$ alto & $\mathrm{N}$ baixo & $\mathrm{N}$ alto & \\
\hline Número de grãos $\mathrm{pl}^{-1}$ & $0,83^{* *}$ & $0,85^{* *}$ & $0,95^{* *}$ & $0,96^{* *}$ \\
\hline Massa de cem grãos & $0,69^{* *}$ & $0,66^{* *}$ & $0,51^{* *}$ & $0,24^{\mathrm{NS}}$ \\
\hline Prolificidade & $0,15^{\mathrm{NS}}$ & $0,35^{*}$ & $0,56^{* *}$ & $0,63^{* *}$ \\
\hline Índice de colheita & $0,40^{*}$ & $0,85^{* *}$ & $0,81^{* *}$ & $0,81^{* *}$ \\
\hline Sincronia no florescimento & $-0,17^{\mathrm{NS}}$ & $-0,19^{\mathrm{NS}}$ & $-0,47^{* *}$ & $-0,60^{* *}$ \\
\hline Número de folhas verdes $\mathrm{pl}^{-1}$ & $0,58^{* *}$ & $0,68^{* *}$ & $0,42^{* *}$ & $0,51^{* *}$ \\
\hline Teor de clorofila & $0,45^{* *}$ & $0,59^{* *}$ & $0,56^{* *}$ & $0,61^{* *}$ \\
\hline Teor de $\mathrm{N}$ nos grãos & $-0,29^{\mathrm{NS}}$ & $-0,20^{\mathrm{NS}}$ & $-0,62^{* *}$ & $-0,74^{* *}$ \\
\hline $\mathrm{N}$ total $\mathrm{pl}^{-1}$ & $0,80^{* *}$ & $0,87^{* *}$ & $0,88^{* *}$ & $0,77^{* *}$ \\
\hline Eficiência na utilização do $\mathrm{N}$ & $0,45^{* *}$ & $0,57^{* *}$ & $0,81^{* *}$ & $0,81^{* *}$ \\
\hline
\end{tabular}

*, ** - Significante aos níveis de 5 e $1 \%$, respectivamente.

NS - Não significativo.

\subsubsection{Análise dialélica}

As variáveis estudadas podem ser agrupadas de acordo com as significâncias dos efeitos das capacidades geral e específica de combinação (CGC e CEC) (Tabela 5). A produtividade de grãos e o teor de clorofila apresentaram efeitos significativos da CGC e da CEC nos dois níveis de $\mathrm{N}$ e também para a interação da CGC com os níveis de $\mathrm{N}$. A massa de cem grãos, a eficiência na utilização do $\mathrm{N}$ e o teor de $\mathrm{N}$ nos grãos apresentaram significância para os efeitos da CGC e da CEC em ambos os níveis de N. O número de grãos apresentou significância para os efeitos da $\mathrm{CEC}$ nos dois níveis de $\mathrm{N}$, da CGC no nível alto de $\mathrm{N}$ e para a interação da CGC com os níveis de N. O índice de colheita, a prolificidade e o $\mathrm{N}$ total apresentaram significância para os efeitos da CGC no nível alto de $\mathrm{N}$, da CEC nos dois níveis de $\mathrm{N}$ e da interação da CGC com os níveis de $\mathrm{N}$. A área da folha da espiga e o número de folhas verdes apresentaram significância para os efeitos da CGC nos dois níveis de $\mathrm{N}$ e da CEC no nível baixo de 
N. A sincronia no florescimento apresentou significância para o efeito da CGC no nível alto de $\mathrm{N}$ (Tabela 5).

A significância dos efeitos da CGC indica que pelo menos uma das linhas difere das demais quanto à quantidade de genes favoráveis com efeitos aditivos. A significância da CEC indica, por sua vez, que existe complementação entre as linhas nos loci com algum grau de dominância. A interação da CGC com os níveis de $\mathrm{N}$ indica que não há consistência entre os efeitos observados em cada nível, ou seja, por exemplo, uma linha apresentando maiores efeitos aditivos, em um nível, pode não apresentar a mesma superioridade no outro nível.

De maneira geral os efeitos aditivos foram mais importantes do que os não aditivos, mas observou-se um aumento da importância dos efeitos não aditivos no nível baixo de $\mathrm{N}$ para as variáveis produtividade de grãos, número de grãos, índice de colheita, área da folha da espiga, $\mathrm{N}$ total e sincronia no florescimento (Tabela 5).

Para as variáveis com interação significativa da CGC com os níveis de $\mathrm{N}$, os efeitos desta capacidade foram calculados separadamente para cada nível de $\mathrm{N}$ e observa-se que há trocas nas posições relativas das linhas (Tabela 6). Para os efeitos da CGC da produtividade de grãos e do teor de clorofila, a linha 2 foi a melhor no nível alto de N, mas foi a terceira melhor no nível baixo de N. Para o efeito da CGC do número de grãos a maior alteração ocorreu com a linha 6 , que teve o maior valor no nível alto, e o terceiro maior valor no nível baixo de $\mathrm{N}$ (Tabela 6). A linha 5 se destacou nos efeitos da CGC para produtividade de grãos, apresentando o segundo maior valor no nível alto e o maior valor no nível baixo de N. A linha 10 teve também certo destaque nos efeitos da CGC para produtividade de grãos, apresentando os terceiro e segundo maiores valores nos níveis alto e baixo de $\mathrm{N}$, respectivamente.

Para as variáveis com interação não significativa da CGC com os níveis de $\mathrm{N}$, os efeitos das CGC das linhas foram calculados na média dos dois níveis de $\mathrm{N}$ (Tabela 7). A linha 5 apresentou elevados valores dos efeitos da CGC para as variáveis massa de cem grãos, área da folha da espiga e $\mathrm{N}$ total. Para a prolificidade, entretanto, a linha 5 apresentou valor inferior. A linha 10 apresentou valores elevados dos efeitos da CGC para as variáveis massa de cem grãos, índice de colheita, número de folhas verdes, 
eficiência na utilização do $\mathrm{N}$ e prolificidade. A linha 2 apresentou valores elevados dos efeitos da CGC para as variáveis número de folhas verdes, eficiência na utilização do $\mathrm{N}$ e prolificidade, entretanto esta linha deve possuir inferior quantidade de genes com efeitos aditivos para a sincronia do florescimento, uma vez que o seu efeito da CGG para esta variável foi o maior, o que significa que os híbridos produzidos com a linha 2 apresentam grande intervalo entre os florescimentos masculino e feminino e, portanto, menor sincronia no florescimento. A linha 6, por outro lado, apresentou o valor de efeito da CGC que indica a maior sincronia no florescimento.

Os efeitos da CEC foram calculados na média dos níveis alto e baixo de $\mathrm{N}$, para todas as variáveis, em função da ausência de significância da interação desta capacidade com os referidos níveis. O efeito da CEC do híbrido 2x10 para as variáveis produtividade de grãos, eficiência na utilização do $\mathrm{N}$ e prolificidade foram elevadas (Tabela 8), e isto assume importância, considerando que as linhas que lhe deram origem apresentaram elevados valores dos efeitos da CGC para estas variáveis (Tabela 7).

Os efeitos da CEC (Tabela 8) do teor de $\mathrm{N}$ nos grãos apresentaram, na maioria dos híbridos, sinais opostos aos dos efeitos das demais variáveis e também, de maneira geral entre as variáveis, os materiais com maior divergência dos efeitos da CGC (Tabelas 6 e 7) apresentaram os maiores efeitos da CEC (Tabela 8), mas o oposto ocorreu com o teor de $\mathrm{N}$ nos grãos. Estes comportamentos indicam a expressão de uma possível heterose negativa na variável teor de $\mathrm{N}$ nos grãos.

As correlações simples indicam que a sincronia no florescimento foi mais associada com a produtividade dos grãos no nível baixo do que no nível alto de N. Por outro lado, a eficiência na utilização do $\mathrm{N}$ e o teor de $\mathrm{N}$ nos grãos foram mais associados com a produtividade de grãos no nível alto de N (Tabela 9).

As correlações residuais foram não significativas para prolificidade, índice de colheita e eficiência na utilização do $\mathrm{N}$, em ambos os níveis de $\mathrm{N}$, indicando que nestas variáveis a correlação fenotípica se aproxima da genética (Tabela 9).

As correlações residuais indicaram maior associação ambiental entre produtividade de grãos e sincronia no florescimento, número de folhas verdes e teor de 
clorofila no nível baixo de $\mathrm{N}$, enquanto que o teor de $\mathrm{N}$ nos grãos foi mais associado com a produtividade de grãos no nível alto de $\mathrm{N}$ (Tabela 9).

Tabela 5. Análise de variância: Probabilidades para os efeitos da capacidade geral de combinação e da capacidade específica de combinação nos níveis alto (NA) e baixo (NB) de nitrogênio e na interação destes níveis, para as variáveis produtividade de grãos (PG), massa de cem grãos (MCG), número de grãos (NG), índice de colheita (IC), número de folhas verdes (NFV), área da folha da espiga (AFE), eficiência na utilização do nitrogênio (EUtN), nitrogênio total (NT), teor de nitrogênio nos grãos (TNG), sincronia no florescimento (SF), teor de clorofila (TC) e prolificidade (PRO).

\begin{tabular}{lllllllll}
\hline & CGC & & & CEC & & \multicolumn{2}{c}{$2 \mathrm{Vg} /(2 \mathrm{Vg}+\mathrm{Ve})$} \\
Variável & NA & NB & NAxNB & NA & NB & NAxNB & NA & NB \\
\hline PG & $* * *$ & $*$ & $* * *$ & $* * *$ & $* * *$ & NS & 0,73 & 0,46 \\
MCG & $* * *$ & $* * *$ & NS & $* * *$ & $* * *$ & NS & 0,73 & 0,77 \\
NG & $* * *$ & NS & $* * *$ & $* * *$ & $* * *$ & NS & 0,85 & 0,20 \\
IC & $* *$ & NS & NS & $*$ & $*$ & NS & 0,74 & 0,48 \\
NFV & $* * *$ & $* * *$ & NS & NS & $*$ & NS & 0,88 & 0,84 \\
AFE & $* * *$ & $* *$ & NS & NS & $* * *$ & NS & 0,95 & 0,63 \\
EutN & $* *$ & $* * *$ & NS & $* * *$ & $*$ & NS & 0,68 & 0,80 \\
NT & $* *$ & NS & NS & $* * *$ & $* *$ & NS & 0,70 & 0,46 \\
TNG & $* * *$ & $* * *$ & NS & $* *$ & $* *$ & NS & 0,84 & 0,88 \\
SF & $* * *$ & NS & NS & NS & NS & NS & 0,94 & 0,68 \\
TC & $* * *$ & $* * *$ & $*$ & $* * *$ & $* *$ & NS & 0,88 & 0,78 \\
PRO & $* *$ & NS & NS & $* *$ & $*$ & NS & 0,65 & 0,54 \\
\hline
\end{tabular}

***,**,* - Significante aos níveis de $0,1,1$ e $5 \%$, respectivamente.

NS - Não significativo.

Vg - Variância devida à capacidade geral de combinação.

Ve - Variância devida à capacidade especifica de combinação. 
Tabela 6. Efeitos de capacidade geral de combinação nos níveis alto (NA) e baixo (NB) de nitrogênio, para as variáveis produtividade de grãos (PG), número de grãos (NG) e teor de clorofila (TC).

\begin{tabular}{|c|c|c|c|c|c|c|}
\hline \multirow[b]{2}{*}{ Linha } & \multicolumn{2}{|l|}{$\underline{\mathrm{PG}}$} & \multicolumn{2}{|l|}{$\underline{\mathrm{NG}}$} & \multicolumn{2}{|l|}{$\underline{\mathrm{TC}}$} \\
\hline & NA & NB & NA & NB & NA & NB \\
\hline 2 & 8,68 & 1,26 & 53,28 & 7,21 & 2,69 & 0,27 \\
\hline 3 & $-5,43$ & $-1,91$ & $-21,36$ & 1,85 & $-3,37$ & $-2,40$ \\
\hline 4 & $-7,13$ & $-2,27$ & $-52,54$ & $-11,98$ & $-3,36$ & $-1,93$ \\
\hline 5 & 3,54 & 3,90 & $-0,45$ & 3,45 & 2,62 & 2,69 \\
\hline 6 & $-1,61$ & $-2,89$ & 23,62 & $-0,44$ & 1,89 & 1,79 \\
\hline 10 & 1,95 & 1,90 & $-2,57$ & $-0,08$ & 0,13 & $-0,41$ \\
\hline
\end{tabular}

Tabela 7. Efeitos de capacidade geral de combinação na média dos níveis alto e baixo de nitrogênio, para as variáveis massa de cem grãos (MCG), índice de colheita (IC), número de folhas verdes (NFV), área da folha da espiga (AFE), eficiência na utilização do nitrogênio (EUtN), nitrogênio total (NT), teor de nitrogênio nos grãos (TNG), sincronia no florescimento (SF) e prolificidade (PRO).

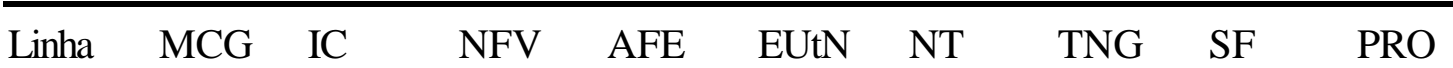

\begin{tabular}{llllllllll}
\hline 2 & 0,021 & 0,006 & 0,074 & 0,30 & 3,29 & 0,048 & $-0,84$ & 0,12 & 0,054 \\
3 & $-1,090$ & $-0,011$ & 0,058 & $-19,14$ & $-2,01$ & $-0,001$ & 0,81 & 0,02 & $-0,032$ \\
4 & 0,004 & $-0,018$ & $-0,010$ & $-29,95$ & $-2,67$ & $-0,039$ & 0,93 & 0,01 & $-0,015$ \\
5 & 1,760 & $-0,005$ & $-0,098$ & 27,34 & $-0,70$ & 0,053 & $-0,47$ & 0,01 & $-0,022$ \\
6 & $-1,619$ & 0,010 & $-0,206$ & 19,03 & 0,11 & $-0,050$ & $-0,59$ & $-0,23$ & 0,007 \\
10 & 0,923 & 0,018 & 0,182 & 2,41 & 1,98 & $-0,010$ & 0,17 & 0,07 & 0,008 \\
\hline
\end{tabular}


Tabela 8. Efeitos de capacidade específica de combinação na média dos níveis alto e baixo de nitrogênio, para as variáveis produtividade de grãos (PG), massa de cem grãos (MCG), número de grãos (NG), ńdice de colheita (IC), número de folhas verdes (NFV), área da folha da espiga (AFE), eficiência na utilização do nitrogênio (EUtN), nitrogênio total (NT), teor de nitrogênio nos grãos (TNG), teor de clorofila (TC) e prolificidade (PRO).

\begin{tabular}{lccccccccccc}
\hline Híbrido & PG & MCG NG & IC & NFV & AFE & EUtN & NT & TNG & TC & PRO \\
\hline 2X3 & 4,21 & 1,13 & 11,9 & 0,02 & 0,02 & 24,4 & 3,61 & 0,01 & $-0,68$ & 1,52 & 0,02 \\
2X4 & 6,82 & $-0,58$ & 51,7 & 0,02 & 0,15 & 24,8 & 3,10 & 0,03 & $-0,75$ & 1,54 & 0,10 \\
2X5 & $-4,17$ & $-0,94$ & $-14,6$ & $-0,02$ & $-0,10$ & $-22,0$ & $-2,99$ & $-0,02$ & 0,88 & $-0,37$ & $-0,06$ \\
2X6 & $-6,08$ & 0,03 & $-42,1$ & $-0,03$ & $-0,15$ & $-17,1$ & $-4,21$ & $-0,04$ & 0,64 & $-0,80$ & $-0,05$ \\
2X10 & $-0,78$ & 0,35 & $-6,9$ & 0,01 & 0,08 & $-10,0$ & 0,50 & 0,03 & $-0,09$ & $-1,88$ & $-0,01$ \\
3X4 & $-20,78$ & $-3,72$ & $-81,2$ & $-0,06$ & $-0,24$ & $-67,2$ & $-7,94$ & $-0,21$ & 1,47 & $-6,32$ & $-0,13$ \\
3X5 & 6,33 & 1,99 & 11,8 & 0,00 & 0,07 & 16,6 & $-0,33$ & 0,13 & $-0,07$ & 2,55 & 0,05 \\
3X6 & 7,76 & 1,17 & 32,3 & 0,03 & 0,16 & 16,1 & 2,79 & 0,08 & $-0,61$ & 1,01 & 0,04 \\
3X10 & 2,49 & $-0,57$ & 25,2 & 0,01 & $-0,01$ & 10,1 & 1,87 & $-0,01$ & $-0,10$ & 1,24 & 0,03 \\
4X5 & 5,60 & 1,44 & 19,8 & 0,03 & 0,14 & 10,5 & 3,65 & 0,03 & $-0,28$ & $-0,21$ & $-0,00$ \\
$4 X 6$ & 3,46 & 0,55 & 17,7 & 0,01 & $-0,03$ & 20,8 & 1,91 & 0,05 & $-0,29$ & 2,40 & 0,06 \\
4X10 & 4,91 & 2,31 & $-8,0$ & 0,01 & $-0,02$ & 11,1 & $-0,72$ & 0,10 & $-0,15$ & 2,59 & $-0,02$ \\
5X6 & $-3,13$ & $-1,07$ & $-7,3$ & 0,00 & $-0,02$ & $-6,9$ & 0,42 & $-0,05$ & $-0,30$ & $-1,31$ & $-0,01$ \\
5X10 & $-4,62$ & $-1,42$ & $-9,8$ & $-0,01$ & $-0,10$ & 1,8 & $-0,74$ & $-0,09$ & $-0,23$ & $-0,66$ & 0,03 \\
6X10 & $-2,00$ & $-0,68$ & $-0,5$ & $-0,01$ & 0,04 & $-12,9$ & $-0,91$ & $-0,03$ & 0,57 & $-1,29$ & $-0,03$ \\
\hline
\end{tabular}


Tabela 9. Correlações entre a produtividade de grãos e as demais variáveis nos 15 híbridos do Experimento 2.

\begin{tabular}{|c|c|c|c|c|}
\hline \multirow[t]{2}{*}{ Variável } & \multicolumn{2}{|c|}{ Correlação simples } & \multicolumn{2}{|c|}{ Correlação residual } \\
\hline & $\mathrm{N}$ alto & $\mathrm{N}$ baixo & $\mathrm{N}$ alto & $\mathrm{N}$ baixo \\
\hline Número de grãos $\mathrm{pl}^{-1}$ & $0,84^{* *}$ & $0,89^{* *}$ & $0,79^{* *}$ & $0,90^{* *}$ \\
\hline Massa de cem grãos & $0,60^{* *}$ & $0,60^{* *}$ & $0,38^{* *}$ & $0,49^{* *}$ \\
\hline Prolificidade & $0,41 * *$ & $0,48^{* *}$ & $0,10^{\mathrm{NS}}$ & $0,15^{\mathrm{NS}}$ \\
\hline Índice de colheita & $0,43^{* *}$ & $0,36^{* *}$ & $0,17^{\mathrm{NS}}$ & $0,13^{\mathrm{NS}}$ \\
\hline Sincronia no florescimento & $0,00^{\mathrm{NS}}$ & $-0,37^{* *}$ & $0,11^{\mathrm{NS}}$ & $-0,38^{* *}$ \\
\hline Número de folhas verdes $\mathrm{pl}^{-1}$ & $0,45^{* *}$ & $0,51^{* *}$ & $0,21^{\mathrm{NS}}$ & $0,50^{* *}$ \\
\hline Teor de clorofila & $0,71^{* *}$ & $0,70^{* *}$ & $0,17^{\mathrm{NS}}$ & $0,70^{* *}$ \\
\hline Teor de $\mathrm{N}$ nos grãos & $-0,49^{* *}$ & $-0,19^{\mathrm{NS}}$ & $-0,23^{*}$ & $0,18^{\mathrm{NS}}$ \\
\hline $\mathrm{N}$ total $\mathrm{pl}^{-1}$ & $0,60^{* *}$ & $0,76^{* *}$ & $0,31^{* *}$ & $0,26^{*}$ \\
\hline Eficiência na utilização do N & $0,53^{* *}$ & $0,27^{* *}$ & $0,21^{\mathrm{NS}}$ & $-0,12^{\mathrm{NS}}$ \\
\hline Área da folha da espiga & $0,52^{* *}$ & $0,61^{* *}$ & $0,41^{* *}$ & $0,34^{* *}$ \\
\hline
\end{tabular}

*,** - Significante aos níveis de 5 e $1 \%$, respectivamente.

NS - Não significativo.

\subsection{Experimentos em casa de vegetação}

\subsubsection{Experimento 1}

Existiu efeito das doses de $\mathrm{N}$ em todas as variáveis analisadas e efeito dos genótipos em todas as variáveis exceto na fotossíntese. Interação entre genótipos e doses de $\mathrm{N}$ foi detectada para as massas da parte aérea e da raiz, teor e total de $\mathrm{N}$ na parte aérea, teor de proteínas solúveis na raiz e atividades das enzimas catalase e glutationa redutase. Houve heterose na média dos dois níveis de $\mathrm{N}$ para massas da parte aérea e da raiz, porcentagem de folhas senescentes, teor de proteína solúvel na raiz, teor e total de $\mathrm{N}$ na parte aérea e razão $F v / F m$. Para a razão $F v / F m$ e para a fotossíntese existiu efeito significativo das doses de $\mathrm{N}$ e os valores médios foram de 10,8 e 18,1 $\mu \mathrm{mol} \mathrm{CO}_{2} \mathrm{~m}^{-2} \mathrm{~s}^{-1}$ nos níveis baixo e alto, respectivamente. Estes valores de fotossíntese foram similares aos encontrados por Lu \& Zhang (2000). Heteroses 
médias (diferença entre a média dos híbridos e a das linhas) para massas da parte aérea e da raiz e teor de $\mathrm{N}$ também ocorreram isoladamente nos dois níveis de $\mathrm{N}$, enquanto que a heterose média para $\mathrm{N}$ total e para teor de proteína solúvel na raiz ocorreu no nível alto, mas não no nível baixo de $\mathrm{N}$ (Tabela 10). Estas heteroses médias explicam parte da interação genótipos x doses de $\mathrm{N}$ para massas da parte aérea e da raiz, teor de proteína solúvel na raiz e teor e total de $\mathrm{N}$ na parte aérea. Para a atividade da catalase parte desta interação foi devida ao efeito significativo das doses de $\mathrm{N}$ nas linhas 2 e 4 e no híbrido 46, mas não nos demais genótipos. Para a atividade da glutationa redutase parte desta interação foi devida ao efeito menos pronunciado das doses de $\mathrm{N}$ na linha 4 e no híbrido 24 do que nos demais genótipos (Tabela 11).

A linha 2 apresentou maior teor de clorofila que a linha 4, na média dos níveis de N (Tabela 12).

A disponibilidade de $\mathrm{N}$ afetou o padrão de isoformas da GR, que apresentou pelo menos uma banda extra, menos eletropositiva, na condição de maior disponibilidade de $\mathrm{N}$ (Figura 5). Estes resultados concordam com a maior atividade quantificada no espectrofotômetro do nível alto de $\mathrm{N}$, embora a quantificação tenha indicado uma superioridade em relação à que pode ser visualizada no gel. A análise das sub-amostras demonstrou que esta banda extra foi exclusiva das raízes novas (grossas) do tratamento do nível alto de N. Para as raízes recém desenvolvidas o perfil foi completamente diferente das demais amostras pois apresentou uma isoforma menos eletropositiva que as das demais amostras e não apresentou bandas correspondentes àquelas das outras amostras (Figura 6).

Para a CAT a eletroforese confirmou os resultados da quantificação em espectrofotômetro mostrando principalmente que a baixa atividade das amostras dos tratamentos de baixo $\mathrm{N}$, é devida à menor atividade de uma banda também presente no nível alto de $\mathrm{N}$. A não significância do contraste entre os níveis de $\mathrm{N}$ para as atividades das linhas 2 e 6 (Tabela 11) parece ter ocorrido pela maior intensidade de uma banda menos eletropositiva no nível baixo de N (Figura 5), que poderia estar compensando a menor atividade da banda mais eletropositiva. Para o híbrido 46, por outro lado, a não 
significância deste contraste parece ter ocorrido pela relativamente menor atividade no nível alto de $\mathrm{N}$.

As amostras dos níveis alto e baixo de $\mathrm{N}$ apresentaram similaridade para a SOD nas isoformas presentes e também na intensidade das mesmas. A linha 2, entretanto, apresentou intensidade maior no nível baixo de N.

Tabela 10. Análise de variância: Probabilidades para os efeitos de nitrogênio (N), genótipo $(\mathrm{G})$, interação $(\mathrm{N} \times \mathrm{G})$, heterose na média dos níveis de $\mathrm{N}$ (HvsL), heterose no nível baixo de $\mathrm{N}$ (HvsL-B) e heterose no nível alto de N (HvsL-NA).

\begin{tabular}{lllllll}
\hline Variável & $\mathrm{N}$ & $\mathrm{G}$ & $\mathrm{NxG}$ & $\mathrm{HvsL}$ & HvsL-A HvsL-B \\
\hline Massa da parte aérea seca & $* *$ & $* *$ & $* *$ & $* *$ & $* *$ & $* *$ \\
Massa da raiz seca & $* *$ & $* *$ & $* *$ & $* *$ & $* *$ & $* *$ \\
Teor de clorofila & $* *$ & $* *$ & $\mathrm{NS}$ & $\mathrm{NS}$ & - & - \\
Folhas senescentes & $*$ & $*$ & $\mathrm{NS}$ & $* *$ & - & - \\
Teor de N & $* *$ & $* *$ & $*$ & $* *$ & $* *$ & $* *$ \\
N total & $* *$ & $* *$ & $* *$ & $* *$ & $* *$ & $\mathrm{NS}$ \\
Fotossíntese & $* *$ & $\mathrm{NS}$ & $\mathrm{NS}$ & $\mathrm{NS}$ & - & - \\
Fv/Fm & $* *$ & $* *$ & $\mathrm{NS}$ & $*$ & - & - \\
Proteína radiculares & $* *$ & $* *$ & $* *$ & $* *$ & $* *$ & $\mathrm{NS}$ \\
Catalase & $* *$ & $*$ & $*$ & $\mathrm{NS}$ & $\mathrm{NS}$ & $\mathrm{NS}$ \\
Glutationa redutase & $* *$ & $*$ & $*$ & $\mathrm{NS}$ & $\mathrm{NS}$ & $\mathrm{NS}$ \\
\hline
\end{tabular}

*, ** - Significante aos níveis de 5 e $1 \%$, respectivamente.

NS - Não significante. 
Tabela 11. Teste F para o efeito do nitrogênio em cada linha (2, 4 e 6$)$ e híbrido $(24,26$ e 46) de milho e médias das variáveis nos níveis alto e baixo de nitrogênio $(\mathrm{N})$.

\begin{tabular}{|c|c|c|c|c|c|c|c|}
\hline Variável & & 2 & 4 & 6 & 24 & 26 & 46 \\
\hline $\begin{array}{l}\text { Massa da parte } \\
\text { aérea seca }\left(\mathrm{g} \mathrm{pl}^{-1}\right)\end{array}$ & $\begin{array}{l}\mathrm{F} \\
\mathrm{N} \text { alto } \\
\mathrm{N} \text { baixo }\end{array}$ & $\begin{array}{l}* * \\
6,0 \mathrm{~b} \\
1,5 \mathrm{ab}\end{array}$ & $\begin{array}{l}* * \\
5,7 \mathrm{~b} \\
1,4 \mathrm{ab}\end{array}$ & $\begin{array}{l}* * \\
6,2 \mathrm{~b} \\
1,3 \mathrm{~b}\end{array}$ & $\begin{array}{l}* * \\
10,0 \mathrm{a} \\
1,9 \mathrm{a}\end{array}$ & $\begin{array}{l}* * \\
7,6 \mathrm{~b} \\
1,7 \mathrm{ab}\end{array}$ & $\begin{array}{l}* * \\
10,2 \mathrm{a} \\
1,7 \mathrm{ab}\end{array}$ \\
\hline $\begin{array}{l}\text { Massa da raiz } \\
\text { seca }\left(\mathrm{g} \mathrm{pl}^{-1}\right)\end{array}$ & $\begin{array}{l}\mathrm{F} \\
\mathrm{N} \text { alto } \\
\mathrm{N} \text { baixo }\end{array}$ & $\begin{array}{l}* * \\
1,7 \mathrm{~d} \\
0,5 \mathrm{~b}\end{array}$ & $\begin{array}{l}* * \\
2,7 \mathrm{~cd} \\
0,8 \mathrm{ab}\end{array}$ & $\begin{array}{l}* * \\
3,0 \mathrm{bc} \\
0,6 \mathrm{~b}\end{array}$ & $\begin{array}{l}* * \\
4,0 \mathrm{ab} \\
0,9 \mathrm{a}\end{array}$ & $\begin{array}{l}* * \\
3,2 \mathrm{bc} \\
0,8 \mathrm{ab}\end{array}$ & $\begin{array}{l}* * \\
5,0 \mathrm{a} \\
1,0 \mathrm{a}\end{array}$ \\
\hline $\begin{array}{l}\text { Teor de } \mathrm{N} \text { na } \\
\text { parte aérea }\left(\mathrm{g} \mathrm{Kg}^{-1}\right)\end{array}$ & $\begin{array}{l}\mathrm{F} \\
\mathrm{N} \text { alto } \\
\mathrm{N} \text { baixo }\end{array}$ & $\begin{array}{l}* * \\
14,9 \mathrm{abc} \\
9,3 \mathrm{ab}\end{array}$ & $\begin{array}{l}* * \\
17,5 \mathrm{a} \\
10,5 \mathrm{a}\end{array}$ & $\begin{array}{l}* * \\
16,2 \mathrm{ab} \\
9,1 \mathrm{~b}\end{array}$ & $\begin{array}{l}* * \\
13,4 \mathrm{bc} \\
8,8 \mathrm{~b}\end{array}$ & $\begin{array}{l}* * \\
13,7 \mathrm{bc} \\
8,2 \mathrm{~b}\end{array}$ & $\begin{array}{l}* * \\
12,6 \mathrm{c} \\
8,8 \mathrm{~b}\end{array}$ \\
\hline $\begin{array}{l}\text { Total de } \mathrm{N} \text { na } \\
\text { parte aérea }(\mathrm{g})\end{array}$ & $\begin{array}{l}\mathrm{F} \\
\mathrm{N} \text { alto } \\
\mathrm{N} \text { baixo }\end{array}$ & $\begin{array}{l}* * \\
0,09 \mathrm{~b} \\
0,01 \mathrm{a}\end{array}$ & $\begin{array}{l}* * \\
0,10 \mathrm{~b} \\
0,02 \mathrm{a}\end{array}$ & $\begin{array}{l}* * \\
0,10 \mathrm{~b} \\
0,01 \mathrm{a}\end{array}$ & $\begin{array}{l}* * \\
0,13 \mathrm{a} \\
0,02 \mathrm{a}\end{array}$ & $\begin{array}{l}* * \\
0,10 \mathrm{~b} \\
0,01 \mathrm{a}\end{array}$ & $\begin{array}{l}* * \\
0,13 \mathrm{a} \\
0,02 \mathrm{a}\end{array}$ \\
\hline $\begin{array}{l}\text { Proteína solúvel na } \\
\left.\text { raiz (mg g raiz fresca }{ }^{-1}\right)\end{array}$ & $\begin{array}{l}\mathrm{F} \\
\mathrm{N} \text { alto } \\
\mathrm{N} \text { baixo }\end{array}$ & $\begin{array}{l}* * \\
1,46 \mathrm{a} \\
0,40 \mathrm{a}\end{array}$ & $\begin{array}{l}* * \\
1,22 \mathrm{ab} \\
0,58 \mathrm{a}\end{array}$ & $\begin{array}{l}* * \\
1,03 \mathrm{ab} \\
0,48 \mathrm{a}\end{array}$ & $\begin{array}{l}\mathrm{NS} \\
0,72 \mathrm{~b} \\
0,43 \mathrm{a}\end{array}$ & $\begin{array}{l}* * \\
0,85 \mathrm{ab} \\
0,43 \mathrm{a}\end{array}$ & $\begin{array}{l}\text { NS } \\
0,62 b \\
0,37 a\end{array}$ \\
\hline $\begin{array}{l}\text { Atividade da catalase } \\
\left(\mu \mathrm{mol} \mathrm{H}_{2} \mathrm{O}_{2} \mathrm{~min}^{-1} \mathrm{mg}^{-1}\right)\end{array}$ & $\begin{array}{l}\mathrm{F} \\
\mathrm{N} \text { alto } \\
\mathrm{N} \text { baixo }\end{array}$ & $\begin{array}{l}\mathrm{NS} \\
33,3 \mathrm{a} \\
23,2 \mathrm{ab}\end{array}$ & $\begin{array}{l}* \\
28,0 \mathrm{a} \\
9,7 \mathrm{~b}\end{array}$ & $\begin{array}{l}\mathrm{NS} \\
25,3 \mathrm{a} \\
33,7 \mathrm{a}\end{array}$ & $\begin{array}{l}* * \\
46,7 \mathrm{a} \\
22,2 \mathrm{ab}\end{array}$ & $\begin{array}{l}* \\
42,4 \mathrm{a} \\
26,3 \mathrm{ab}\end{array}$ & $\begin{array}{l}\text { NS } \\
23,7 \mathrm{a} \\
19,9 \mathrm{ab}\end{array}$ \\
\hline $\begin{array}{l}\text { Atividade da glutationa } \\
\text { redutase } \\
\left(\mu \mathrm{mol} \mathrm{GSSG} \mathrm{min}^{-1} \mathrm{mg}^{-1}\right)\end{array}$ & $\begin{array}{l}\mathrm{F} \\
\mathrm{N} \text { alto } \\
\mathrm{N} \text { baixo }\end{array}$ & $\begin{array}{l}* * \\
1543 \mathrm{a} \\
238 \mathrm{a}\end{array}$ & $\begin{array}{l}* * \\
903 \mathrm{a} \\
208 \mathrm{a}\end{array}$ & $\begin{array}{l}* * \\
1457 \mathrm{a} \\
141 \mathrm{a}\end{array}$ & $\begin{array}{l}* * \\
799 \mathrm{a} \\
205 \mathrm{a}\end{array}$ & $\begin{array}{l}* * \\
1430 \mathrm{a} \\
98 \mathrm{a}\end{array}$ & $\begin{array}{l}* * \\
1512 \mathrm{a} \\
210 \mathrm{a}\end{array}$ \\
\hline
\end{tabular}

*,** - Significante aos níveis 5 e $1 \%$, respectivamente

NS - Não significante

Médias seguidas de mesma letra, dentro de cada linha, não diferem pelo teste Tukey ao nível de $5 \%$ de probabilidade. 
Tabela 12. Valores das variáveis na média dos níveis alto e baixo de nitrogênio para as linhas (2, 4, e 6) e híbridos (24, 26 e 46).

\begin{tabular}{lllllll}
\hline Variável & 2 & 4 & 6 & 24 & 26 & 46 \\
\hline Clorofila (unidades SPAD) & $36,7 \mathrm{a}$ & $31,9 \mathrm{~b}$ & $34,6 \mathrm{ab}$ & $35,0 \mathrm{a}$ & $35,7 \mathrm{a}$ & $34,7 \mathrm{a}$ \\
Razão $F v / F m$ & $0,76 \mathrm{ab}$ & $0,74 \mathrm{~b}$ & $0,77 \mathrm{a}$ & $0,77 \mathrm{a}$ & $0,78 \mathrm{a}$ & $0,76 \mathrm{ab}$ \\
Folhas senescentes (\%) & $47,3 \mathrm{ab}$ & $52,9 \mathrm{a}$ & $50,5 \mathrm{ab}$ & $41,9 \mathrm{~b}$ & $44,7 \mathrm{ab}$ & $46,0 \mathrm{ab}$ \\
\hline
\end{tabular}

Médias seguidas de mesma letra, dentro de cada linha, não diferem pelo teste Tukey ao nível de $5 \%$ de probabilidade. 


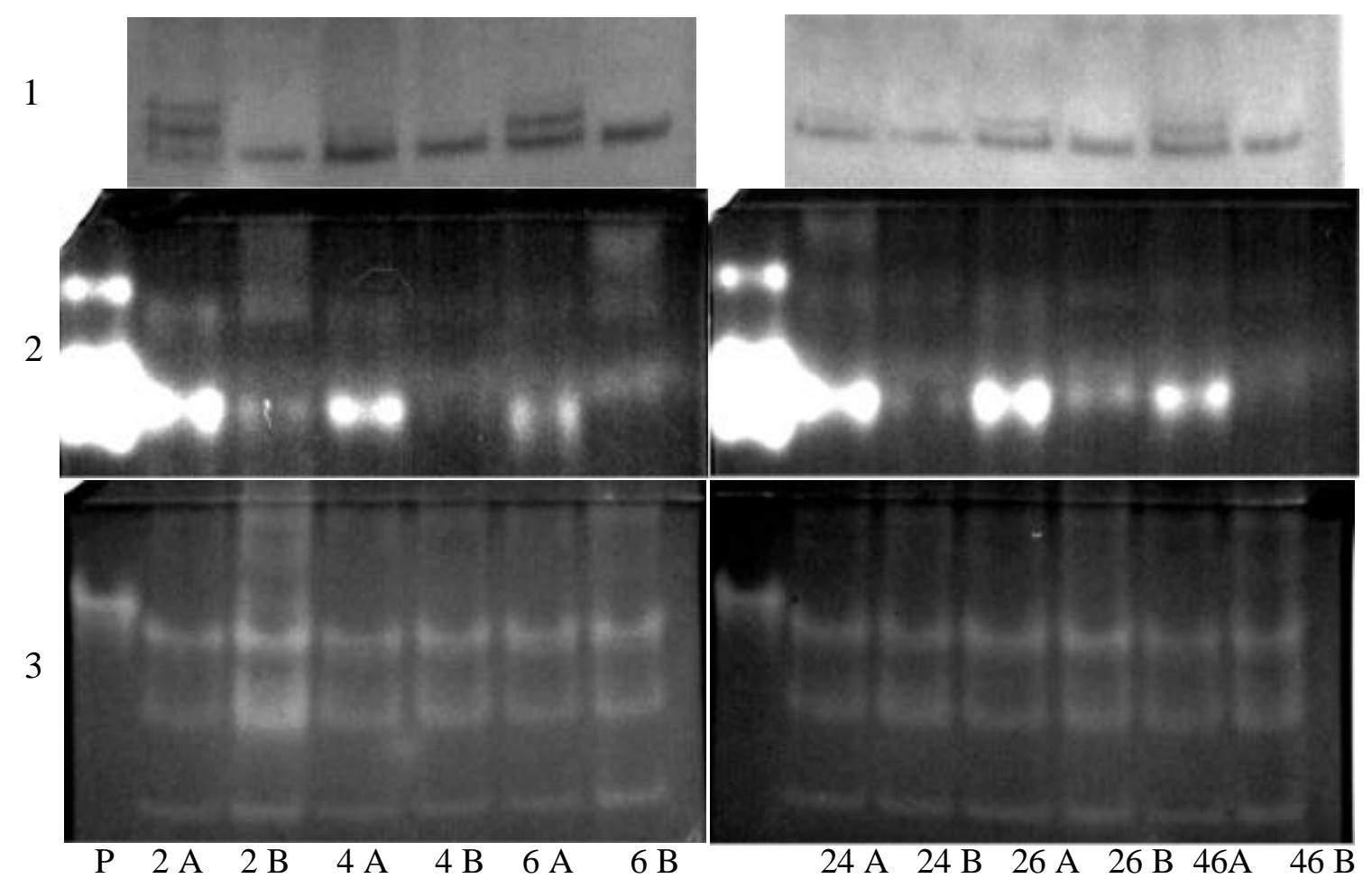

Figura 5 - Perfil isoenzimático de GR (1), CAT (2) e SOD (3) de raízes das linhas (2, 4 e 6) e seus híbridos $(24,26$ e 46) cultivados em alto (A) e baixo (B) suprimento de N. Nos géis de CAT e SOD foi utilizado padrão (P).

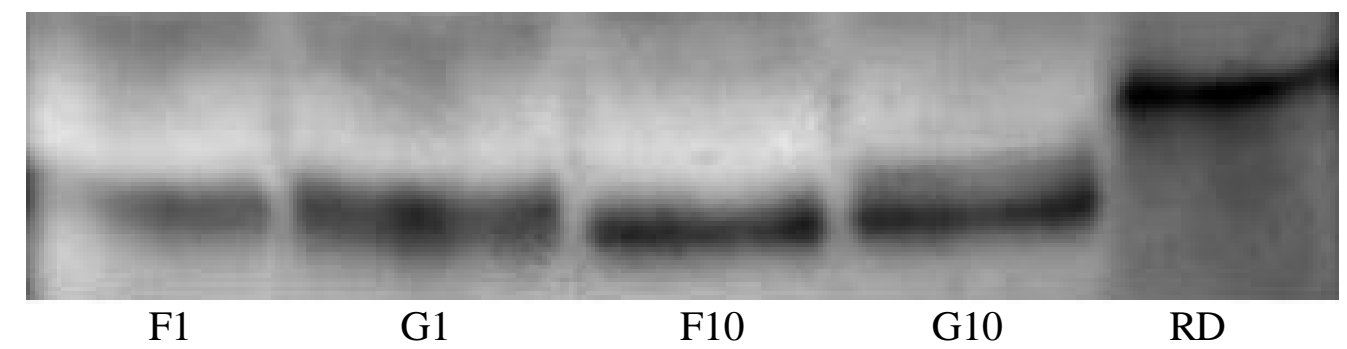

Figura 6 - Perfil isoenzimático de GR nas raízes das sub-amostras finas (F) e grossas (G) de plantas da linha 2 cultivadas com 1 e $10 \mathrm{mM}$ de N, e também das raízes recém desenvolvidas $(\mathrm{R})$ das plantas do nível de $10 \mathrm{mM}$ de $\mathrm{N}$. 


\subsubsection{Experimento 2}

Existiu efeito das doses de $\mathrm{N}$ no crescimento das plantas de cevada, como se observa na Figura 7. As raízes das plantas do nível mais baixo de $\mathrm{N}(0,25 \mathrm{mM})$ apresentaram atividade muito fraca de GR comparada com os demais níveis. As amostras dos dois mais altos níveis de N (20 e $10 \mathrm{mM}$ ) apresentaram bandas mais intensas que as correspondentes nos níveis 1 e 0,5 Mm. As amostras dos níveis 1 e 0,5 $\mathrm{mM}$ apresentaram uma banda a mais que as amostras dos níveis mais altos, sendo que esta foi mais eletropositiva que as demais (Figura 8).

Para a CAT observou-se uma tendência de bandas mais intensas no nível de 20 mM em comparação com os demais, com exceção do menor nível que também apresentou bandas com elevada intensidade. Observou-se também, que não houve correspondência entre as bandas presentes em todos os tratamentos (Figura 8).

Para a SOD, pouca variação entre os tratamentos no que se refere à presença $\mathrm{e}$ intensidade de bandas foi observada. Para o grupo de bandas mais eletropositivas existiram aparentes mudanças graduais, pois as bandas relativamente mais eletropositivas apresentaram menor intensidade do nível baixo para o alto de $\mathrm{N}$ e o oposto parece ocorrer com as bandas relativamente menos eletropositivas deste grupo. A banda menos eletropositiva também apresentou decréscimo de intensidade do menor para o maior nível de N (Figura 8). 


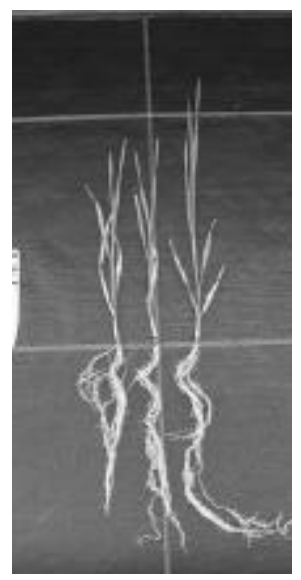

0,25

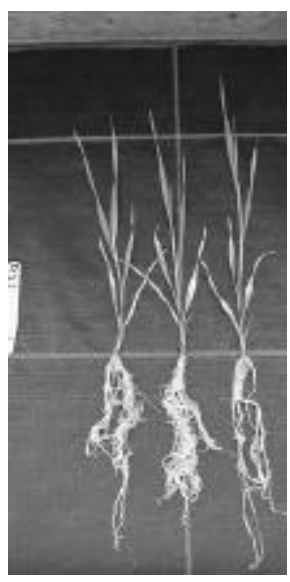

0,5

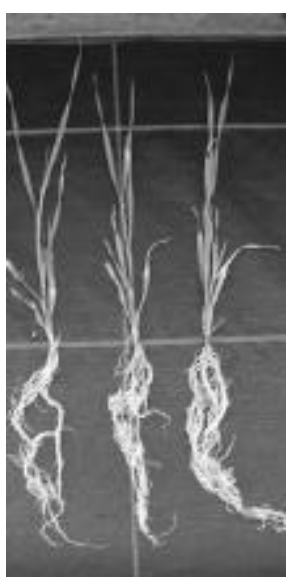

1

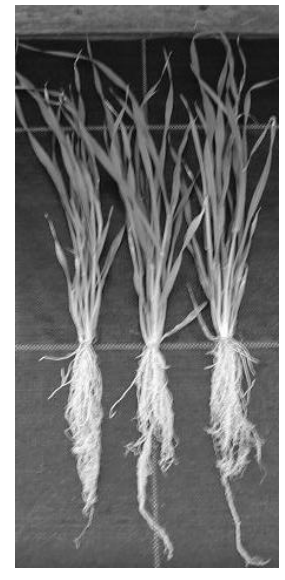

10

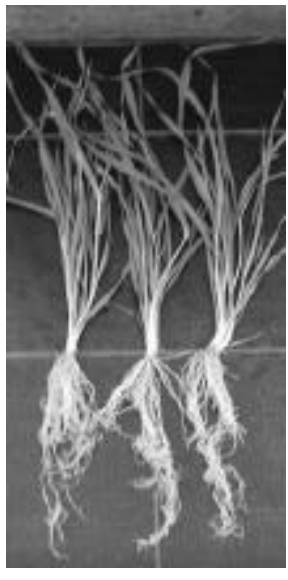

20

Figura 7 - Plantas de cevada cultivadas em cinco níveis de $\mathrm{N}(0,25,0,5,1,10$ e 20 $\mathrm{mM}$ ), no dia da colheita do experimento. 


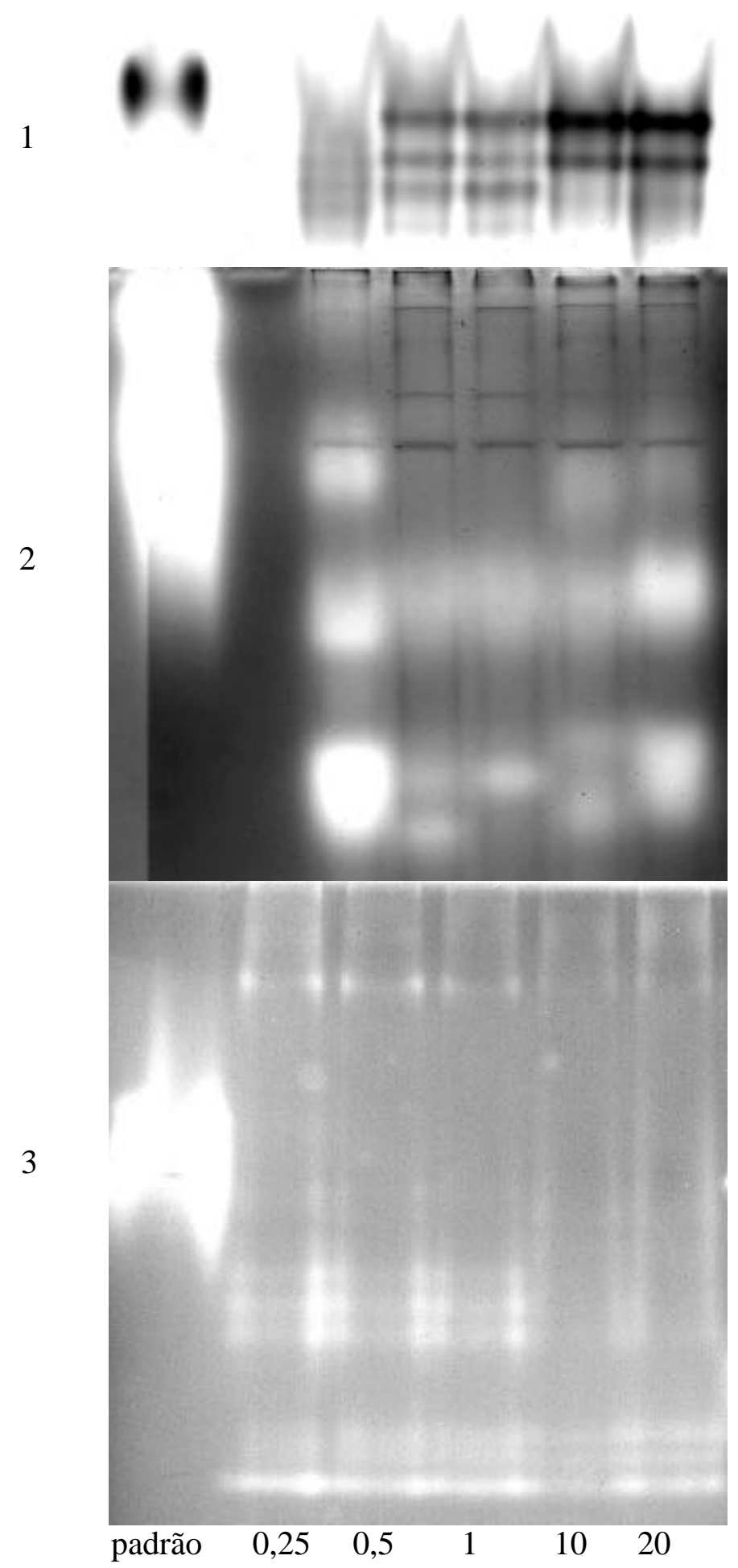

Figura 8 - Perfil isoenzimático de GR (1), CAT (2) e SOD (3) de raízes de cevada cultivada em cinco níveis de $\mathrm{N}(0,25,0,5,1,10$ e $20 \mathrm{mM})$. 


\subsection{Experimento em sala de crescimento}

As plantas de Arabidopsis thaliana apresentaram efeito dos níveis de N, como se observa na Figura 9, e as raízes das plantas dos dois níveis mais altos de $\mathrm{N}$ apresentaram uma banda de GR, menos eletropositiva, e outra, mais eletropositiva, a mais do que os demais tratamentos (Figura 10).

Para a CAT as amostras apresentaram presença de isoformas semelhantes quanto ao padrão de migração e observou-se uma maior intensidade nas bandas dos tratamentos de maior nível de N (Figura 10).

Para a SOD as amostras apresentaram isoformas semelhantes quanto ao padrão de migração com pequena variação nas intensidades. A isoforma menos eletropositiva apresentou decréscimo gradativo do menor para o maior nível de N (Figura 10).

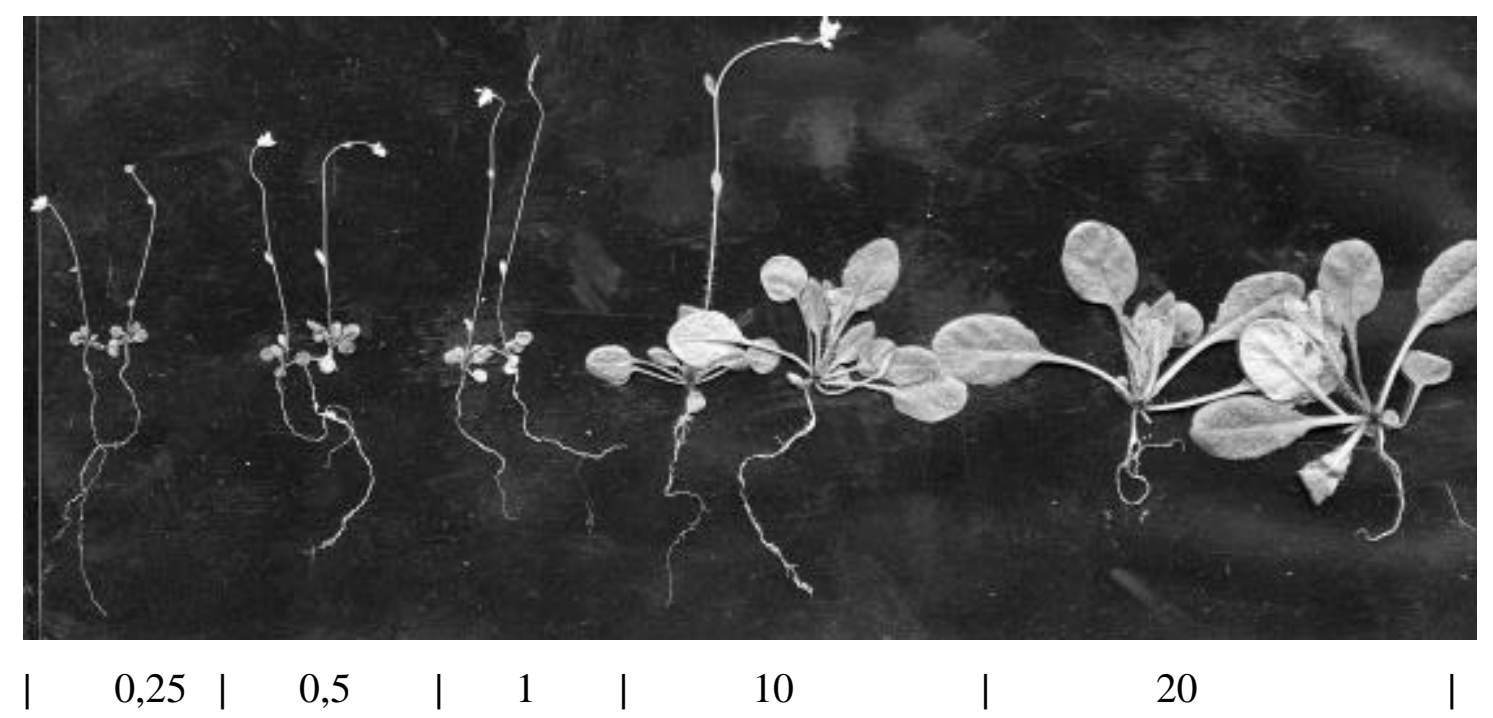

Figura 9 - Plantas de Arabidopsis thaliana cultivadas em cinco níveis de $\mathrm{N}$ (0,25, 0,5, 1, 10 e $20 \mathrm{mM})$, no dia da colheita do experimento. 


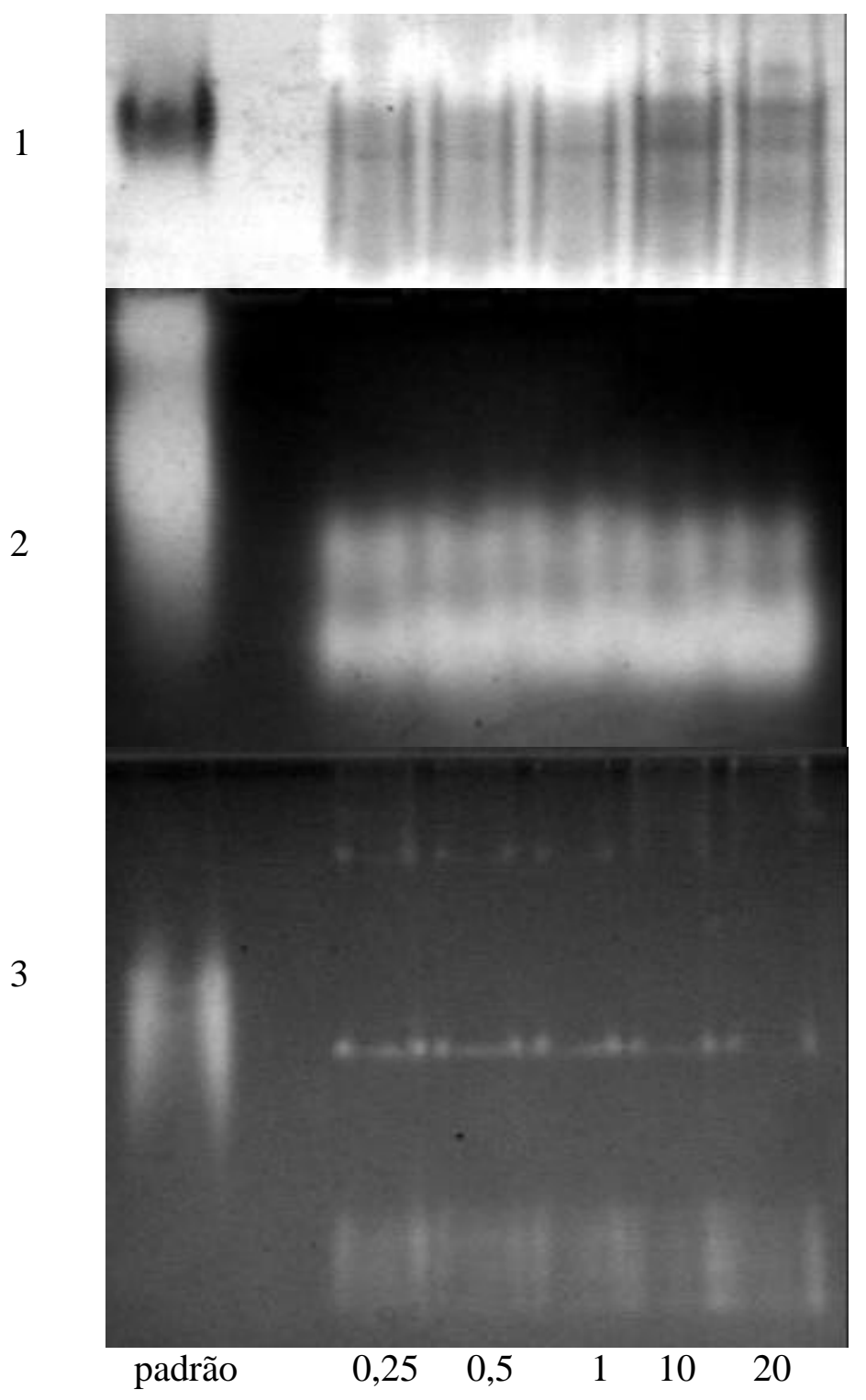

Figura 10 - Perfil isoenzimático de GR (1), CAT (2) e SOD (3) de raízes de Arabidopsis thaliana cultivada em cinco níveis de N $(0,25,0,5,1,10$ e $20 \mathrm{mM})$. 


\section{DISCUSSÃO}

\subsection{Experimentos de campo}

\subsubsection{Comparação entre as linhas avaliadas nos experimentos 1 e 2}

$\mathrm{O}$ efeito do $\mathrm{N}$ foi maior no experimento 2, afetando mais variáveis do que no experimento 1 (Tabela 1). No experimento 2 os dois materiais controles e 4 linhas apresentaram resposta positiva ao $\mathrm{N}$ aplicado, na produtividade de grãos, enquanto que apenas uma linha apresentou semelhante comportamento no experimento 1. Isto indica que a deficiência de $\mathrm{N}$ foi mais severa no experimento 2. A pequena influência das doses de $\mathrm{N}$, no experimento 1 , também pode indicar que a aplicação da maior dose de $\mathrm{N}$ representou um excesso de $\mathrm{N}$. Provavelmente a maior fertilidade do solo do experimento 1 contribuiu para este aparente excesso de $\mathrm{N}$.

Os resultados da produtividade de grãos indicam que a linha 6 foi tolerante à deficiência de $\mathrm{N}$, pois ela apresentou o maior valor (após os controles) no nível baixo de $\mathrm{N}$ do experimento 2 e não apresentou sensibilidade ao efeito do $\mathrm{N}$ adicional em ambos os experimentos (Tabelas 2 e 3). A linha 2 foi responsiva ao N, apresentando aumento na produtividade de grãos em resposta ao $\mathrm{N}$ adicional em ambos os experimentos (Tabelas 2 e 3). A linha 13 foi sensível à alta disponibilidade de $\mathrm{N}$, pois apresentou decréscimo da produtividade de grãos no nível alto de $\mathrm{N}$ do experimento 1 (Tabela 2). Decréscimo na produtividade de grãos, acarretado por alta disponibilidade de N, também foi observado por Pinter et al. (1995). A variação na resposta da produtividade de grãos em resposta ao $\mathrm{N}$ também foi observada por Balko \& Russel (1980a), que descreveram linhas de milho sem resposta, com resposta linear e com resposta quadrática ao suprimento de N. Murulli \& Paulsen (1981) também demonstraram respostas genótipo específicas ao suprimento de $\mathrm{N}$, e Agrama et al. 
(1999) identificaram regiões cromossômicas específicas para as produtividades de grãos com e sem deficiência de N. Rizzi et al. (1993) também mostraram que as limitações do metabolismo do $\mathrm{N}$ podem ser diferentes em solos com alta e baixa disponibilidade de $\mathrm{N}$.

Para o teor de clorofila as linhas 2 e 4 apresentaram, respectivamente valores alto e baixo, enquanto a linha 3 foi a única que não apresentou efeito das doses de $\mathrm{N}$ no experimento 1 (Tabela 2). Bänziger \& Lafitte (1997) demonstraram que o teor de clorofila representa uma variável útil no melhoramento para EUN, pois a seleção realizada com um índice baseado nesta variável e também nas variáveis sincronia no florescimento, prolificidade, número de folhas verdes abaixo da espiga e produtividade de grãos, permitiu progresso genético superior para produtividade, em solos pobres em $\mathrm{N}$, do que a seleção baseada apenas na produtividade.

As correlações indicaram que as associações do teor de clorofila com a produtividade de grãos foram semelhantes nas diferentes condições dos dois experimentos.

Para a prolificidade as linhas 2, 3, 4 e 5 foram sensíveis à deficiência de $\mathrm{N}$ do experimento 2 (Tabela 3). Efeito significante dos genótipos foi obtido apenas no experimento 2, o que está de acordo com os resultados de Moll et al. (1987), que demonstraram que a variação genética para a prolificidade pode ser mais facilmente detectada em ambientes com deficiência de $\mathrm{N}$, do que em alta disponibilidade deste nutriente.

$\mathrm{O}$ efeito do $\mathrm{N}$ na massa de cem grãos só foi significativo na linha 2, quando testada no experimento 2 (Tabela 3). A falta de efeito, na maioria dos materiais, pode provavelmente ser explicada pela alocação de fotoassimilados em um número reduzido de grãos, resultantes da deficiência de N (Kiniry et al., 1990). Aparentemente a linha 2 apresenta uma exacerbação deste efeito compensatório, uma vez que ela foi a única na qual a deficiência de $\mathrm{N}$ causou aumento na massa de cem grãos (Tabela 3).

Os resultados para a sincronia no florescimento indicam que as linhas 6 e 2 possuem respectivamente elevada e reduzida sincronia, e que a deficiência de $\mathrm{N}$ reduziu a sincronia das linhas 3 e 5 (Tabela 3). A seca também pode reduzir a 
sincronia no florescimento e Sari-Gorla et al. (1999) mostraram que existem diferentes regiões cromossômicas controlando a sincronia do florescimento nos ambientes com e sem seca. A população Sintético Elite NT, que foi usada como controle nos experimentos, também apresentou elevada sincronia no florescimento (Tabela 3), o que era esperado, uma vez que esta população sofreu seleção para elevada sincronia em ambiente pobre em N. (Santos et al., 1998). Esta variável vem sendo considerada como importante critério de seleção, no melhoramento da produtividade em solos pobres em N (Lafitte \& Edmeades, 1994a; Santos et al., 1998), embora Bänziger et al. (1997) tenham encontrado maior contribuição da prolificidade e do atraso na senescência do que para a sincronia do florescimento.

As correlações mostraram que a sincronia no florescimento e a prolificidade foram mais associadas com a produtividade de grãos, nas condições de menor disponibilidade de $\mathrm{N}$, indicando a relação destas variáveis com a tolerância à deficiência de N (Tabela 4).

A linha 10 foi a única do experimento 2 na qual a deficiência de $\mathrm{N}$ não reduziu o teor de $\mathrm{N}$ nos grãos (Tabela 3). Esta variável foi negativamente correlacionada com a produtividade de grãos, nas condições de menor disponibilidade de $\mathrm{N}$ (Tabela 4). Reduzido teor de $\mathrm{N}$ nos grãos tem sido associado com produtividade sob deficiência de N (Ma \& Dwyer, 1998), embora seja possível encontrar informação contraditória sobre este assunto, por exemplo, nos trabalhos de Lafitte et al. (1997) e Machado (1997) que indicaram o elevado teor de $\mathrm{N}$ nos grãos como importante para a produtividade em solos pobres em N. O trabalho de Lafitte \& Edmeades (1994c) demonstra a falta de consistência da associação do teor de $\mathrm{N}$ nos grãos com a produtividade em solo pobre em $\mathrm{N}$, pois em uma estação a correlação entre estas variáveis foi de 0,98 , enquanto que na subsequente ela foi invertida para $-0,97$.

A deficiência de $\mathrm{N}$, no experimento 2, reduziu o total de $\mathrm{N}$ nas linhas 2,3 e 5 (Tabela 3). É provável que estas linhas apresentem sistema radicular com limitação na capacidade de explorar maior volume de solo. Esta possibilidade é sugerida pelo trabalho de Gastal \& Lemaire (2002), o qual indica que, quando a disponibilidade de N é limitada, a absorção de $\mathrm{N}$ é largamente dependente da distribuição das raízes, uma 
vez que normalmente os transportadores de $\mathrm{N}$ da planta são capazes de extrair $\mathrm{N}$ do solo mesmo em concentrações muito baixas. As linhas 3 e 5 parecem ter maior limitação na absorção de $\mathrm{N}$, pois apresentaram valores inferiores de $\mathrm{N}$ total no nível baixo de N. A linha 2, por outro lado, apresentou efeito das doses de $\mathrm{N}$ no $\mathrm{N}$ total principalmente pelo elevado valor no nível alto de $\mathrm{N}$.

Outras variáveis avaliadas são consideradas importantes para a eficiência no uso do N, mas, para as linhas estudadas, não foram observadas respostas contrastantes ao N. Bertin \& Gallais (2000) obtiveram variância significante na interação genótipo x $\mathrm{N}$ para o número de grãos por planta, a qual foi altamente correlacionada com a interação para a produtividade de grãos. Rizzi et al. (1993) observaram que o índice de colheita foi mais associado à produtividade de grãos no nível baixo do que no nível alto de $\mathrm{N}$.

A EUN em milho é claramente uma variável complexa (Hirel et al., 2001) e as distintas respostas das linhas usadas neste estudo, ilustram parte desta complexidade. Por exemplo, a deficiência de $\mathrm{N}$ reduziu a prolificidade e a sincronia no florescimento na linha 5, enquanto que na linha 2 só a prolificidade foi afetada (Tabela 3).

A interação genótipo $\mathrm{x} \mathrm{N}$ observada para produtividade de grãos, teor de clorofila, massa de cem grãos, prolificidade, sincronia no florescimento, teor de $\mathrm{N}$ nos grãos e $\mathrm{N}$ total indicam que estas variáveis possuem diferentes controles genéticos em cada nível de disponibilidade de N. Estes resultados também indicam que as respostas destas variáveis ao $\mathrm{N}$ podem ser independentes, uma vez que estas respostas não foram consistentes entre as linhas avaliadas.

\subsubsection{Análise dialélica}

A magnitude dos efeitos aditivos foi maior do que a dos não aditivos, na maioria das variáveis analisadas. Rizzi et al. (1993) também encontraram relação semelhante na genética de variáveis relacionadas ao metabolismo do N. Entretanto a deficiência de $\mathrm{N}$ aumentou a importância dos efeitos não aditivos nas variáveis produtividade de grãos, número de grãos, índice de colheita, área da folha da espiga, $\mathrm{N}$ total e sincronia no florescimento (Tabela 5). Heterose maior em ambiente com 
estresse ambiental também foi observado por Giauffret et al. (1997), para taxas de crescimento da biomassa e da área foliar em milho. Neste trabalho de Giauffret et al. (1997), o estresse ambiental foi devido provavelmente à menor temperatura do plantio precoce, no qual as taxas de crescimentos da biomassa e da área foliar foram inferiores às dos plantios na época normal.

Para a produtividade de grãos não existiu associação entre o comportamento das linhas em cada nível de $\mathrm{N}$ com os seus efeitos de CGC. A linha linha 6 apresentou a maior produtividade na condição de maior deficiência de $\mathrm{N}$, mas apresentou o menor efeito de CGC nesta condição. A linha 10 no nível baixo de $\mathrm{N}$ superou a linha 5, mas o oposto ocorreu com os efeitos de CGC no nível baixo de N. A linha 6 e a linha 2 apresentaram produtividades equivalentes na condição de maior disponibilidade de $\mathrm{N}$, mas as linhas 2 e 6 apresentaram, respectivamente, o maior e o quarto maior efeitos de CGC no nível alto de N. Estes resultados estão de acordo com os de Lafitte \& Edmeades (1995) quanto ao fato das posições relativas das produtividades das linhas não serem associadas com as posições relativas dos efeitos de CGC em solos com e sem deficiência de N. A falta de associação entre as produtividades das linhas e de seus híbridos também foi relatada por Krone \& Lambert (1995) e Balko \& Russel (1980b).

As produtividades das linhas não foram associados com os seus efeitos de CGC para a produtividade, entretanto existiu a sugestão da capacidade das linhas responderem aos incrementos de $\mathrm{N}$ estar relacionada aos seus efeitos de CGC para a produtividade. As linhas com maior resposta ao $\mathrm{N}$ foram as de maior efeito de CGC. A linha 2 foi a mais responsiva e foi a que teve o maior efeito de CGC no nível alto e a de terceiro maior efeito no nível baixo. A linha 5 respondeu ao $\mathrm{N}$ no experimento 2 e foi a que teve a maior resposta ao $\mathrm{N}$, embora não significativa, depois da linha 2 no experimento 1, e esta linha 5 teve o segundo maior efeito de CGC no nível alto de $\mathrm{N}$ e o maior efeito no nível baixo de N. As linhas 4 e 6 foram as menos sensíveis aos níveis de $\mathrm{N}$ nos dois experimentos e foram as que tiveram os menores efeitos de CGC no nível baixo de $\mathrm{N}$ e apresentaram valores enquadrados entre os três piores no nível alto. Krone \& Lambert (1995b) mostraram que a seleção de linhas em ambiente com 
elevado nível de $\mathrm{N}$ pode gerar híbridos superiores e capazes de responder melhor aos incrementos de N. Estes autores realizaram cruzamentos teste das linhas, selecionadas em diferentes níveis de $\mathrm{N}$, justamente com uma linha conhecida por ser responsiva ao N. As linhas desenvolvidas em ambientes com alta disponibilidade de $\mathrm{N}$ apresentaram capacidade de responder ao $\mathrm{N}$ para a produtividade, mas as linhas desenvolvidas em nível inferior de $\mathrm{N}$ não apresentaram esta resposta (Krone \& Lambert, 1995a). Os trabalhos de Krone \& Lambert (1995a e 1995b) são um exemplo da possível importância da responsividade das linhas para formar híbridos superiores, pelo menos para o nível alto de $\mathrm{N}$. Não há referência à produtividade sob baixo $\mathrm{N}$ no trabalho de Krone \& Lambert (1995b), entretanto existe a possibilidade de híbridos superiores terem bom desempenho em condições de limitação de N. Esta possibilidade pode ser deduzida do fato dos híbridos modernos dos EUA superarem os antigos, em solos com ou sem deficiência de $\mathrm{N}$ (Duvick, 1984). Existem também trabalhos que mostram materiais comerciais, que não foram selecionados especificamente para tolerância à deficiência de $\mathrm{N}$, apresentando maior produtividade, em solos pobres em $\mathrm{N}$, do que variedades locais que atravessaram várias gerações em solos pobres em N (Machado et al., 1998; Lafitte et al., 1997). A associação entre produtividades em solos com e sem deficiência de $\mathrm{N}$ também poder ser encontrada nos trabalhos de melhoramento específicos para tolerância à deficiência de N (Lafitte \& Edmeades, 1994a; Lafitte \& Edmeades, 1995), pois estes trabalhos evidenciaram a possibilidade de elevada produtividade em solo pobre em $\mathrm{N}$, sem grande prejuízo da produtividade em solos sem esta deficiência.

O trabalho de Balko \& Russel (1980a) também fornece outro indício da importância da capacidade das linhas responderem ao N para a formação de híbridos superiores, uma vez que eles escolheram trabalhar com 10 linhas reconhecidamente importantes para a formação de híbridos comerciais e demonstraram que 9 se comportaram como responsivas. Supondo que esta amostra tenha alguma representatividade das linhas usadas em híbridos comerciais, é razoável supor que em um par de linhas progenitoras de um híbrido simples comercial, pelo menos uma pode ser responsiva ao N. Duvick (1992) também fornece uma importante informação sobre 
a relevância da responsividade das linhas ao N, relatando que a década de 60 marca a introdução dos híbridos simples e também o início de intensa seleção de linhas e híbridos para a tolerância a altos níveis de adubação nitrogenada. $\mathrm{O}$ uso do híbrido simples provocou uma substituição das linhas usadas até então, por famílias de linhas inteiramente novas e gerou híbridos que superam os antigos tanto nos ambientes de alta como nos de baixa produtividade (Duvick, 1992). Esta superação, apresentada pelos novos híbridos americanos, ocorre de modo generalizado para condições desfavoráveis de crescimento, e também foi especificamente identificada com relação aos ambientes com alta e baixa disponibilidade de N (Duvick, 1984; Duvick, 1997). No progresso genético dos híbridos americanos existe, portanto, uma associação entre a responsividade das linhas ao $\mathrm{N}$, ou a produtividade delas em solos com alta disponibilidade $\mathrm{N}$, com a tolerância à deficiência de $\mathrm{N}$ dos híbridos, uma vez que a seleção de linhas tolerantes a altas doses de $\mathrm{N}$ foi praticada e foram obtidos híbridos mais produtivos em solos com deficiência de N.

A associação entre responsividade de linhas ao $\mathrm{N}$ e responsividade dos seus híbridos ao N está presente também nos trabalhos de Balko \& Russel (1980a) e de Tsai et al. (1991a), pois os híbridos mais responsivos ao $\mathrm{N}$, do trabalho de Tsai et al. (1991a), tiveram como progenitor uma linha avaliada como altamente responsiva no trabalho de Balko \& Russel (1980a), e também o oposto ocorreu, pois os híbridos menos responsivos tiveram progenitores menos responsivos, embora um dos híbridos mais responsivos tenha tido como progenitores, uma linha altamente responsiva e uma não responsiva.

No trabalho de Lafitte \& Edmeades (1995) não existiu associação entre as produtividades de linhas $\mathrm{S}_{3}$, em solos pobres em $\mathrm{N}$, com a produtividade de seus híbridos nos níveis alto e baixo de N. É interessante observar, entretanto, que tanto as linhas mais produtivas quanto as menos produtivas, sob deficiência de $\mathrm{N}$, do trabalho de Lafitte \& Edmeades (1995), mostraram, na média, uma elevada resposta ao N, embora estes contrastes, das linhas entre os níveis de $\mathrm{N}$, não tenham sido submetidos a teste estatístico. Esta observação indica que a responsividade das linhas pode ser 
importante para a formação de híbridos superiores para solos com e sem deficiência de N.

O presente trabalho confirma que a produtividade das linhas sob deficiência de $\mathrm{N}$ não se correlaciona com a superioridade dos híbridos, formados com estas linhas, em solos com e sem deficiência de $\mathrm{N}$, como foi descrito por Lafitte \& Edmeades (1995).

$\mathrm{O}$ presente trabalho oferece indícios da responsividade das linhas ao $\mathrm{N}$ ser importante para a formação de híbridos para solos com e sem deficiência de $\mathrm{N}$, uma vez que as linhas não responsivas ou menos responsivas ao $\mathrm{N}$ tiveram os menores efeitos de CGC nos cultivos com e sem deficiência de $\mathrm{N}$ e a linhas com maior resposta ao $\mathrm{N}$ apresentaram maiores efeitos de CGC nos níveis alto e baixo de $\mathrm{N}$.

Embora a linha 6 não tenha apresentado elevado efeito de CGC para a produtividade, esta linha apresentou o segundo maior efeito de CGC para o número de grãos por planta no nível alto de $\mathrm{N}$, mas esta vantagem foi superada pelo maior efeito de CGC para massa de cem grãos das demais linhas que obtiveram elevados efeitos de CGC para a produtividade no nível alto de N. A linha 6 apresentou também efeito de CGC que indica a mais elevada sincronia no florescimento do grupo, e a associação desta variável com o número de grãos por planta tem sido relatada (Cárcova et al., 2000).

Para o teor de clorofila existiu alguma associação entre as linhas e seus híbridos. As linhas 2 e 6 apresentaram elevados teores e também elevados efeitos de CGC. A linha 4 apresentou valor e efeito de CGC inferiores nesta variável. Entretanto não existiu esta correspondência para a linha 5. Lafitte \& Edmeades (1995) encontraram, para teor de clorofila, elevada associação do valor medido na linha com o seu efeito de CGC e também com a média dos valores dos híbridos contendo a linha. Os efeitos aditivos foram mais importantes do que os não aditivos para o teor de clorofila e isto está de acordo com o encontrado por Baer \& Schrader (1985). Entretanto existiu também significância para a CEC, o que está de acordo com os trabalhos de Baer \& Schrader (1985) e Mehta et al. (1992), os quais encontraram 
heterose e aparente sobredominância, respectivamente, para o teor de clorofila em milho.

Lafitte \& Edmeades (1995) encontraram associação entre o valor medido nas linhas sob baixo $\mathrm{N}$ e os seus efeitos de CGC também sob baixo $\mathrm{N}$, para a sincronia no florescimento. Semelhante associação foi observada no presente estudo para a maioria das linhas. A linha 6 apresentou elevada sincronia e se destacou muito das demais linhas no efeito de CGC desta variável. Para a linha 2 foram obtidos valores que indicam baixa sincronia na linha e no efeito de CGC. Contudo a linha 5 não apresentou este tipo de associação. Os efeitos não aditivos foram mais importantes para prolificidade do que para a sincronia no flroescimento e isto também foi observado por Guei \& Wassom (1992).

As variáveis teor de clorofila e sincronia no florescimento apresentaram correlações residuais significativas com a produtividade de grãos apenas no nível baixo de $\mathrm{N}$ e isto está de acordo com o trabalho de Bänziger \& Lafitte (1997), os quais também observaram que estas variáveis são boas indicadoras da variação ambiental.

A indicação do baixo teor de $\mathrm{N}$ nos grãos ser dominante com relação ao alto teor, e também a correlação negativa entre produtividade de grãos e o teor de $\mathrm{N}$ nos grãos estão de acordo com trabalhos prévios (Bletsos \& Goulas, 1999; Duvick, 1997; Hay et al., 1951). Hay et al. (1953) demonstraram que a maior parte do $\mathrm{N}$ nos grãos se encontra na forma de proteínas. Bletsos \& Goulas (1999) não obtiveram eficência na seleção para aumento das produtividades de grãos e de proteína. Duvick (1997) demonstrou que os incrementos apresentados na produtividade de grãos e no teor de amido, nos híbridos americanos entre 1934 e 1991, foram acompanhados por declíneo no teor de proteína dos grãos. Muchow (1998) demonstrou que a maior eficiência na utilização de $\mathrm{N}$ do milho, em relação ao sorgo, foi associada à maior concentração de $\mathrm{N}$ nos grãos de sorgo.

As linhas e os híbridos apresentaram sensibilidades diferentes ao N. No experimento 2, no qual foram avaliadas as linha e os híbridos, existiu a indicação de controle genético distinto entre os níveis de $\mathrm{N}$, nas linhas, para cinco variáveis, enquanto para os híbridos existiu a indicação da diferença no componente aditivo para 
três variáveis, com apenas uma em comum com as linhas, que foi a produtividade de grãos. Apesar da indicação, em linhas e híbridos, de controle genético distinto entre os níveis de $\mathrm{N}$ para a produtividade de grãos, observou-se falta de associação entre as posições relativas das linhas com os seus efeitos de CGC. Portanto mesmo para a produtividade de grãos existiu diferença, na resposta ao $\mathrm{N}$, entre as linhas e os híbridos. Balko \& Russel (1980a) discutem esta diferença apresentando o fato das linhas mostrarem sinais de deficiência de $\mathrm{N}$ antes dos híbridos cultivados na mesma condição. Contudo, somente a diferença de intensidade na percepção da deficiência de $\mathrm{N}$ não é suficiente para explicar as diferenças observadas entre as linhas e seus híbridos no presente trabalho. Como o componente não aditivo também foi significativo para a maioria das variáveis em pelo menos um nível de $\mathrm{N}$, os efeitos de dominância e epistasia podem ter contribuído para a diferença de expressão entre linhas e híbridos. Outra possibilidade seria de fatores genéticos e fisiológicos independentes daqueles responsáveis pela expressão das variáveis pe se terem grande influência na expressão da tolerância à deficiência de $\mathrm{N}$, tal como foi sugerido por Frova et al. (1999) para a tolerância à seca. Estes autores mostraram que uma grande proporção de alelos que aumentaram a tolerância à seca foi proveniente da linha susceptível e também mostraram que as regiões cromossômicas relacionadas com as respostas à seca dos componentes da produtividade foram diferentes das regiões relacionadas com o controle básico destes componentes.

\subsection{Experimentos de casa de vegetação e em sala de crescimento}

As médias dos híbridos superou as médias das linhas, nos dois níveis de $\mathrm{N}$, para as massas das parte aérea e raiz secas. Giauffret et al. (1997) também encontrou vigor híbrido para a taxa de crescimento da biomassa da parte aérea em estádio semelhante ao observado no presente trabalho, no qual as plantas se encontravam com cerca de 7 folhas. Rahman et al. (1994), trabalhando com linhas progenitoras de híbridos comerciais, encontraram elevada heterose para a massa de raízes secas, e demonstraram que a magnitude relativa dos efeitos de dominância foi maior que a dos efeitos aditivos. Dantas et al. (1997), trabalhando com variedades braquíticas, não 
encontraram heterose para a massa das raízes secas. Neste trabalho de Dantas et al. (1997), entretanto, os híbridos comerciais, usados como controles, apresentaram maior massa das raízes secas do que as variedades e seus cruzamentos.

As linhas apresentaram maior média para o teor de $\mathrm{N}$ que os híbridos no dois níveis de $\mathrm{N}$, e isto significa que os híbridos produziram maior quantidade de matéria seca da parte aérea por unidade de $\mathrm{N}$ presente nestes tecidos. Efeitos significativos de CEC também foram obtidos para a eficiência na tilização do $\mathrm{N}$ nos dois níveis de $\mathrm{N}$ do experimento de campo. Esta eficiência significa maior produção de grãos por unidade de $\mathrm{N}$ presente na parte aérea da planta.

Os híbridos apresentaram, no nível alto de $\mathrm{N}$, média maior que as linhas para a quantidade de $\mathrm{N}$ na parte aérea, o que indica uma maior eficiência na absorção de $\mathrm{N}$. No experimento de campo também existiu significância dos efeitos de CEC para a quantidade de $\mathrm{N}$ total na parte aérea, nos dois níveis de $\mathrm{N}$. Estes resultados concordam com os de Moll et al. (1994) que também observaram heterose para absorção de N.

Os híbridos apresentaram, na média, maior absorção e utilização do $\mathrm{N}$ que as linhas no experimento em casa de vegetação e também no experimento de campo os híbridos apresentaram efeitos não aditivos significantes para estas variáveis. Estes resultados concordam com os de Elings et al. (1997) e de Bertin \& Gallais (2000). A seleção para aumento da absorção e $\mathrm{N}$ em solos com deficiência deste nutriente foi apontada como promissora por Elings et al. (1997). Bertin \& Gallais (2000) observaram que a maior eficiência no uso do $\mathrm{N}$, em solos pobres em $\mathrm{N}$, foi explicada por ambas as eficiências de absorção e de utilização, embora a variação para absorção de $\mathrm{N}$ tenha sido maior no ambiente com deficiência de $\mathrm{N}$, e o oposto tenha ocorrido com a eficiência na utilização. A significância dos efeitos de CGC no presente trabalho também concordam com estas observações de Bertin \& Gallais (2000), pois para o N total só existiu significância no nível alto de $\mathrm{N}$, enquanto a significância foi maior para a eficiência na utilização do $\mathrm{N}$ no nível baixo de $\mathrm{N}$.

A maior absorção de $\mathrm{N}$ dos híbridos pode estar relacionada com a maior quantidade de raízes, como já foi discutido para as linhas. Gastal \& Lemaire (2002) consideram que a absorção de nutrientes depende principalmente da distribuição das 
raízes no solo, pois os sistemas de transporte de nutrientes das raízes são eficientes mesmo quando as concentrações dos nutrientes no solo são muito reduzidas.

O contraste entre híbridos e linhas também revelou menor teor de proteína solúvel nas raízes dos híbridos. Isto indica uma menor eficiência na utilização do $\mathrm{N}$ das linhas também nestes tecidos da planta. Leonardi et al. (1991) estudaram a associação entre as expressões fenotípica e molecular da heterose, demonstrando heranças aditivas e não aditivas para a quantidade de uma determinada proteína. Estes autores demonstraram que a expressão da quantidade de uma proteína pode ser dependente do tecido e do estádio fisiológico, e também encontraram a heteroses positivas e negativas para a quantidade de proteína. No presente trabalho foi feita a mensuração de proteínas solúveis totais e não de proteínas específicas, como no trabalho de Leonardi et al. (1991), e foi possível identificar dominância do menor teor de proteína nas raízes em relação ao maior teor.

A razão $F v / F m$ e a fotossíntese foram significativamente maiores no nível alto do que no nível baixo de $\mathrm{N}$ e isto está de acordo com os trabalhos de Khamis et al. (1990) e de Lu \& Zhang (2000). Khamis et al. (1990) demonstraram a redução da razão $F v / F m$ pela deficiência de $\mathrm{N}$ sob alta irradiância, mas não sob baixa irradiância. Segundo Lu \& Zhang (2000) a maior sensibilidade à fotoinibição, de milho deficiente em N, está associada com aumento do acúmulo de centros de reação do PSII (fotossistema II) inativados, diminuição da capacidade de supressão não fotoquímica e aumento da fração do estado reduzido do aceptor primário de elétrons do PSII, o sítio $Q_{\mathrm{A}}$.

Foi identificada heterose média para a razão $F v / F m$, mas não para a fotossíntese medida como a taxa de assimilação líquida de dióxido de carbono, indicando a maior eficiência das medições relacionadas com a fase fotoquímica do que com a fase bioquímica da fotossíntese, o que concorda com os trabalhos de Earl \&Tollenaar (1999) e Silva et al. (1995). os quais demonstraram a eficiência das medições associadas com a fase fotoquímica da fotossíntese para diferenciar genótipos de milho. Segundo estes autores a maior eficiência destas medições em relação às baseadas nas trocas gasosas, ocorre porque que estas últimas são mais variáveis dentro 
do dossel da planta e também no tempo, pois sofrem mais influência de variáveis ambientais. A técnica usada por Silva et al. (1995) foi a das medições fotoacústicas do oxigênio liberado pela fotossíntese, e estes autores identificaram heterose para esta variável. Earl \& Tollenaar (1999) diferenciaram híbridos comerciais usando medições da fluorescência da clorofila $a$. Heterose positiva foi identificada em duas das três famílias estudadas por Silva et al. (1995), e Krebs et al. (1996) encontrou significância apenas para o componente aditivo, em um dialelo de três linhas de milho, para medições da fluorescência da clorofila $a$. As medições baseadas na fase fotoquímica se apresentam como mais eficientes e são correlacionadas com a fixação de carbono como demonstraram Edwards \& Baker (1993).

Elevados valores de duração da fotossíntese e de área foliar são associados com aumentos da produtividade (Evans \& Fischer, 1999; Richards, 2000). Contudo a fotossíntese por unidade de área foliar, tal como foi mensurada no presente estudo, geralmente não está associada à elevação das produtividades. Richards (1999) relata a ocorrência da quase duplicação da produtividade de grãos dos cereais, durante o século passado, sem que tenha ocorrido mudança na taxa de fotossíntese por unidade de área foliar. Entretanto a interação das heteroses para a taxa de fotossíntese, área foliar e teor de clorofila, entre outros componentes, vem se mostrando promissora na predição da produtividade (Metha \& Sarkar, 1992; Metha et al., 1992).

A atividade da GR medida, nas raízes de milho, espectrofotometricamente apresentou diferença de cerca de até 10 vezes entre os níveis de $\mathrm{N}$, enquanto a intensidade do perfil de isoenzimas sugeriu um aumento menor, pois as amostras do milho cultivado no nível alto de $\mathrm{N}$ apresentaram apenas uma ou duas bandas a mais do que as do nível baixo. Discrepâncias desta natureza são relatadas e Mullineaux \& Creissen (1997) indicam que as alterações nos níveis de isoformas particulares podem ser mais importantes do que as alterações na atividade total da GR, em plantas estressadas. No trabalho de Anderson et al. (1995), por exemplo, a atividade de uma GR citossólica, observada em eletroforese, de plantas estressadas por frio aumentou, sem que existisse troca na atividade total. Neste trabalho (Anderson et al., 1995) o aparecimento de novas isoformas não aumentou a atividade total e no presente trabalho 
o aparecimento de novas isoformas aumentou muito a atividade total, o que está de acordo com a possibilidade de contribuições diferentes das isoformas particulares na atividade total.

Um fenômeno comum entre as raízes de milho, Arabidopsis thaliana e cevada, foi a presença de pelo menos uma isoforma de GR, menos eletropositiva, a mais no nível mais alto de N. Para o nosso conhecimento este fenômeno ainda tinha sido relatado e precisará ser estudado em maior profundidade para o esclarecimento do seu significado. A presença desta banda extra apenas nas raízes mais novas do tratamento de $10 \mathrm{mM}$ de $\mathrm{N}$, que também eram mais grossas, sugere que esta banda pode estar relacionada com o acúmulo de reservas nestas raízes que possuem pouca participação na absorção de nutrientes (McCully, 1999). A revisão de trabalhos recentes permite uma associação plausível entre a maior atividade da GR e síntese de amido. O trabalho de Schindler et al. (2001), por exemplo, mostra que enzimas desramificadoras de amido são ativadas por glutationa reduzida (GSH). Estas enzimas auxiliam na cristalização da amilopectina e são importantes para a síntese de amido. Mutantes de milho, arroz e Chlamydomonas reinhadtii, deficientes nestas enzimas, substituem o acúmulo de amido pelo acúmulo de polímeros relacionados ao glicogênio (Dauvilée et al., 2000). Outra enzima da síntese de amido, a ADP-glicose pirofosforilase (AGPase), é inativada com a dimerização que pode ser revertida com DTT (Tiessen et al., 2002). Estes autores demonstraram que a incubação de fatias de tubérculos de batata com DTT ou elevados níveis de sacarose reduziram a dimerização, aumentaram a ativação da AGPase e estimularam a síntese de amido. A GSH, que é o produto da reação catalisada pela GR, é importante na modulação de atividades enzimáticas, reduzindo pontes de dissulfeto e formando assim grupos sulfidrilas (Mullineaux \& Creissen, 1997), portanto, teoricamente é possível que a AGPase seja assim também modulada. A síntese de amido em raízes de cereais é reportada nos trabalhos de Peng et al. (2001) e Dieuaidenoubhani et al. (1995) e Rontein et al. (2002) demonstraram que a variação nos níveis de glicose causa maior variação na síntese de amido do que em outras vias metabólicas consideradas centrais tais como a glicólise e a via dos ácidos tricarboxílicos. É possível, portanto, supor que a síntese de amido seja também 
alterada pela disponibilidade de $\mathrm{N}$ das plantas, uma vez que esta disponibilidade afeta os níveis de açúcares solúveis das raízes (Alfoldi \& Pinter, 1992). Contudo a associação entre a atividade da GR em raízes de plantas cultivadas com elevada disponibilidade de $\mathrm{N}$ e a síntese de amido terá de ser testada futuramente.

Outras possibilidades de explicação para a elevação da atividade da GR nas raízes poderiam ser relacionadas à toxidez de amônio ou ao aumento do crescimento. Em Anabaena o cultivo com amônio aumentou a atividade da GR em comparação ao cultivo com nitrato ou à fixação de $\mathrm{N}_{2}$ (Jiang et al., 1995). O envolvimento da GR com o metabolismo do nitrogênio não foi esclarecido e Jiang et al. (1995) sugeriram uma possível toxidez de amônio como explicação para os seus resultados. Mullineaux \& Creissen (1997), alternativamente, propuseram uma explicação, para os resultados de Jiang et al. (1995), baseada no estímulo ao crescimento, à fotossíntese e à atividade metabólica que demandam um aumento nos sistemas antioxidantes. A GR participa destes sistemas atuando no ciclo ascorbato-glutationa (Mullineaux \& Creissen, 1997).

O trabalho de Rios-Gonzales et al. (2002) indica que a toxidez de amônio não eleva a atividade da GR em raízes de milho. Neste trabalho as plantas cresceram menos no tratamento com amônio do que no tratamento com nitrato, mas as raízes apresentaram maior atividade da GR no tratamento com nitrato, embora o tratamento com amônio tenha elevado a atividade da GR nas folhas.

Rios-Gonzales et al. (2002) observaram que as partes mais novas das raízes tratadas com nitrato apresentaram maior atividade de GR que as partes maduras. Isto também pode indicar que o crescimento maior destes tecidos demanda aumento na GR, atuando como antioxidante, tal como sugeriram Mullineaux \& Creissen (1997). com relação ao trabalho de Anabaena acima citado. O efeito do amônio, reduzindo o crescimento e a atividade da GR das raízes (Rios-Gonzales et al., 2002), também concorda com a relação entre maior crescimento e maior atividade da GR.

A relação causal entre o crescimento e a atividade da GR pode ocorrer em duas direções. Na primeira, o crescimento gera espécies tóxicas e a GR seria aumentada para conferir proteção (Mullineaux \& Creissen, 1997). Uma outra relação é a do elevado nível de GSH, ou da elevada razão entre glutationa reduzida e oxidada 
(GSH/GSSG), modular o desenvolvimento e o crescimento, tal como foi demostrado por Sánchez-Fernández et al. (1997) para meristemas apicais de raízes. Estes autores apresentaram três evidências para a participação da GSH na regulação da divisão celular no meristema primário de raízes de Arabidopsis thaliana: primeira, aumento artificial do nível endógeno de GSH estimulou divisão celular; segunda, diminuição artificial dos níveis de GSH reduziu as divisões celulares; e terceira, elevados níveis de GSH endógeno são associados com células iniciando divisões, mas não com as células do centro quiescente.

A influência da disponibilidade de $\mathrm{N}$ na SOD e CAT também precisará ser esclarecida futuramente. Estas enzimas estão fortemente associadas com a proteção contra espécies tóxicas de oxigênio e uma das principais fontes destas espécies, em tecidos heterotróficos, é a cadeia de transporte de elétrons da fosforilação oxidativa (Niyogi, 1999). As raízes de milho do nível alto de $\mathrm{N}$ apresentaram maior crescimento e assim podem ter apresentado maior respiração, e isto poderia explicar a tendência de maior atividade da catalase. Contudo a alta atividade em raízes de cevada no menor nível de $\mathrm{N}$ contraria esta explicação. Esta alta atividade poderia, por outro lado, estar associada ao aumento da senescência, uma vez que a condição de extrema deficiência de $\mathrm{N}$ poderia desencadear este processo, e a catalase pode apresentar aumento de atividade em tecidos senescentes (Acevedo \& Scandalios, 1996). Inclusive neste trabalho de Acevedo \& Scandalios (1996), ocorreu a elevação da atividade da catalase, em estilos de milho senescentes, sem a ocorrência de alteração na atividade da superóxido dismutase, tal como ocorreu nas raízes de cevada, do presente trabalho, no menor nível de $\mathrm{N}$. 


\section{CONCLUSÕES}

1 - As variáveis produtividade de grãos, teor de clorofila, massa de cem grãos; prolificidade, sincronia no florescimento e teor de $\mathrm{N}$ nos grãos apresentaram, nas linhas de milho, controle genético distinto nos diferentes níveis de $\mathrm{N}$.

2 - As variáveis produtividade de grãos, número de grão por planta e teor de clorofila apresentaram, nos híbridos de milho, controle genético aditivo distinto nos diferentes níveis de $\mathrm{N}$.

3 - Não houve associação entre a produtividade de grãos das linhas e seus efeitos de CGC para esta variável, nos níveis alto e baixo de N.

4 - Existiu associação da sensibilidade da produtividade de grãos ao $\mathrm{N}$ das linhas com os seus efeitos de CGC para esta variável nos níveis alto e baixo de $\mathrm{N}$, uma vez que as linhas que sofreram os maiores efeitos das doses de $\mathrm{N}$ foram as de maior efeito de CGC, enquanto as linhas que sofreram os menores efeitos das doses de $\mathrm{N}$ apresentaram os menores efeitos de CGC, indicando que esta característica das linhas deve ser considerada nos programas de melhoramento para solos pobres em N.

5 - As plantas avaliadas em casa de vegetação com 32 dias após a germinação, apresentaram heterose média para absorção e utilização de $\mathrm{N}$, indicando a possibilidade de seleção precoce para estas variáveis, as quais também apresentaram significância para os efeitos não aditivos no experimento de campo.

6 - Foi detectada heterose média para a razão Fv/Fm mas não para a fotossíntese indicando a maior eficiência das medidas associadas à fluorescência da clorofila em relação àquelas associadas com a fixação de carbono. 
7 - A deficiência de $\mathrm{N}$ reduziu o número de isoenzimas da glutationa redutase nas raízes de milho, cevada e Arabidopsis thaliana, indicando que este pode ser um fenômeno genérico que merece ser estudado em maior profundidade. 


\section{REFERÊNCIAS BIBLIOGRÁFICAS}

ACEVEDO, A.; SCANDALIOS, S.G. Antioxidant gene (Cat/Sod) expression dring the process of accelerated senescence in silks of the maize ear shoot. Plant Physiology and Biochemistry, v.34, n.4, p.539-545, 1996.

AGRAMA, H.A.S.; ZAKARIA, A.G.; SAID, F.B.; TUINSTRA, M. Identification of quantitative trait loci for nitrogen use efficiency in maize. Molecular Breeding, v.5, n.2, p.187-195, 1999.

ALFOLDI, Z; PINTER, L. Accumulation and partioning of biomass and soluble carbohydrates in maize seedlings as affected by source of nitrogen, nitrogen concentration, and cultivar. Journal of Plant Nutrition, v.15, n.11, p.2567-2583, 1992.

ANDERSON, M.D.; PRASAD, T.K.; STEWART, C.R. Changes in isozyme profiles of catalase, peroxidase, e glutathione reductase during acclimation to chilling in mesocotyls of maize seedlings. Plant Physiology, v.109, n.4, p.1247-1257, 1995.

AZEVEDO, R.A.; ALAS, R.M.; SMITH, R.J.; LEA, P.J. Response of antioxidant enzymes to transfer from elevated carbon dioxide to air and ozone fumigationn, in the leaves and roots of wild-tipe and a catalase-deficient mutant of barley. Physiologia Plantarum, v.104, n.2, p.280-292, 1998.

BAER, G.R.; SCHRADER, L.E. Inheritance of DNA concentration, and celular contents of soluble protein, chlorophyll, ribulose bisphosphate carboxylase, and pyruvate pi dikinase activity in maize leaves. Crop Science, v.25, n.6, p.916-923, 1985.

BAKER, R.J. Issues in diallel analysis. Crop Science, v.18, n.4, p.533-536, 1978. 
BALKO, L.G.; RUSSEL, W.A. Effects of rates of nitrogen fertilizer on maize inbred lines and hybrid progeny. II. Correlations among agronomic traits. Maydica, v.25, n.2, p.81-94, 1980a.

BALKO, L.G.; RUSSEL, W.A. Response of maize imbred lines to $\mathrm{N}$ fertilizer. Agronomy Journal, v.72, n.5, p.723-728, 1980 b.

BÄNZIGER, M.; LAFITTE, H.R. Efficiency of secundary traits for improving maize for low - nitorgen target environments. Crop Science, v.37, n.4, p.1110-1117, 1997.

BÄNZIGER, M.; LAFITTE, H.R.; EDMEADS, G.O. Intergenotypic competition during evaluation of maize progenies under limited and adequat $n$ supply. Field Crops Research, v.44, n.1, p.25-31, 1995.

BECHTOLD, U.; PAHLICH, E.; LEA, P.J. Methionine sulphoximine does not inhibit pea and wheat glutamate dehydrogenase. Phytochemistry, v.49, n.2, p.347-354, 1998.

BERTIN, P.; GALLAIS, A. Genetic variation for nitrogen use efficiency in a set of recombinant maize imbred lines I. Agrophysiological results. Maydica, v.45, n.1, p.53-66, 2000.

BLETSOS, E.A.; GOULAS, C.K. Mass selection for improvement of grain yield and protein in a maize population. Crop Science, v.39, n.5, p.1302-1305, 1999.

BRADFORD, M.M. A rapid and sensitive method for the quantitation of microgram quantities of proteinutilizing the principle of protein-dye binding. Analytical Biochemistry, v.72, p.248-254, 1976.

BRUGIÈRE, N.; DUPOIS, F.; LIMAMI, A.M.; LELANDAIS, M.; ROUX, Y.; SANGWAN, R.S.; HIREL, B. Glutamine shynthetase in the phloem plays a major role in controlling proline production. The Plant Cell, v.11, n.10, p.1995$2011,1999$.

CÁRCOVA, J.; URIBELARREA, M.; BORRÁS, L.; OTEGUI, M.E.; WESTGATE, M.E. Synchronous pollination within and between ears improve kernel set in maize. Crop Science, v.40, n.4, p.1056-1061, 2000. 
CECCARELLI, S. Adatation to low/high imput cultivation. Euphytica, v.92, n.1-2, p.203-214, 1996.

CHOI, Y.A.; KIM, S.G.;KNOW, Y.M. The plastidic glutamine synthetase is directly modulated by means of redox change at two unique cysteine residues. Plant Science, v.149, n.2, p.175-182, 1999.

CHRISTIANSEN-WENIGER, C. Endophytic establishment of diazotrophic bacteria in auxin-induced tumors of cereal crops. Critical Reviews in Plant Sciences, v.17, n.1, p.55-76, 1998.

CLARK, R.B.; DUNCAN, R.R. Improvement of plant mineral nutrition through breeding. Field Crops Research, v.27, n.3, p.219-240, 1991.

CREN, M.; HIREL, B. Glutamine synthetase in higher plants: regulation of gene and protein expression from teh organ to the cell. Plant Cell Physiol, v.40, n.12, p.1187-1193, 1999.

DANTAS, A.C.V.; MIRANDA FILHO, J.B.; ALLEONI, M.R.B. Diallel cross analysis for young plants of brachytic maize (Zea mays L.) varieties. Brazilian Journal of Genetics, v.20, n.3, p.453-458, 1997.

DAUVIllÉ, D.; MESTRE, V.; COLlEONI, C.; SLOMIANNY, M.C.; MOUILLE, G.; DELRUE, B.; D’HULST, C.; BLIARD, C.; NUZILLARD, J.M.; BALL, S. The debranching enzyme complex missing in glycogen accumulation mutants of Chlamydomonas reihardtii displays na isoamylase-type specifificity. Plant Science, v.157, n.2, p.145-156, 2000.

DEL-LONGO, O.T.; GONZALEZ, C.A.; PASTORI, G.M.; TRIPPI, V.S. Antioxidant defenses under hyperoxygenic and hyperosmotic conditions in leaves of 2 lines of maize with diferential sensitivity to drought. Plant and Cell Physiology, v.34, n.7, p.1023-1028.

DIEUAIDENOUBHANI, M.; RAFFARD, G.; CANIONI, P.; PRADET, A.; RAYMOND, P. Quantification of compartmented metabolic fluxes in maize roottips using isotope distribution from C-13-labeled or C-14-labled glucose. Journal of Biological Chemistry, v.270, n.22, p.13147-13159, 1995. 
DUVICK, D.N. Genetic contributions to advances in yield of U.S. maize. Maydica, v.37, n.1, p.69-79, 1992.

DUVICK, D.N. Genetic contributions to yield grains of U.S. hybrid maize,1930 to 1980. In: FEHR, W. (Ed.). Genetic contribuition to yield gains of five major crop plants. Madison: Crop Science Society of America, 1984. cap.2, p.15-47. (CSSA special pub.,7)

DUVICK, D.N. What is yield ? In: EDMEADES, G.O.; BÄNZIGER, M.; MICKELSON, H.R.; PEÑA-VALDIVIA， C.B. (Ed.). DEVELOPING DROUGHT- AND LOW N-TOLERANT MAIZE, El Batán, Mexico, 1996. Proceedings of a symposium. México: CIMMYT, 1997. p.332-335.

DWYER, L.M.; ANDERSON, A.M.; STEWART, D.W.; MA, B.L.; TOLLENAAR, M. Changes in maize hybrid photosynthetic response to leaf nitrogen, from preanthesis to grain fill. Agonomy Journal, v.87, n.6, p.1221-1225, 1995.

EARL, H.J.; TOLLENAAR, M. Using chlorophyll fluorometer to compare photosynthetic performance of commercial maize (Zea mays L.). Field Crops Research, v.61, n.3, p.201-210, 1999.

EDWARDS, G.E.; BAKER, N.R. Can $\mathrm{CO}_{2}$ assimilação in maize leaves be predicted accurately from chlorophyll fluorescence analysis ? Photosynthesis Research, v.37, n.2, p.89-102, 1993.

EICHELBERGER, K.D.; LAMBERT, R.J.; BELOW， F.E.; HAGEMAN， R.H. Divergent phenotypic recurrent selection for nitrate reductase activity in maize. I. Selection and correlated responses. Crop Science, v.29, n.6, p.1393-1397,1989.

ELINGS, A.; WHITE, J.W.; EDMEADES, G.O. Options for breeding for greater maize yields in the tropics. European Journal of Agronomy, v.7, n.1-3, p.119132, 1997.

EVANS, L.T.; FISCHER, R.A. Yield potential: Its definition, measurement, and significance. Crop Science, v.39, n.6, p.1544-1551, 1999.

FEIL, B.; THIRAPORN, R.; STAMP, P. In vitro nitrate reductase activity of laboratory-grown seedlings as na indirect selection criterion for maize. Crop Science, v.33, n.6, p.1280-1286, 1993. 
FERNANDÉZ, J.E.; MURILLO, J.M.; MORENO, F.; CABRERA, F.; FERNANDÉZBOY, E. Reducing fertilization for maize in southwest sapin. Communications in Soil Science and Plant Analysis, v.29, n.19-20, p.2829-2840, 1998.

FISCHER, K.S.; JOHNSON, E.C.; EDMEADS, G.O. Breeding and selection for drought in tropical maize. Mexico: CIMMYT, 1983.

FOX, R.H. Selection for phosphorus efficiency in corn. Communications in Soil Science and Plant Analysis, v.9, n.1, p.13-37, 1978.

FROVA, C.; KRAJEWSKI, P.; DI FONZO, N; VILlA, M.; SARI-GORLA, M. Genetic analysis of drought tolerance in maize by molecular markers I. Yield components. Theoretical and Applied Genetic, v.99, n.1-2, p.280-288, 1999.

GALlARDO, F.; FU, J.; CANTÓN, F.R.; GARCIA-GUTIÉRREZ, A.; CÁNOVAS, F.M.; KIRBY, E.G. Expression of a conifer glutamine synthetase gene in transgenic poplar. Planta, v.210, n.1, p.19-26, 1999.

GASTAL, F.; LEMAIRE, G. N uptake and distribuition in crops: na agronomical and ecophysiological perspective. Journal of Experimental Botany, v.53, n.370, p.789-799, 2002.

GIAUFFRET, C.; BONHOMME, R.; DERIEUX, M. Heterosis in maize for biomass production, leaf area establishment, and radiation use efficiency under cool, spring conditions. Maydica, v.42, n.1, p.13-19, 1997.

GREENWOOD, D.J.; NEETESON, J.J.; DRAYCOTT, A. Quantitative relationships for dependence of the growth rate of arable crops on their nitrogen content, dry weight and aerial environment. Plant Soil, v.91, n.3, p.281-301, 1986.

GUEI, R.G.; WASSOM, C.E. Inheritance of some drought adaptative traits in maize: I Interrelationships between yield, flowering, and ears per plant. Maydica, v.37, n.2, p.157-164, 1992.

HARPER, J.E.; HAGMAN, R.H. Canopy and seasonal profiles of Nitrate Reductase in Soybeans (Glycine max (L.) Merr). Plant Physiology, v.49, n.2, p.146-154, 1972. 
HAY, R.E.; EARLEY, E.B.; DeTURK, E.E. Concentration and translocation of nitrogen compounds in the corn plant (Zea mays). Plant Physiology, v.28, n.4, p.606-621, 1953.

HIREL, B.; BERTIN, P.; QUILLERÉ, I.; BOURDONCLE, W.; ATTAGNANT, C.; DELlay, C.; GOUY, A.; CADIOU, S.; RETAILliAU, C.; FALQUE, M.; GALLAIS, A. Towards a better undestanding of the genetic and physiological basis for nitrogen use efficiency in maize. Plant Physiology, v.125, n.3, p.12581270, 2001.

JAMES, E.K.; OLIVARES, F.L. Infection and colonization of sugar cane and other graminaceous plants by endophytic diazotrophs. Critical Reviews in Plant Sciences, v.17, n.1, p.77-119, 1998.

JIANG, F.; HELLMAN, U.; SROGA, G.E.; BERGMAN, B.; MANNERVIK, B. Cloning, sequencing, and regulation of the glutathione reductase gene from the cyanobacterium Anabaena PCC 7120. Journal of Biological Chemistry, v.270, p.22882-22889, 1995.

KHAMIS, S.; LAMAZE, T.; LEMOINE, Y.; FOYER, C. Adaptation of the photosynthetic apparatus in maize leaves as a result of nitrogen limitation. Plant Phisiology, v.94, n.3, p.1436-1443, 1990.

KINIRY, J.R.; WOOD, C.A.; SPANEL, D.A.; BOCKHOLT, A.J. Seed weight response to decreased seed number in maize. Agronomy Journal, v.54, n.1, p.98$102,1990$.

KLING, J.G.; OIKEH, S.O.; AKINTOYE, H.A.; HEUBERGER, H.T.; HORST, W.J. Potential for developing nitrogen use efficient maize for low imput agricultural systems in the moist savanas of Africa. In: EDMEADES, G.O.; BÄNZIGER, M.; MICKELSON, H.R.; PEÑA-VALDIVIA， C.B. (Ed.). DEVELOPING DROUGHT- AND LOW N-TOLERANT MAIZE, El Batán, Mexico, 1996. Proceedings of a symposium. México: CIMMYT, 1997. p.490-501.

KRAUS, T.E.; EVANS, R.C.; FLETCHER, R.A.; PAUL, S.K.P. Paclobutrazol enhances tolerances to increased levels of UV-B radiation in soybean (Glycine max) seedlings. Canadian Journal Botany, v.73, n.6, p.797-806, 1995. 
KREBS, D.; SYNKOVA, H.; AVRATOVSCUKOVA, N.; KOCOVA, M.; SESTAK, Z. Chlorophyll fluorescence measurements for genetic analysis of maize cultivars. Photosynthetica, v.32, n.4, p.595-608, 1996.

KRONE, T.L.; LAMBERT, R.J. Maize genotypes developed at three soil nitrogen levels I. Inbred evaluation. Maydica, v.40, n.3, p.211-215, 1995a.

KRONE, T.L.; LAMBERT, R.J. Maize genotypes developed at three soil nitrogen levels II. Hybrid evaluation. Maydica, v.40, n.3, p.217-222, 1995 b.

KUMAR, K.; GOH, K.M. Crop residues and management pratices: effects on soil quality, soil nitrogen dynamics, crop yield, and nitrogen recovery. Advances in Agronomy, v.68, p.197-319, 2000.

LAFITTE, H.R.; EDMEADES, G.O. Association between traits in tropical maize lines and their hybrids under high and low soil nitrogen. Maydica, v.40, n.3, p.259-267, 1995.

LAFITTE, H.R.; EDMEADES, G.O. Improvement for tolerance to low nitrogen in tropical maize II. Grain yield, biomass production, and $\mathrm{N}$ accumulation. Field Crops Research, v.39, n.1, p.15-25, 1994a.

LAFITTE, H.R.; EDMEADES, G.O. Improvement for tolerance to low soil nitrogen in tropical maize I. Selection criteria. Field Crops Research, v.39, n.1, p.1-14, 1994b.

LAFITTE, H.R.; EDMEADES, G.O. Improvement for tolerance to low nitrogen in tropical maize III. Variation in yeld across environments. Field Crops Research, v.39, n.1, p.27-38, 1994c.

LAFITTE, H.R.; EDMEADES, G.O.; TABA, S. Adaptative strategies identified among tropical maize landraces for nitrogen-limited environments. Field Crops Research, v.49, n.2-3, p.187-204, 1997.

LAM, H.M.; COSCHIGANO, K.; SCHULTZ, C.; MELO-OLIVEIRA, R.; TJADEN, G.; OLIVEIRA, I.; NGAI, N.; HSIEH, M.-H.; CORUZZI, G. Use of Arabidopsis mutants and genes to study amide amino acid biosynthesis. Plant Cell, v.7, n.7, p.887-898, 1995.

LARCHER, W. Physiological plant ecology. Berlin: Springer-Verlag, 1995. 506p. 
LEA, P.J.; MIFLIN, B.J. Alternative route for nirtrogen assimilation in higher plants. Nature, v.251, n.5476, p.614-616, 1974.

LEA, P.J.; MOROT-GAUDRY, J.-F. (Ed.). Plant nitrogen Berlin: Springer, 2001. $407 \mathrm{p}$.

LEE, D.H.; LEE, C.B. Chilling stress-induced changes of antioxidant enzymes in the leaves of cucumber: in gel enzyme activity assays. Plant Sciences, v.159, n.1, p.75-85, 2000.

LEONARDI, A.; DAMERVAL, C.; VIENNE, D. Hétérosis pour l'expression génétique au cours du développement. In: PICARD, D. (Ed.). Physiologie et production du mais. Paris: INRA, 1991. cap.2, p.175-182.

LIANG, B.C.; MacKENZIE, A.F. Corn yeld, nitrogen uptake and nitrogen use efficiency as influenced by nitrogen fertilization. Canadian Journal of Soil Science, v.74, n.2, p.235-240, 1994.

LU, C.; ZHANG, J. Photosynthetic CO2, chlorophyll fluorescence and photoinhibition as affected by notrogen deficiency in maize plants. Plant Sciences, v.151, p.135-143, 2000.

MA, B.L.; DWYER, L.M. Nitrogen uptake and use of the two contrasting maize hibrids differing in leaf senescence. Plant and Soil, v.199, n.2, p.283-291, 1998.

MACHADO, A.T. Perspectiva do melhoramento genético em milho (Zea mays L.) visando eficiência no uso do nitrogênio. Rio de Janeiro, 1997. 219p. Tese (Doutorado) - Univesidade Federal do Rio de Janeiro.

MACHADO, A.T.; PEREIRA, M.B.; PEREIRA, M.E.; MACHADO, C.T.T.; MEDICI, L.O. Avaliação de variedades locais e melhoradas de milho em diversas regiões do Brasil. In: SOARES, A.C.; MACHADO, A.T.; SILVA, B.M.; VON DER WEID, J.M. (Org.). Milho crioulo: conservação e uso da biodiversidade. Rio de Janeiro: AS-PTA, 1998. cap.4, p.93-106. 
MAJEROWICZ, N.; PEREIRA, J.M.S.; MEDICI, L.O.; BISON, O.; PEREIRA, M.B.; MOREIRA JÚNIOR, U. Estudo da eficiência de uso do nitrogênio em variedades locais e melhoradas de milho. Revista Brasileira de Botânica, v.25, p.129-136, 2002.

MARSCHNER, H. Mineral nutrition of higher plants. London: Academic Press, 1995. 889p.

MATSON, P.A.; NAYLOR, R.; ORTIZ-MONASTERIO, I. Integration of environmental, agronomic, and economic aspects of fertilizer management. Science, v.280, n.5360, p.112-115, 1998.

MCCUllOUGH, D.E.; AGUILERA, A.; TOLLENAAR, M.N. Uptake, partioning, and photosynthetic $\mathrm{N}$-use efficiency of na old and a new maize hybrid. Canadian Journal of Plant Science, v.74, n.3, p.479-484, 1994a.

MCCUllOUGH, D.E.; GIRARDIN, P.H.; MIHAJlOVIC, M.; AGUILERA, A.; TOLLENAAR, M. Infuence of $\mathrm{N}$ supply on development and dry matter accumulation of old and a new maize hibrid. Canadian Journal of Plant Science, v.74, n.3, p.471-474, $1994 b$.

MCCULLY, M.E. Roots in soil: unearthing the complexities of roots and their rhizospheres. Annual Review of Plant Physiology and Plant Molecular Biology, v.50, p.695-718, 1999.

MCKNIGHT, G.M.; DUNCAN, C.W.; LEIFERT, C.; GOLDEN, M.H. Dietary nitrate en man: friend or foe ? British Journal of Nutrition, v.81, n.5, p.349-358, 1999.

MCNALLY, S.F.; HIREL, B.; GADAL, P.; MANN, A.F.; STEWART, G.R. Glutamine synthetases of higher plants. Plant Physiolology, v.72, n.1, p.22-25, 1983.

MEHNER, T.; BENDORF, J. Eutrophication: a summary of observed effects and possible solutions. Journal of Water Supply Research and Technology-Aqua, V.43, n.1, p.35-44, 1995.

MEHTA, H.; SARKAR, K.R. Heterosis for leaf photosynthesis, grain yield and yield components in maize. Euphytica, v.61, n.2, p.161-168, 1992. 
MEHTA, H.; SARKAR, K.R.; SHARMA, S.K. Genetic analysis of photosynthesis and productivity in corn. Theoretical and Applied Genetic, v.84, n.1-2, p.242$255,1992$.

MOLL, R.H.; JACKSON, W.A.; MIKKELSEN, R.L. Recurrent selection for maize yield: dry matter and nitrogen accumulation and partitioning changes. Crop Science, v.34, n.4, p.874-881, 1994.

MOLL, R.H.; KAMPRATH, E.J.; JACKSON, W.A. Analysis and interpretation of factors which contribute to efficiency of nitrogen utilization. Agronomy Journal, v.74, n.3, p.562-564, 1982.

MOLL, R.H.; KAMPRATH, E.J.; JACKSON, W.A. Development of nitrogenefficient prolific hybrids of maize. Crop Science, v.27, n.2, p.181-185, 1987.

MUCHOW, R.C. Nitrogen utilization efficiency in maize and grain sorghum. Field Crops Research, v.56, n.1-2, p.209-216, 1998.

MULLIENEAUX, P.M.; CREISSEN, G.P. Glutathione reductase: regulation and role in oxidative stress. In : SCANDALIOS, J.G. (Ed.). Oxidative stress and the molecular biology of antioxidant defenses. New York: Cold Spring Harbor Laboratory Press, 1997. cap.20, p.667-713.

MURULI, B.I.; PAULSEN, G.M. Improvement of nitrogen use efficiency and its relationship to other traits in maize. Maydica, v.26, n.2, p.63-73, 1981.

NICHOLAS, J.C.; HARPER, J.E.; HAGEMAN, R.H. Nitrate redutase in Soybeans(Glycine max (L.) Mer,) I. Effects of light and temperature. Plant Physiology, v.58, n.6, p.731-735, 1976.

NIYOGI, K.K. Photoprotection revisited: genetic and molecular approaches. Annual Review of Plant Physiology and Plant Molecular Biology, v.50, p.333-359, 1999.

OSUJI, G.O.; REYES, J.C.; MANGAROO, A.S. Glutamate dehydrogenase isomerization: a simple method for diagnosing nitrogen, phosphorus, and potassium sufficiency in maize (Zea mays L.). Journal of Agriculture and Food Chemistry, v.46, n.6, p.2395-2401, 1998. 
PENG, M.; HUCL, P.; CHIBBAR, R.N. Isolation, characterization and expression analysis of starch synthase I from wheat (Triticum aestivum L.). Plant Science, v.161, p.1055-1062, 2001.

PINTER, L.; DEBRECZENI, K.; BURUCS, Z.; FISCHL, K.; ALFOLDI, Z. Evaluation of the different $\mathrm{N}$-sensitivity of two model hybrids for maize. Novenytermeles, v.44, n.4, p.313-322, 1995.

POLLMER, W.G.; EBERHARD, D.; KLEIN, D.; DHILLON, B.S. Genetic control of nitrogen uptake and translocation in maize. Crop Science, v.19, n.1, p.82-86, 1979.

PURCINO, A.A.C.; ARELLANO, C.; ATHWAL, G.S.; HUBER, S.C. Nitrate effect on carbono and nitrogen assimilating enzymes of maize hybrids represeting seven eras of breeding. Maydica, v.43, p.2, p.83-94, 1998.

PURCINO, A.A.C.; MAGNAVACA, R.; MACHADO, A.T.; MARRIEL, I.E.; MAGALHÃES, J.R. Nitrato redutase em genótipos antigos e modernos de milho. In: SIMPÓSIO BRASILEIRO SOBRE NITROGÊNIO EM PLANTAS, 1., Seropédica, 1990. Seropédica: UFRRJ, Imprensa Universitária, 1990. p.491-492.

RAHMAN, H.; WICKS, Z.W.; SWATI, M.S.; AHMED, K. Generation mean analysis of seedling root characteristics in maize (Zea mays L.). Maydica, v.39, n.3, p.177-181, 1994.

RAUN, W.R.; JOHNSON, G.V. Improving nitrogen efficiency for cereal production. Agronomy Journal, v.91, n.3, p.357-363, 1999.

REDINBAUGH, M.G.; CAMPBELL, W.H. Glutamine synthetase and ferridoxindependent glutamate synthase expression in the maize (Zea mays) root primary response to nitrate. Plant Physiology, v.101, n.4, p.1249-1255, 1993.

REGGIANI, R.; AURISANO, N.; MATTANA, M.; BERTANI, A. Genotypic variation and relationship among nitrogen assimilation traits in Zea mays. Revista Brasileira de Fisiologia Vegetal, v.11, n.3, p.123-128, 1999.

RICHARDS, R.A. Selectable traits to increase crop photosynthesis and yield of grain crops. Journal of Experimental Botany, v.51, p.447-458, 2000. 
RIOS-GONZALEZ, K.; ERDEI, L.; LIPS, S.H. The activity of antioxidant enzymes in maize and sunflower seedlings as affected by salinity and different nitrogen sources. Plant Science, v.162, n.6, p.923-930, 2002.

RIZZI, E.; BALCONI, I.; NEMBRINI, F.M.; STEFANINI, F.; COPPOLINO, F.; MOTTO, M. Genetic variation and relationships among n-related traits in maize. Maydica, v.38, n.1, p.23-30, 1993.

RONTEIN, D.; DIEUAIDE-NOUBHANI, M.; DUFOURC, E.J.; RAYMOND, P.; ROLIN, D. The metabolic architecture of plant cells: stability of central metabolism and flexibility of anabolic pathways during the growth cycle of tomato cells. Journal of Biological Chemistry, v.277, n.46, p.43948-43960, 2002.

ROSIELLE, A.A.; HAMBLIN, J. Theorehical aspects of selection for yield in stress and nom-stress environments. Crop Science, v.21, n.1, p.943-946, 1981.

SÁNCHEZ-FERNÁNDEZ, R.; FRICKER, M.; CORBEN, L.B.; WHITE, N.S.; SHEARD, N.; LEAVER, C.J.; MONTAGU, M.V.; INZÉ, D.; MAY, M.J. Cell proliferation and hair tip growth in the Arabidopsis root are under mechanistically different forms of redox control. Proceedings of the National Academy of Science of The United States of America, v.94, n.6, p.2745-2750, 1997.

SANTOS, M.X. dos; GUIMARÃES, P.E.O.; PACHECO, C.A.P.; FRANÇA, G.E.; PARENTONI, S.N.; GAMA, E.E.G. e; LOPES, M.A. Melhoramento intrapopulacional no Sintético Elite NT para solos pobres em nitrogênio. Pesquisa Agropecuária Brasileira, v.33, n.1, p.55-61, 1998

SARI-GORLA, M.; KRAJEWSKI, P.; DI FONZO, N.; VILLA, M.; FROVA, C. Genetic analysis of drought tolerance in maize by molecular markers. II Plant height and flowring. Theoretical and Applied Genetic, v.99, n.1-2, p.289-295, 1999.

SCHINDLER, I.; RENZ, A.; SCHMID, F.X.; BECK, E. Activation of spinach pullulanase by reduction results in a decrease in the number of isomeric forms. Biochimica et Biophysica Acta-Protein Struture and Molecular Enzymology, v.1548, n.2, p.175-186, 2001. 
SIDDIQI, M.Y.; GLASS, A.D.M. Utilization index: a modified approach to the estimation and comparison of nutrient utilization efficiency in plants. Journal of Plant Nutrition, v.4, n.3, p.289-302, 1981.

SILVA, W.J. da; PRIOLI, L.M.; MAGALHÃES, A.C.N.; PEREIRA, A.C.; VARGAS, H.; MANSANARES, A.M.; CELLA, N.; MIRANDA, L.C.M.; ALVARADOGIL, J. Photosynthetic $\mathrm{O}_{2}$ evolution in maize inbreds and their hybrids can differentiated by open photoacustic cell technique. Plant Science, v.104, n.2, p.177-181, 1995.

SINGH, R.P.; JAIWAL, P.K. Manipulation of ammonia assimilation im improvement of nitrogen use efficiency. Current Science, v.77, n.3, p.324-325, 1999.

SMART, C.M. Gene expression during leaf senescence. New Phytology, v.126, n.3, p.419-448, 1994.

SMITH, I.K.; VIERHELLER, T.L.; THORNE, C.A. Assay of glutathione reductase in crude tissue-homogenates, using 5.5' DITHIOBIS (2-nitrobenzoic acid). Annalytical Biochemistry, v.175, n.2, p.408-413, 1988.

TEMPLE, S.J.; VANCE, C.P.; GANTT, J.S. Glutamate synthase and nitrogen assimilation. Trends in Plant Science, v.3, n.2, p.51-56, 1998.

TIESSEN, A.; HENDRIKS, J.H.M.; STITT, M.; BRANSCHEID, A.; GIBON, Y.; FARRE, E.M.; GEIGENBERGER, P. Starch synthesis in potato tubers is regulated by post-translational redox modification of ADP-glucose pyrophosphorylase: a novel regulatory mechanism linking starch synthesis to the sucrose supply. Plant Cell, v.14, n.9, p.2191-2213, 2002.

TSAI, C.L.; HUBER, D.M.; WARREN, H.L.; LYZNIK, A. Nitrogen uptake and redistribution during maturation of maize hybrids. Journal of Food and Agriculture Science, v.57, p.175-187, 1991a.

TSAI, C.L.; HUBER, D.M.; WARREN, H.L.; TSAI C, Y. Effects of cross-pollination dry matter accumulation, nutrient partioning and grain yield of maize hybrids grown under different levels of fertility. Journal of Food and Agriculture Science, v.57, n.2, p.163-174, 1991 b. 
UHART, S.A.; ANDRADE, F.H. Nitrogen and carbon accumulation and remobilization during grain filling in maize under diferent source/sink ratios. Crop Science, v.35, n.1, p.183-190, 1995.

ZAHARAH, A.R.; BAH, A.R.; MWANGE, N.K.; KATHULI, P.; JUMA, P. Managemnet of gliricidia (Gliricidia sepium) residues for improved sweet corn yield in na ultisol. Nutrient Cycling in Agroecosystems, v.54, n.1, p.31-39, 1999. 